\title{
From Independence to Politics in Financial Regulation
}

\author{
Stavros Gadinis*
}

Independent agencies have long dominated the institutional structure of financial regulation. But after the 2007-08 crisis, this Article argues, the independent agency paradigm is under attack. To monitor financial institutions more thoroughly and address future failures more effectively, the United States and other industrialized nations redesigned the framework of financial regulation. Post-2008 laws allocate new powers not to independent bureaucrats, but to elected politicians and their direct appointees.

To document this global paradigm shift, the Article examines the laws of fifteen key jurisdictions for international banking: the United States, the United Kingdom, France, Germany, Japan, Spain, Switzerland, Belgium, Ireland, Italy, Denmark, Canada, Australia, Mexico, and South Korea. This analysis points to a marked increase in the influence of elected politicians over banking. Politicians' new powers extend not only over emergencies, but also over financial institutions' regular operations. Politicians are now at the helm of innovative institutional arrangements, typically in the form of regulatory councils that encompass preexisting independent

Copyright (C) 2013 California Law Review, Inc. California Law Review, Inc. (CLR) is a California nonprofit corporation. CLR and the authors are solely responsible for the content of their publications.

* Assistant Professor of Law, University of California, Berkeley, School of Law. I would like to thank Michelle Anderson, John Armour, Ken Bamberger, Robert Bartlett, Lucian Bebchuk, Eric Biber, Bob Cooter, Chris Brummer, Dick Buxbaum, Jens Dammann, Dan Farber, Anna Gelpern, Erik Gerding, Jake Gersen, Jack Goldsmith, Andrew Guzman, Gerard Hertig, Howell Jackson, Robert Jackson, Anne Joseph O’Connell, Kate Judge, Prasad Krishnamurthy, Margaret Lemos, Christian Leuz, Katerina Linos, Justin McCrary, Emily Meazell, David Min, Saira Mohamed, Saule Omarova, Eric Pan, Katharina Pistor, Ivan Reidel, Susan Rose-Ackerman, Bertrall Ross, Pam Samuelson, Hal Scott, Heidi Schooner, Jodi Short, Fred Smith, Holger Spamann, Eric Talley, Ken Taymor, Pierre Verdier, Kathryn Watts, Chris Whytock, Yesha Yadav, David Zaring, and participants at the Wharton International Finance Conference 2011, the AALS 2012 Meeting, the Texas Law International Finance Symposium 2012, the 2012 Comparative Law and Economics Forum, and the 2012 Conference on Empirical Legal Studies, as well as participants in faculty workshops at UC Irvine and UC Berkeley Law Schools. Rebecca Kwan, Megan Niedermeyer, and Lisa Poplawski provided excellent research assistance. 
agencies. In these councils, supermajority requirements and veto rights designate politicians as the ultimate decision makers.

The Article shows how this paradigm shift resulted from the interplay of factors unique to the 2007-08 crisis and long-run trends. The collapse of institutions in diverse areas of financial activity, including investment banks, insurance companies, and thrifts, created a sense that independent regulators as a class had failed. Concerns about regulatory capture, combined with disillusionment with the markets' potential to self-correct, further undermined confidence in past paradigms. Developments in financial markets attracted great interest from ordinary Americans, who over the last two decades have increasingly relied on the financial system for their pension savings, housing credit, and other investments. Politicians could not remain as distant from financial regulation as in the past.

From a normative standpoint, politicians' greater involvement in financial regulation is in line with calls for enhanced presidential control over independent agencies. Scholars have argued that the President's stamp of approval will increase accountability and boost the legitimacy of hard choices, such as bank bailouts. However, this Article warns that greater political involvement might endanger financial stability. Electoral strategizing can influence politicians' bailout choices, as incumbents might be particularly sensitive to upheavals as elections approach. Politicians are also under pressure from groups at ideological extremes, which often express a deep distrust of the financial system. In this climate, financial institutions are likely to lobby politicians more intensely. Thus, the risk of a financial catastrophe may now hinge upon considerations that have little to do with the health of the financial system.

Introduction

I. The Independent Agency Paradigm in Financial Regulation 336

A. Independent Agencies: The Paradigmatic Regulatory Structure in Finance.

B. Justifications for Independent Agencies' Foundational Role in Financial Regulation

II. The Financial Crisis Challenges the Independent Agency Model....... 343

A. Criticisms of Regulatory Failures Target Multiple Agencies at Once

B. Disillusionment with Markets' Self-Correcting Potential. 346

C. Concerns About Regulatory Capture 348

D. Voter Interest in Financial Regulation 350

E. Independent Agencies Welcomed Politicians' Actions During the Crisis

III. Data and Index Formulation 


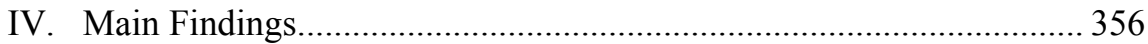

A. Overall Increase in Political Influence over Banking

Supervision 356

B. New Areas of Political Influence: Resolution Authority and

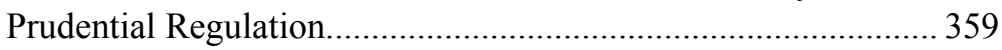

C. New Types of Powers ................................................................. 361

D. Consolidation, Fragmentation, and Reorganization of Regulatory Agencies

V. A New Institutional Design for Banking Supervision in the United States and Abroad. 368

A. The U.S. Financial Stability Oversight Council...............................369

B. The U.S. Orderly Liquidation Authority ........................................370

1. Scope of Orderly Liquidation Authority ...................................370

2. Triggering Orderly Liquidation ............................................... 371

3. Procedure for Initiating Orderly Liquidation ........................... 372

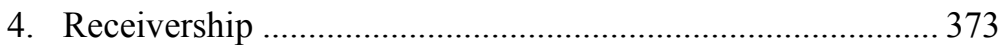

5. Funding for the Intervention ................................................... 374

C. Reformers Abroad Provide Politicians with Wide Discretion in the Context of Common Deliberation and Codecision

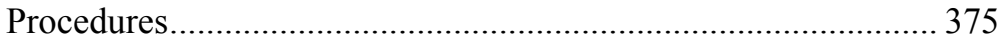

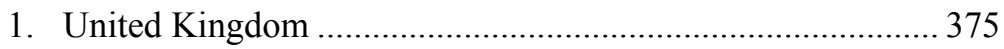

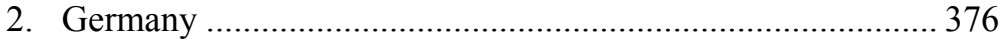

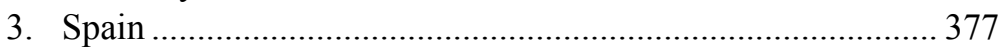

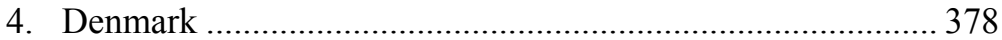

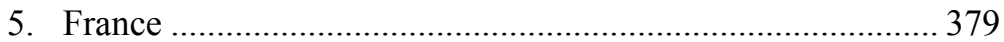

VI. Politicians in Banking Supervision: Benefits and Risks...................... 380

A. Politicians Bring Greater Accountability, Legitimacy, and Effectiveness in Financial Regulation.........................................380

1. Accountability and Legitimacy ...............................................380

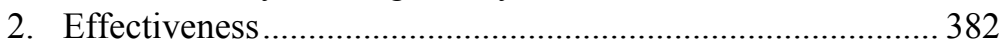

B. Politicians May Rely on Considerations Unconnected to the Merits of a Bailout Choice......................................................... 382

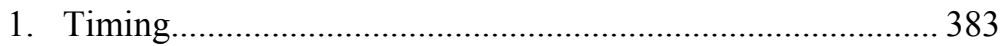

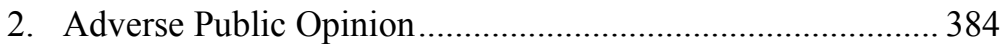

3. Opportunities for Side Bargains.................................................385

C. The Long-Term Horizon of Bailout Choices …………………..... 386

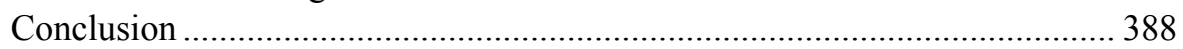

Appendix I: Individual Country Index Scores ………................................. 390

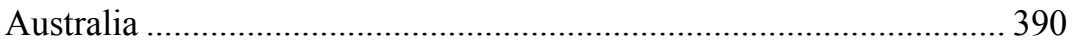

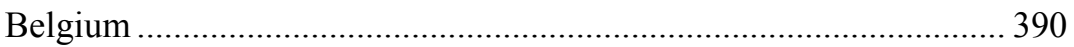

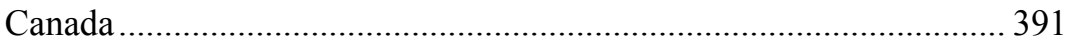

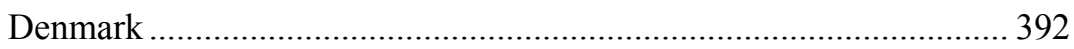

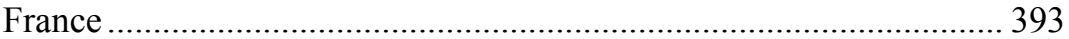




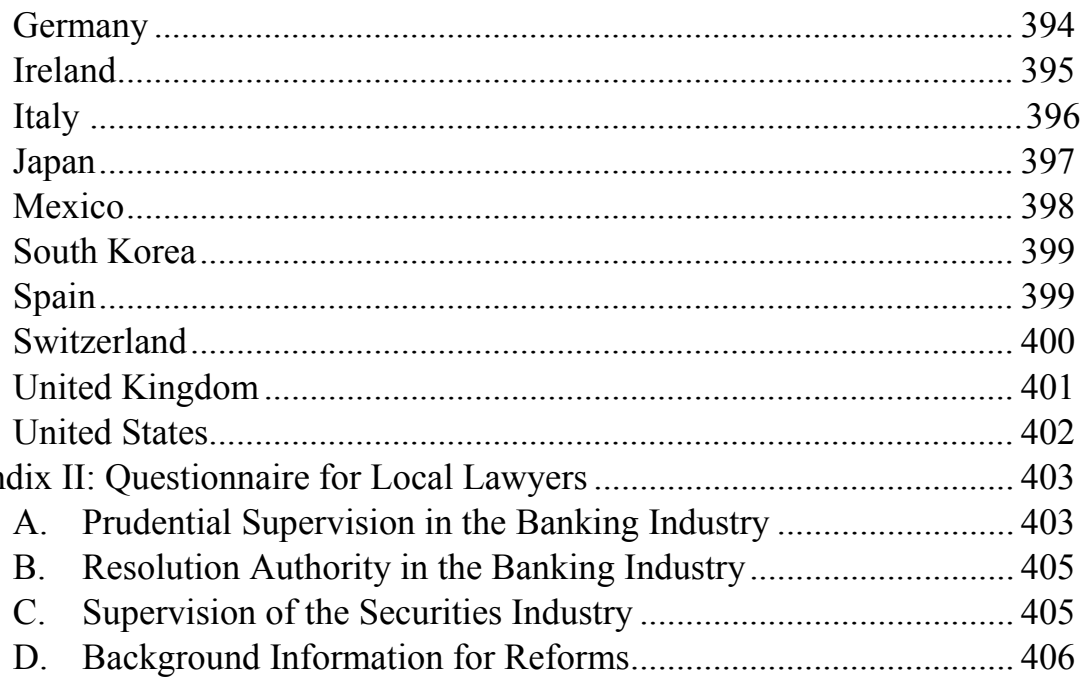

\section{INTRODUCTION}

The dominant paradigm in the U.S. financial regulatory apparatus has long centered on independent agencies like the Federal Reserve, the Federal Deposit Insurance Corporation (FDIC), and the Securities and Exchange Commission (SEC). ${ }^{1}$ Compared to politically controlled appointees, some theorists argue, independent bureaucrats offer invaluable advantages. ${ }^{2}$ Free from the constraints of electoral battles, independent agencies can devote their energy toward building up expertise and developing the skills and knowledge necessary to delve into the intricate details of highly technical regulatory areas. ${ }^{3}$

1. See Lisa Schultz Bressman \& Robert B. Thompson, The Future of Agency Independence, 63 VAND. L. ReV. 599, 602 (2010); Richard H. Pildes, Separation of Powers, Independent Agencies, and Financial Regulation: The Case of the Sarbanes-Oxley Act, 5 N.Y.U. J.L. \& BuS. 485, 489 (2009). The Federal Reserve System was created in 1913 by the Federal Reserve Act, ch. 6, 38 Stat. 251 (1913). The FDIC and the SEC date from the New Deal era. The FDIC was established in 1933 by the Glass-Steagall Act, also known as the Banking Act of 1933, ch. 89, 48 Stat. 162. The SEC was established in 1934 by the Securities Exchange Act, Pub. L. No. 73-291 48 Stat. 881 (1934).

2. See generally Mark Tushnet, Administrative Law in the 1930s: The Supreme Court's Accommodation of Progressive Legal Theory, 60 DUKE L.J. 1565 (2011) (explaining how beliefs about independent agencies' superior abilities as compared to the legislature or the judiciary undergirded the views of thinkers such as Felix Frankfurter, James Landis, Isaiah Leo Sharfman, and others, who were instrumental in the establishment of the administrative state); Geoffrey P. Miller, The Debate over Independent Agencies in Light of Empirical Evidence, 1988 DUKE L.J. 215, 218 (calling for an empirical approach to assessing independent agencies' contributions and costs); Joseph P. Witherspoon, Civil Rights Policy in the Federal System: Proposals for a Better Use of Administrative Process, 74 YALE L.J. 1171, 1210 (1965) (emphasizing independent agencies' higher abilities and unbiased judgment).

3. See Elizabeth Magill \& Adrian Vermeule, Allocating Power Within Agencies, 120 YALE L.J. 1032, 1035 (2011) (suggesting that administrative law relies on expertise to allocate authority among various professionals - lawyers, scientists, and others - that participate in each agency); Bressman \& Thompson, supra note 1, at 612; Jonathan S. Masur \& Jonathan Remy Nash, The Institutional Dynamics of Transition Relief, 85 N.Y.U. L. REV. 391, 449 (2010) (recognizing expertise 
Moreover, while politicians in pursuit of reelection are sensitive to their voters' urgent demands, independent agencies can prioritize long-term policy goals over immediate gains and ensure regulatory stability. ${ }^{4}$ Widely acclaimed as experts with long-term horizons, independent agencies have remained the bedrock of the institutional framework governing U.S. markets, even as successive waves of reforms have changed many other substantive aspects of U.S. financial regulation. ${ }^{5}$

Since the early 1990s, most Western democracies have followed the United States' lead and strengthened the independence of their financial regulators. ${ }^{6}$ Influential international organizations, such as the Basel Committee $^{7}$ and the International Monetary Fund (IMF), ${ }^{8}$ encouraged countries to bolster the independence of their financial supervisors. Leading academic commentators support agency independence in the financial regulatory sphere and track countries' progress toward more independent institutional

as the defining institutional feature of independent agencies); William W. Buzbee, Preemption Hard Look Review, Regulatory Interaction, and the Quest for Stewardship and Intergenerational Equity, 77 GEO. WASH. L. REV. 1521, 1543 (2009) (describing how regulators' first-mover advantages assist them in developing expertise). Viewing independent agencies as the primary experts in a technical field has shaped some of the most central judicial holdings in administrative law, such as the deference doctrine articulated by the Supreme Court in Chevron U.S.A. Inc. v. Natural Resources Defense Council, Inc., 467 U.S. 837, 865 (1984). For additional discussion of expertise as justification for agency independence, see infra Part I.B.

4. See Alan M. Jacobs, GOVERNING FOR THE LONG TERM: DEMOCRACY AND THE POLITICS OF INVESTMENT 28-30 (2011); Anne Joseph O'Connell, Agency Rulemaking and Political Transitions, 105 Nw. U. L. REV. 471, 526 (2011) (viewing stability as a corollary to expertise); Rachel E. Barkow, Insulating Agencies: Avoiding Capture Through Institutional Design, 89 TEX. L. REV. 15, 24 (2010) (noting the stability rationale in the creation of the Federal Reserve and the Federal Trade Commission). For a more extensive discussion of policy stability and delegation to independent agencies, see infra Part I.B.

5. See Martin Shapiro, A Comparison of US and European Independent Agencies, in Comparative AdMinistrative LaW 293 (Susan Rose-Ackerman \& Peter L. Lindseth eds., 2010). Part I.B elaborates on these themes.

6. See Fabrizio Gilardi, The Formal Independence of Regulators: A Comparison of 17 Countries and 7 Sectors, 11 SwISS POL. SCI. REV. 139, 139-40 (2005) ("Over the past fifteen years, independent regulatory agencies (IRAs) have become a common institutional form in regulatory policies ... . They have been established in all West European countries.").

7. See BASEl COMM. ON BANKING SuPERVISION, CORE Principles fOR EFFeCtive BANKING SUPERVISION 2 (2006), available at $\mathrm{http}: / / \mathrm{www} \cdot \mathrm{bis}$. org/publ/bcbs129.pdf (listing as one of the core principles for effective banking that "[e]ach such authority should possess operational independence").

8. See Marc Quintyn et al., The Fear of Freedom: Politicians and the Independence and Accountability of Financial Sector Supervisors 37 (Int'l Monetary Fund, Working Paper No. 07/05, 2007), available at $\mathrm{http} / / / \mathrm{www} .0 e c d . o r g /$ dataoecd/5/57/38151620.pdf. 
mechanisms. ${ }^{9}$ In scholarly circles and in the field of policy action alike, agency independence has long been the hallmark of financial regulation. ${ }^{10}$

This Article argues that the agency independence paradigm is under attack. The financial crisis of 2007-08 prompted policy makers worldwide to establish new regulatory mechanisms designed to monitor financial institutions more thoroughly and to facilitate intervention in case of emergency. That new regulations followed a major crisis is hardly surprising; what is surprising are the government bodies chosen to wield these new powers. Instead of independent banking regulators, postcrisis reformers assigned the new powers to politically controlled officials, typically high-ranking executive officers such as treasury secretaries and finance ministers. ${ }^{11}$ These cabinet appointees sit very close to the chief executive, president, or prime minister, who can typically remove them at will. As a result, there is now a direct link between the top elected officer and banking supervision. The Article details the characteristics of politicians' new role, proposes an explanation for the abrupt paradigm shift, and formulates predictions about politicians' performance by applying insights from a long tradition of studies on democracy to financial regulation.

This Article documents that the move away from regulatory independence and toward greater political involvement in postcrisis banking regulation constitutes a global paradigm shift. ${ }^{12}$ To show these reforms' global appeal, the Article covers fifteen key jurisdictions for international financial markets: the United States, Canada, Mexico, the United Kingdom, France, Germany, Belgium, Ireland, Spain, Italy, Denmark, Switzerland, Japan, Australia, and South Korea. The Article presents the results of primary legal research on each jurisdiction's laws, conducted by locally trained lawyers. Each lawyer responded to the same questionnaire of about forty questions on bank supervision. These lawyers provided a snapshot of the regulatory framework as it stood in two separate points in time: first, on April 30, 2007, as the crisis was beginning, and second, on December 1, 2010, by when most reforms were complete. ${ }^{13}$ To help present these responses, the Article summarizes results into

9. See, e.g., Alex Cukierman et al., Measuring the Independence of Central Banks and Its Effect on Policy Outcomes, 6 WORLD BANK ECON. REV. 353 (1992); Alberto Alesina, Macroeconomics and Politics, in 3 NBER MACROECONOMICS ANNUAL 13 (Stanley Fischer ed., 1988).

10. See Steven Seelig \& Alicia Novoa, Governance Practices at Financial Regulatory and Supervisory Agencies 6-7 (Int'l Monetary Fund, Working Paper No. 09/135, 2008), available at http://www.oecd.org/site/iops/documents/43413373.pdf (presenting a 2007 survey of agency independence in 103 countries, and demonstrating that 75 percent of standalone agencies possessed operational independence).

11. See infra Part IV.A.

12. For a discussion of changes at the interstate level, see Eric Helleiner \& Stefano Pagliari, Crisis and the Reform of International Financial Regulation, in GLOBAL FINANCE IN CRISIS: THE POLITICS OF INTERNATIONAL REGULATORY CHANGE 1, 4-8 (Eric Helleiner et al. eds., 2010).

13. The questionnaire is reproduced in Appendix II. 
an index of fifteen important powers. ${ }^{14}$ The results of this research show a marked increase in politicians' influence over banking regulation and supervision in most jurisdictions that introduced reforms between 2007 and 2010. Leading the trend toward greater political influence are the jurisdictions with the most important financial markets: the United States, the United Kingdom, France, and Germany all introduced reforms strengthening politicians' role. ${ }^{15}$

The degree of politicians' newly found influence over banking supervision is evident in three distinct institutional features of their new powers. First, politicians now have authority not only over financial emergencies, but also over some regular issues arising during times of smooth business operation. Politicians cast the decisive vote on the decision to sustain or terminate an ailing institution, including whether to declare it bankrupt, liquidate it, take it over, or sell it. In addition to emergency situations, politicians now also have a say over some key aspects of a financial institution's regular operation, such as licensing its establishment, requiring stricter prudential supervision, or approving its managers' appointment. ${ }^{16}$ Second, politicians' new powers represent direct grants of authority. ${ }^{17}$ Rather than relying on appointment powers to select bureaucrats with whom they share a regulatory philosophy, politicians can now explicitly undertake or authorize specific actions against individual financial institutions. ${ }^{18}$ A third feature of postcrisis reforms is politicians' newly acquired status as the leaders of administrative coordination mechanisms that encompass preexisting agencies. To address the obvious need for exchange of information and coordination of regulatory action in light of systemic threats, reformers put in place institutional arrangements that bring all financial regulators around the same table under the leadership of politicians. ${ }^{19}$

These institutional arrangements, this Article argues, define a new balance of power between agencies and politicians. Agencies, as the primary experts in financial markets, collect information, assess alternatives, and formulate proposals for action. Ultimately, however, the decision over whether to intervene in the market belongs to politicians. This nuanced relationship between agencies and politicians emerged with striking similarity in reforms that occurred in multiple countries within months of one another.

This move away from the deep-rooted paradigm of independent bureaucrats looks even more unusual compared to regulatory reforms after past

14. See infra Part IV.A.

15. In Japan, the only leading jurisdiction that did not introduce any reforms after 2008, politicians already wielded significant influence over financial regulation. See infra Part IV A.

16. See infra Part IV.B.

17. See infra Part IV.C.

18. See infra Part IV.C.

19. See infra Part V. 
financial disasters, in which independent bureaucrats typically increased their powers rather than losing ground. In 2002, the Sarbanes-Oxley Act responded to the Enron and WorldCom scandals by expanding the SEC's powers in corporate governance. $^{20}$ In 1989, the savings and loan crisis led to the establishment of a new independent agency, the Federal Housing Finance Board. $^{21}$ Similarly, the 1982 Mexican debt crisis prompted the establishment of capital adequacy requirements for banks under the supervision of the Federal Reserve. $^{22}$ The familiar pattern of increasing independent regulators' powers following a crisis is common outside the United States as well; for example, many jurisdictions affected by the Asian crisis in the 1990s reinforced the independence of their regulators. ${ }^{23}$ In a sharp departure from earlier regulatory prototypes, elected politicians, rather than independent agencies, wield the most important new powers created in the reforms that followed the 2007-08 crisis.

To explain how this abrupt paradigm shift came about, this Article points to a powerful dynamic between factors unique to the 2007-08 crisis and longrunning trends in the financial markets. ${ }^{24}$ While past financial upheavals typically centered on one area of financial activity, the 2007-08 crisis spanned multiple such areas and, consequently, involved multiple financial regulatorsthe SEC, ${ }^{25}$ the Federal Reserve, ${ }^{26}$ and the now-eliminated Office of Thrift Supervision (OTS), ${ }^{27}$ among others. Such generalized failure suggested that, beyond any problems with how individual regulators performed their separate missions, the regulatory paradigm itself was faltering. At the same time, disillusionment with markets' self-correcting potential engulfed even wellknown advocates of free-market ideals and reinforced calls for stricter

20. See Roberta Romano, The Sarbanes-Oxley Act and the Making of Quack Corporate Governance, 114 YALE L.J. 1521, 1523 (2005).

21. See James R. Barth \& R. Dan Brumbaugh, Jr., The Rough Road from FIRREA to Deposit Insurance Reform, 2 STAN. L. \& POL'Y REV. 58, 60 (1990).

22. See Thomas Oatley \& Robert Nabors, Redistributive Cooperation: Market Failure, Wealth Transfers, and the Basel Accord, 52 INT'L ORG. 35, 43-45 (1998).

23. See Quintyn et al., supra note 8, at 21.

24. See infra Part II.

25. See Stavros Gadinis, The SEC and the Financial Industry: Evidence from Enforcement Against Broker-Dealers, 67 BUS. L. 679, 680 (summarizing reactions against the SEC in the wake of the 2007-08 crisis); U.S. SEC. \& EXCH. COMM'N, OFFICE OF INSPECTOR GEN., SEC's OVERSIGHT OF BEAR STEARNS AND RELATED ENTITIES: BROKER-DEALER RISK ASSESSMENT PROGRAM 2-3 (2008) (finding that the SEC's staff does not receive the necessary documentation from regulated entities to properly supervise them). Part II.A below details criticisms against the SEC.

26. See Brooksley Born, Deregulation: A Major Cause of the Financial Crisis, 5 HARV. L. \& POL'Y REV. 231, 241 (2011). See infra Part II.A for a greater discussion of criticisms against the Federal Reserve.

27. See, e.g., Dain C. Donelson \& David Zaring, Requiem for a Regulator: The Office of Thrift Supervision's Performance During the Financial Crisis, 89 N.C. L. REV. 1777, 1779 (2011) (detailing criticisms from various quarters against OTS for its supervision of thrifts like Washington Mutual and insurance companies like AIG). 
regulation. ${ }^{28}$ As government bailouts unfolded, concerns about regulatory capture and close relationships between the financial industry and government officials dominated the popular press. ${ }^{29}$ The financial turmoil attracted heightened public interest, as most Americans felt the impact of the crisis in their personal finances and followed closely the dramatic developments in the markets. ${ }^{30}$ This unprecedented public attention turned financial regulation into an area of primary concern for politicians in need of voter support. Throughout the crisis, politicians worked closely with regulators, who often welcomed the involvement of treasuries and financial ministries in their efforts to constrain the crisis. 31

This Article closes by analyzing the relative strengths and weaknesses of politicians' new role in financial regulation from a normative standpoint. A prominent school of thought in administrative law has long advocated for a greater role for the President over independent agencies, so as to improve agency responsiveness to voter concerns and strengthen the legitimacy of agency actions. ${ }^{32}$ According to this view, requiring the President's stamp of approval on bailout choices ensures that banking supervision aligns with the preferences of the electorate. ${ }^{33}$ Yet thrusting politics into the hitherto insulated world of financial regulation is not without its drawbacks. ${ }^{34}$ To start, the timing of a crisis in relation to the electoral cycle might bias politicians' responses, since incumbents would not want an economic catastrophe to mar their reelection campaigns. ${ }^{35}$ A bailout dictated by electoral timing has little to do with an objective assessment of the financial circumstances. On the other hand, political movements as diametrically opposed as the Tea Party ${ }^{36}$ and Occupy

28. See, e.g., The Financial Crisis and the Role of Regulators: Hearing Before the H. Comm. on Oversight and Gov't Reform, 110th Cong. 17 (Oct. 23, 2008) (statement of Alan Greenspan, Former Chairman, Fed. Reserve Bd.) ("Those of us who have looked to the self-interest of lending institutions to protect shareholder's [sic] equity (myself especially) are in a state of shocked disbelief."). Part II.B below provides additional examples.

29. See, e.g., Michael Lewis \& David Einhorn, Op-Ed., The End of the Financial World as We Know It, N.Y. TIMES, Jan. 4, 2009, at WK9 (castigating SEC officials for bias in favor of big investment banks because of the revolving door between the SEC and the financial industry). Part II.C below expands on concerns for regulatory capture during the financial crisis.

30. See infra Part II.D (describing a CBS poll showing increased public interest in developments in the financial markets).

31. For an example from the United States, see Bressman \& Thompson, supra note 1, at 642. For examples from other jurisdictions, see infra Part II.E.

32. See James F. Blumstein, Regulatory Review by the Executive Office of the President: An Overview and Policy Analysis of Current Issues, 51 DuKE L.J. 851, 885 (2001); Elena Kagan, Presidential Administration, 114 HARV. L. REV. 2245, 2384 (2001); Laurence Lessig \& Cass R. Sunstein, The President and the Administration, 94 COLUM. L. REV. 1, 103 (1994).

33. Some have argued that when agencies fail to do what elected officials would have done, we are faced with a "regulatory 'failure." See Lloyd N. Cutler \& David R. Johnson, Regulation and the Political Process, 84 YALE L.J. 1395, 1399 (1975).

34. See infra Part II.C.

35. See Anne Joseph O'Connell, Political Cycles of Rulemaking: An Empirical Portrait of the Modern Administrative State, 94 VA. L. REV. 889, 892-94 (2008).

36. See Gerald F. Seib, No Seat for Wall Street at Tea Party, WALL ST. J., Jan. 12, 2010, at A2. 
Wall Street ${ }^{37}$ agree on little else apart from condemning bailouts, adding to the traditional distrust of the American public toward banking. As the survival of the financial system might be caught in political crossfire, financial institutions have clear incentives to step up their efforts to influence politicians, such as by increasing campaign contributions or providing financing to industries in line with the President's agenda.

This Article proceeds as follows. Part I introduces the independent agency paradigm and explains how its traditional justifications, such as technical expertise and policy stability, found a strong application in financial regulation. Part II identifies factors that undermined confidence in the conventional paradigm of agency independence during the 2007-08 crisis and led policy makers down a different path. The Article then moves to explore postcrisis reforms. Part III describes the data collection process and the formulation of the index used here. Part IV presents the main findings of the Article and documents the shift away from agency independence toward greater political control. Part V outlines the new balance between politicians and agencies in banking supervision, discusses in detail the institutional arrangements between politicians and independent agencies under the Dodd-Frank Act in the United States, ${ }^{38}$ and shows how similar institutional formations also arise in other jurisdictions. Part VI analyzes the advantages and risks of handing a crucial role in banking supervision to political leaders.

I.

\section{THE INDEPENDENT AGENCY PARADIGM IN FInANCIAL REgULATION}

Independent agencies have been a standard feature of the modern regulatory state for a century, ${ }^{39}$ even though the degree of agency independence, and the institutional features that guarantee it, vary across agencies and across jurisdictions. Thus, this Article begins by defining an independent agency in negative terms: an independent agency is a government body "neither directly elected by the people, nor directly managed by elected officials." $" 40$ This government body exercises regulatory policy-making authority in a specialized issue area, typically following a delegation of specific powers by the legislature. These institutional arrangements were designed to

37. See Mark Egal \& Michelle Nichols, Who's Behind the Wall Street Protests?, ReUTERS (Oct. 13, 2011), http://www reuters.com/article/2011/10/14/us-wallstreet-protests-origins-idUSTRE79 C1YN20111014; Andrew Ross Sorkin, On Wall St., a Protest Matures, N.Y. TIMES, Oct. 4, 2011, at B1.

38. Dodd-Frank Wall Street Reform and Consumer Protection Act (the Dodd-Frank Act), Pub. L. No. 111-203, 124 Stat. 1376 (2010) (codified in various sections of the U.S. Code).

39. The Interstate Commerce Commission (ICC) was the first independent regulatory agency, established by the Interstate Commerce Act of 1887, ch. 104, 24 Stat. 379, and abolished in 1996 by the ICC Termination Act of 1995, Pub. L. No. 104-88, 109 Stat. 803 (codified as amended in scattered sections of 49 U.S.C.).

40. Mark Thatcher \& Alec Stone Sweet, Theory and Practice of Delegation to NonMajoritarian Institutions, 25 WEST EUR. POL. 1, 2 (2002) (emphasis added). 
reduce the influence of the executive on the independent bureaucracies. These bureaucracies, it was hoped, would be less vulnerable to the influence of interest groups than politicians, who seek these groups' support in order to secure reelection. $^{41}$

This Part begins by demonstrating the widespread reach of the independent agency paradigm. It then discusses two key features that scholars have associated with independent bureaucracies, namely high technical expertise and long-term policy orientation. Having thus grounded independent agencies on administrative law scholarship, this Part draws from the conclusions of that literature to explain why independent bureaucracies represent a good match for financial regulation.

\section{A. Independent Agencies: The Paradigmatic Regulatory Structure in Finance}

In the United States, independent agencies were a hallmark of the New Deal effort to build an efficient bureaucracy. As early as $1935,{ }^{42}$ the Supreme Court embraced agency independence and situated it firmly within America's separation-of-powers tradition. The Court recognized Congress's authority to establish administrative agencies and limit the President's power to remove the members of these agencies' boards, except for cause. This limitation on the President's removal power is now the defining feature of agency independence in the United States. Most U.S. independent agencies are governed by a bipartisan commission, where members from the President's party constitute a bare majority. $^{43}$

Outside the United States, the criteria for determining agency independence are more varied. European countries have emphasized the position of these agencies outside the traditional executive-body hierarchy. ${ }^{44}$ At a minimum, an agency is formally independent when it can exercise its powers without having to obtain the consent of elected government officials like ministers or prime ministers. ${ }^{45}$ Yet, elected politicians may be able to influence an agency's decision-making process in various ways. For example, the legislature may grant only limited powers to the agency, requiring it to seek politicians' support in order to further its policy goals. Or, the legislature may curtail the agency's budget. For all these reasons, academic studies of agency independence have moved away from relying on a single criterion of

41. See Barkow, supra note 4, at 17 ("The insulated agency, its designers hope, will better resist short-term partisan pressures and instead place more emphasis on empirical facts that will serve the public interest in the long term.").

42. Humphrey's Ex'r v. United States, 295 U.S. 602, 629 (1935).

43. See Barkow, supra note 4, at 40-41.

44. Shapiro, supra note 5, at 305.

45. See Aalt Willem Heringa \& Luc F.M. Verhey, Independent Agencies and Political Control, in Agencies IN EuROPEAN AND COMPARAtive Perspective 156 (Luc Verhey \& Tom Zwatt eds., 2003). 
independence in favor of a more comprehensive analysis of the agency's institutional environment. ${ }^{46}$

Financial regulation has traditionally constituted one of independent agencies' primary domains. The Federal Reserve, the FDIC, the SEC, and the Community Futures Trading Commission (CFTC) were established with strong guarantees of independence from the executive. These agencies dominate the nation's financial markets, with a regulatory portfolio that covers some of the most important areas of the financial system: bank chartering, monitoring of equity offerings and stock exchange trading, supervision of investment banks, regulation of derivatives, securitization and mutual funds, and numerous other topics. Although these agencies vary with regard to the institutional arrangements for insulation from politics, they all enjoy a significant degree of independence. $^{47}$

Whereas the United States was an early adopter of agency independence in financial regulation, most other developed and developing countries moved in the same direction throughout the 1980s and 1990s. European countries, partly under the pressure of E.U. regulation, introduced agency independence en masse in their regulatory reforms beginning in the mid-1980s. ${ }^{48}$ In Japan, the central government maintained the legal power to intervene in the supervision of financial markets, but has rarely exercised that power, if ever. ${ }^{49}$ Countries that experienced significant financial crises in the 1990s-like Indonesia, Mexico, and Korea-responded by strengthening the independence of their regulatory bodies. ${ }^{50}$ By 2008, independence for financial supervisory agencies was widespread around the world. ${ }^{51}$

Apart from domestic legislators, international organizations active in financial-sector reform became strong advocates for agency independence. The Basel Committee declared regulator independence as one of its core principles of banking supervision. ${ }^{52}$ The IMF actively advocated for the independence of financial-sector supervisors, arguing that the intervention of political forces in

46. See, e.g., Gilardi, supra note 6, at 140.

47. For example, Congress approves the SEC's annual budget, but has limited auditing and budgetary powers over the Federal Reserve. See Elizabeth F. Brown, The New Laws and Regulations for Financial Conglomerates: Will They Better Manage the Risks Than the Previous Ones?, 60 AM. U. L. REV. 1339, 1375-76 (2011).

48. See Fabrizio Gilardi, The Institutional Foundations of Regulatory Capitalism: The Diffusion of Independent Regulatory Agencies in Western Europe, 598 ANNALS AM. ACAD. POL. \& SOC. SCI. 84, 85, 89-90 (2005).

49. See Stavros Gadinis \& Howell E. Jackson, Markets as Regulators: A Survey, 80 S. CAL. L. REV. 1239, 1306-07 \& n.203 (2007).

50. See Quintyn et al., supra note 8, at 21.

51. See Seelig \& Novoa, supra note 10 (presenting a survey of 103 countries demonstrating that 75 percent of the sample space had ensured operational independence to their financial regulators).

52. See BASEl COMM. ON BANKING SUPERVISION, supra note 7, at 2 (including within the first Core Principle the provision that "[e]ach such authority should possess operational independence"). 
financial crises only made matters worse. ${ }^{53}$ Throughout the early $2000 \mathrm{~s}$, the IMF continued to monitor whether financial-regulation reforms strengthened agency independence. IMF-sponsored studies noted the continuing growth of agency independence around the world, but complained that reforms had not gone far enough. ${ }^{54}$

As these studies note, there is great variation in the institutional structure of agency independence in jurisdictions around the world. Countries vary in the degree of legal immunity they award to staff members, in the degree of their regulators' reliance on state budgets or on independent sources of fundingsuch as industry fees - and in the criteria for appointing and removing top agency officials. ${ }^{55}$ Ultimately, some countries maintain a tighter grip than others in agency policy making and enforcement. Yet these studies confirm that countries around the world viewed independence as an indicator of the quality of financial regulation. Thus, there is little doubt that the rhetoric of independence remained powerful throughout the period that preceded the 2007-08 financial crisis.

\section{B. Justifications for Independent Agencies' Foundational Role in Financial Regulation}

Theorists have offered two major justifications for the independent agency model. A first group of scholars portray independent bureaucrats as dispassionate experts: rational actors who reach decisions on the basis of scientific evidence rather than partisan preferences. A second set of theories points out that, because independent bureaucrats do not have to win elections every few years, they can prioritize long-term goals and avoid the trap of policies with immediate benefits but disproportionate future costs. This Section looks at these two arguments for independence in turn and applies them in the context of banking regulation.

Proponents of agency independence believe in the need to build an administration staffed by expert career bureaucrats, rather than opportunistic political appointees. Civil servants with deep knowledge of their policy fields 56 are best suited to find scientific solutions to issues of regulatory policy. ${ }^{57}$ Issues

53. See generally Marc Quintyn \& Michael W. Taylor, Regulatory and Supervisory Independence and Financial Stability (Int'1 Monetary Fund, Working Paper No. 02/46, 2002) (making the case for the independence of financial regulators).

54. See, e.g., Donato Masciandaro et al., Financial Supervisory Independence and Accountability -Exploring the Determinants, (Int'1 Monetary Fund, Working Paper No. 08/147, 2008); Quintyn et al., supra note 8, at 35.

55. See Quintyn et al., supra note 8, at 23.

56. See Bressman \& Thompson, supra note 1, at 612 .

57. JAMES M. LANDIS, ThE ADMINISTRATIVE PROCESS 23-24, 113-14 (Greenwood Press 1974) (1966). For a discussion of Landis's views, see generally Charles H. Koch, Jr., James Landis: The Administrative Process, 48 ADMIN. L. REV. 419 (1996) (discussing the multifaceted contribution of Landis's work in administrative-law scholarship). 
of regulatory policy often involve questions of a highly technical nature that generalist politicians may find impenetrable. Indeed, some scholars argue that, in certain issue areas, the level of technical knowledge required can be so high that politicians will have trouble supervising agency policies and auditing agency practices. ${ }^{58}$

Perhaps few areas fit the mold of a highly technical field as well as financial regulation. Financial regulators need officials who understand how financial markets work and who are familiar with the business model, transaction types, compliance mechanisms, and record-keeping procedures of leading financial institutions. ${ }^{59}$ Modern financial transaction structures, which typically combine, slice, or recompose cash flows from diverse sources in order to balance various risks, are tremendously complicated for nonexperts. Securitizations, which paved the way for the extension of subprime mortgages, exemplify the need for well-informed regulators. While the issue of subprime mortgages involves mostly banking and consumer law principles, securitization design is significantly more complex. It involves bankruptcy law and corporate law, which ensure the independence and bankruptcy remoteness of the entity acquiring the receivables; derivatives law, which addresses the need for ongoing liquidity to smooth out payments to noteholders; and securities law, which governs the creation and offering of the notes. ${ }^{60}$ How these transaction structures operate should be clear to the government officials responsible for maneuvering through crises beforehand because they will typically have little time to educate themselves once a crisis strikes. Moreover, officials should be able to establish direct channels of communication with managers of financial institutions who can help them broker innovative solutions, like a merger with another institution, when a crisis hits. ${ }^{61}$

A second strand in the literature looks at independent agencies not only as repositories of expertise, but also as guarantors of policy stability and uniformity. ${ }^{62}$ Scholars advocating this view are concerned that, when elected politicians are given free rein, they often choose policies that confer short-term advantages to some key voter groups but lead to long-term harms to society at large. For example, if politicians were in charge of setting interest rates, they would be likely to oversupply credit to the economy in order to please voters, disregarding any inflation effects. Central bank independence is lauded as a way to prioritize low inflation targets and resist pressures to stimulate the

58. See Jeffrey S. Banks \& Barry R. Weingast, The Political Control of Bureaucracies Under Asymmetric Information, 36 AM. J. POL. SCI. 509, 511 (1992).

59. For a discussion of the SEC's oversight authority over financial institutions' compliance obligations, see Gadinis, supra note 25, at 715-22.

60. For an overview of securitization structures, see Steven L. Schwarcz, The Alchemy of Asset Securitization, 1 STAN. J.L. Bus. \& FIN. 133 (1994).

61. See Bressman \& Thompson, supra note 1, at 614.

62. See Jacobs, supra note 4, at 28-30. 
economy in the short term, in order to achieve long-term growth. ${ }^{63}$ This literature documents that as countries strengthen the independence of their central banks they experience lower inflation rates and, consequently, higher levels of long-term growth and investment. ${ }^{64}$

Scholars of institutional design apply this insight to areas beyond monetary policy. Stability in regulatory outcomes is valuable to private investors, who often tailor their business models to particular regulatory frameworks. Private investors may fear that the state will manipulate regulatory policy in the future to appropriate their profits. ${ }^{65}$ For example, a new government may remove a regulatory license granted by its predecessors, lower regulatory standards and allow low-quality competitors to enter the market, or retract efforts to liberalize markets. To alleviate such fears, governments must offer to private investors some credible commitment that, even after they leave power, the state apparatus will continue to support key regulatory-policy goals. This reassurance comes in the form of independent agencies, which remain attached to their missions even in the face of a change in government. ${ }^{66}$ Changes in government policies are particularly important to financial institutions, since laws and regulations determine crucial aspects of financial activity, such as the creation of financial products, the rights of investors acquiring them, and the licensing and conduct of firms offering these products to the public. ${ }^{67}$ If government policies relating to these aspects remain stable over time, financial institutions can reduce adjustment costs and build more enduring business models.

An independent agency's commitment to stable policies extends not only over time, but also across firms. If the government treated financial institutions differentially depending on their political alliances, some firms would receive unfair regulatory advantages. Yet independent regulators, who have no direct political gains to earn or role to secure, are more likely to adopt a common approach toward all firms. Regulators' adherence to a common approach irrespective of political benefits and costs motivated some noteworthy Federal

63. See, e.g., Kenneth Rogoff, The Optimal Degree of Commitment to an Intermediate Monetary Target, 100 Q.J. ECON. 1169, 1169 (1985).

64. See Alex Cukierman, Central Bank Independence and Monetary Policymaking Institutions-Past, Present and Future, 24 EUR. J. POL. ECON. 722, 728 (2008). For a discussion of the interaction between the legislative and the executive branches in connection with central-bank independence, see generally William Bernhard, A Political Explanation of Variations in Central Bank Independence, 92 AM. POL. SCI. REV. 311 (1998) (linking variations in central-bank independence to electoral politics in each jurisdiction).

65. See Douglass C. North \& Barry R. Weingast, Constitutions and Commitment: The Evolution of Institutions Governing Public Choice in Seventeenth-Century England, 49 J. ECON. HIST. 803, 808 (1989).

66. See Witold Jerzy Henisz, Political Institutions and Policy Volatility, 16 ECON. \& POL. 1, 2 (2004).

67. See Stavros Gadinis, The Politics of Competition in International Financial Regulation, 49 HARV. INT’L L.J. 447, 448 (2008). 
Reserve actions during the 2007-08 period. At the heart of the crisis, the Federal Reserve provided extensive financial assistance to foreign financial institutions - mostly European banks - that were central to the stability of the U.S. financial system. ${ }^{6}$ It is unlikely that U.S. politicians would have been willing to offer similar support to institutions when doing so would not result in direct electoral gain and could even prove to be an electoral liability.

Notwithstanding independent agencies' advanced expertise and dedication to policy stability, the financial system has experienced multiple disturbances of varying importance over the years. These financial system failures often triggered criticisms against financial regulators. Some scholars decried agencies' policies as unduly interventionist, ${ }^{69}$ while others worried that special interest groups in the financial industry had managed to capture regulators. ${ }^{70}$ Criticism was not limited to academic circles: on occasion, courts struck down regulators' decisions. $^{71}$

Yet the response to past financial failures involved regulatory reforms that typically strengthened the position of independent financial regulators, rather than weakening it. Although Congress repeatedly amended banking and securities laws prior to 2008 , it continued to focus on empowering independent financial regulators, cementing their positions and expanding their influence. For example, when the Enron and WorldCom scandals raised doubts about the quality of financial reporting among public companies, the Sarbanes-Oxley Act increased the SEC's powers over corporate governance. ${ }^{72}$ Following the savings and loan crisis, Congress established a new independent agency, the Federal Housing Finance Board, to oversee federal home loan banks. ${ }^{73}$ Another expansion of independent regulators' powers over banks came with the establishment of capital adequacy requirements to be monitored by the Federal Reserve. U.S. banks accepted these requirements in return for a government bailout: they received significant support from the government and the IMF when their heavy lending to Latin American countries-mostly Mexicoresulted in extensive defaults in $1982 .{ }^{74}$ Similarly, financial crises outside the United States typically motivated foreign lawmakers to increase the powers of

68. See Bradley Keoun \& Craig Torres, Foreign Banks Tapped Fed's Secret Lifeline Most at Crisis Peak, BloOMBerg (Apr. 1, 2011, 10:53 AM), http://www.bloomberg.com/news/2011-0401/foreign-banks-tapped-fed-s-lifeline-most-as-bernanke-kept-borrowers-secret html.

69. See Romano, supra note 20, at 1523.

70. See Lawrence G. Baxter, Capture Nuances in Financial Regulation, 47 WAKE FOREST L. REV. 537, 550 (2012); M. Todd Henderson \& Frederick Tung, Pay for Regulator Performance, 85 S. CAL. L. REV. 1003, 1050-51 (2012); Saule T. Omarova, Bankers, Bureaucrats, and Guardians: Toward Tripartism in Financial Services Regulation, 37 J. CORP. L. 621, 625-32 (2012). For more extensive discussion of theories of capture, see infra Part II.C.

71. See, e.g., Bus. Roundtable v. SEC, 905 F.2d 406, 410-17 (D.C. Cir. 1990) (striking down Rule 19c-4 as exceeding the SEC's authority).

72. See Romano, supra note 20, at 1523.

73. See Barth \& Brumbaugh, supra note 21, at 60 .

74. See Oatley \& Nabors, supra note 22, at 43-45. 
independent regulators. For example, many Asian nations hit particularly hard by the 1997 Asian crisis responded by boosting regulatory independence. ${ }^{75}$ In short, past legislators interpreted earlier crises as indicative of regulatory gaps, which they sought to remedy by providing new authority to independent regulators - the chosen market watchdogs. Throughout these reforms, the independent agency paradigm remained unchallenged. But after the 2007-08 crisis, independent agency powers were seen as the problem, rather than the answer. The following Part analyzes the factors that motivated the shift.

II.

The Financial CRisis Challenges the IndePEndent AgenCy Model

On the morning of September 14, 2007, ${ }^{76}$ retail depositors lined up outside the offices of Northern Rock to retrieve their cash from the fledgling institution. It was the first bank run in the United Kingdom in over a century. ${ }^{77}$ Meanwhile, in the United States, the Federal Reserve's increased lending was failing to instill "shock and awe" that would quell fears about the expanding crisis, leading Fed Chairman Ben Bernanke and Treasury Secretary Henry Paulson to ask Congress for the momentous Troubled Asset Relief Program (TARP) package of $\$ 800$ billion. $^{78}$ In Spain, the burst of a property bubble wreaked havoc in the world of small real-estate-oriented banks. ${ }^{79}$ This was a global crisis of huge proportions.

Even before the dust settled, policy makers sought to reform banking laws to avoid future disasters, or to be more prepared if financial trouble arose again. ${ }^{80}$ The crisis had highlighted significant gaps in many countries' financial regulatory frameworks, amounting to voluminous reform agendas. To address these gaps, policy makers would have to expand government powers, even as criticism against the government bodies chiefly responsible for the supervision of the financial system was still fresh.

75. Quintyn et al., supra note 8, at 21 .

76. See Hyun Song Shin, Reflections on Northern Rock: The Bank Run That Heralded the Global Financial Crisis, 23 J. ECON. PERSP. 101, 102 (2009). For a description of the events on that day, see Rush on Northern Rock Continues, BBC News (Sept. 15, 2007, 8:37 PM), http://news.bbc.co.uk/2/hi/business/6996136.stm.

77. See Shin, supra note 76, at 101; see also Britain's Bank Run: The Bank That Failed, ECONOMIST (Sept. 20, 2007), http://www.economist.com/node/9832838.

78. See Cong. Oversight PANel, DeCEMBER Oversight RePort: TAKING Stock: What Has the Troubled AsSet Relief Program Achieved? 4 (2009), available at http://cybercemetery.unt.edu/archive/cop/20110402042852/http://cop.senate.gov/documents/cop120909-report.pdf; Edmund L. Andrews, Vast Bailout by U.S. Proposed in Bid to Stem Financial Crisis, N.Y. TIMES, Sept. 19, 2008, at A1.

79. See Banks, Bricks and Mortar: An Already Solid Financial System Faces More Consolidation, ECONOMIST (Nov. 6, 2008), http://www.economist.com/node/12501011.

80. See Treasury Summary of Regulatory Proposal, N.Y. TIMES, Mar. 29, 2008, available at http://www nytimes.com/2008/03/29/business/29regulate-text html?pagewanted=all. 
After 2008, reformers broke with the past. While they created new powers to address the regulatory shortcomings highlighted by the crisis, they granted these not to independent agencies, but to political appointees. To better understand why post-2008 reforms mark a departure from long-established regulatory paradigms, this Part presents some features of the crisis and the public narrative that surrounded it. These features compose an unusual set of circumstances that deeply undermined confidence in existing institutional structures and eluded traditional regulatory responses. Concern with regulators' failures had characterized past crises as well, but in the 2007-08 crisis, the criticism reached a strident pitch. What was so different this time around? The Sections below present the tumult of the 2007-08 period and the ensuing recessionary angst in order to lay out some preliminary hypotheses about the paradigm shift that followed.

\section{A. Criticisms of Regulatory Failures Target Multiple Agencies at Once}

The 2007-08 crisis highlighted not just one regulatory failure, but many; its successive waves reached many remote corners of the financial system, raising concerns about the system's overall governance. Consequently, these concerns did not focus on a single agency, but on many regulators, most notably the Federal Reserve, the SEC, and the OTS.

Criticisms against the Federal Reserve were loud and came from diverse quarters. The Federal Reserve, along with the Treasury Department and the FDIC, had led the United States' response to the crisis, taking many extraordinary measures that may well have been necessary. ${ }^{81}$ However, some critics feared that repeated bailouts increased moral hazard among institutions deemed "too big to fail." $" 82$ Others worried that the government's decision to let Lehman fail revealed regulatory inconsistency. ${ }^{83}$ Still others took issue with the Federal Reserve's supervision of Citigroup, a retail and investment banking behemoth that survived the crisis only after significant capital injections from the government. ${ }^{84}$ Even Chairman Bernanke, at his 2009 confirmation hearings, admitted that the Federal Reserve did not anticipate a crisis of such severity and, consequently, did not demand sufficient capital buffers from the

81. See Richard J. Herring, The Known, the Unknown, and the Unknowable in Financial Policy: An Application to the Subprime Crisis, 26 YALE. J. REg. 391, 401 (2009).

82. See Anat R. Admati et al., Liability Holding Companies, 59 UCLA L. REv. 852, 855-56 (2012) ("This promise of taxpayer bailouts is extremely dangerous for the functioning of the economy.").

83. See Jonathan G. Katz, Who Benefited from the Bailout?, 95 MinN. L. REV. 1568, 1570-79 (2011) (describing the "government's inconsistent responses to three financial failures-Bear Stearns, Lehman Brothers, and AIG").

84. See Sewell Chan \& Eric Dash, Fed Reviews Find Errors in Oversight of Citigroup, N.Y. TIMES, Apr. 8, 2010, at B1. 
institutions it supervised. ${ }^{85}$ The Federal Reserve also faced criticism for its limited consumer protection initiatives throughout the years, despite ample congressional authorization. ${ }^{86}$

As illustrious investment banks fell prey to the crisis-Bear Stearns, Merrill Lynch, and Lehman Brothers - criticism mounted against the regulator that supervised them, the SEC. The agency ran a consolidated capital supervision program, open to registered entities on a voluntary basis, but it had limited know-how in this area and its supervisory procedures suffered many defects. ${ }^{87}$ When the tipping point for a government bailout arrived, the Federal Reserve and the Treasury did not even feel the need to invite the SEC to the negotiating table. ${ }^{88} \mathrm{~A}$ few months later, Bernie Madoff's revelations tarnished the image of the SEC as an unbending enforcer of U.S. securities laws. ${ }^{89}$ The uproar against the SEC was so loud that then-Republican presidential candidate John McCain said that the Bush-appointed SEC chairman should be fired. ${ }^{90}$

The OTS, an executive agency, received the harshest criticism, as it supervised two of the most notorious financial institution failures during the crisis: AIG, the country's largest insurance company, and Washington Mutual, the country's largest thrift. ${ }^{91}$ As thrifts' business model grew closer to that of retail banks, OTS competed with other state and federal regulators to attract financial institutions to thrift charters. ${ }^{92}$ The Inspector General's report on the failure of Washington Mutual concluded that although OTS examiners identified the high risks associated with the institution's asset profile, they

85. See Nomination of the Honorable Ben S. Bernanke: Hearing Before the S. Comm. on Banking, Housing, \& Urban Affairs, 111th Cong. (2009) (statement of Ben Bernanke, Chairman, Fed. Reserve Bd.).

86. See Daniel Carpenter, Why Consumers Can't Trust the Fed, N.Y. TIMES, Mar. 17, 2010, at A27.

87. See U.S. SeC. \& EXCH. COMM'N, OfFICE OF THE INSPECTOR GEN., supra note 25, at 2-3; see also John C. Coffee, Jr. \& Hillary A. Sale, Redesigning the SEC: Does the Treasury Have a Better Idea?, 95 VA. L. REV. 707, 740-41 (2009); Robert B. Thompson, The SEC After the Financial Meltdown: Social Control over Finance?, 71 U. PITT. L. REV. 567, 569 (2010).

88. See Kara Scannell \& Susanne Craig, SEC Chief Under Fire as Fed Seeks Bigger Wall Street Role; Cox Draws Criticism for Low-Key Leadership During Bear Crisis, Wall ST. J., June 23, 2008, at A1.

89. See Jill E. Fisch, Top Cop or Regulatory Flop? The SEC at 75, 95 VA. L. REV. 785, 811 (2009). For further discussion of problems in the SEC's enforcement against broker-dealers in the period right before the financial crisis, see Gadinis, supra note 25 (finding that the SEC treatment of defendants from small and big firms was differential).

90. Laura Meckler \& Kara Scannell, McCain Says Cox Should Be Fired as SEC Chief amid 'Casino' Markets, WALL ST. J. (Sept. 18, 2008), http://online.wsj.com/article/SB12217569266865288 $1 \mathrm{html}$.

91. See Donelson \& Zaring, supra note 27, at 1779. Donelson and Zaring provide a defense for OTS, showing that OTS-supervised institutions did not, on average, fare much worse during the crisis than their counterparts supervised by other regulatory bodies.

92. See Henry N. Butler \& Jonathan R. Macey, The Myth of Competition in the Dual Banking System, 73 CORNELL L. REV. 677, 677 (1988). 
failed to take action to address them. ${ }^{93}$ According to critics, regulatory competition led to OTS's ever loosening supervision standards. President Barack Obama stated: "We've seen that structural deficiencies allow some companies to shop for the regulator of their choice. ${ }^{, 94}$ Representative Barney Frank put it even more bluntly: for institutions supervised by the OTS, he said, it "was like being regulated by the meter maid." 95 As a result, OTS was the only regulatory agency eliminated in the Dodd-Frank Act.

Criticisms against regulators are typical after a market upheaval, yet the disappointment with regulators that sunk in after 2008 was exceptionally broad and gripping. Criticism extended over multiple agencies, even agencies competing with each other to regulate institutions with similar functions, such as the Federal Reserve, the OTS, and the SEC. Instead of critics highlighting problems within a particular agency — its leadership, its rulemaking process, or its supervisory practices - they believed regulators had failed as a class. Indeed, the crisis touched a variety of issue areas under these regulators' combined jurisdiction and indicated that these agencies had collectively failed to adequately regulate the market. The problems that gave rise to the crisis involved investment banking, securitizations, and derivatives, which raised issues of systemic risk supervision under the Federal Reserve and investor protection concerns regulated by the SEC and the CFTC; disclosure and executive compensation, which the SEC typically regulates; and insurance regulation, which falls under the realm of state regulators and the OTS. The spread of the crisis across borders confirmed that regulators elsewhere, even those with much-envied consolidated powers such as the U.K. Financial Services Authority (FSA), also fell far short of expectations. Regulators' near universal misreading of the risks to the financial system deeply hurt their collective standing.

\section{B. Disillusionment with Markets' Self-Correcting Potential}

Along with leading to a loss of faith in regulators' collective ability to effectively regulate the market, the 2007-08 crisis led to loss of faith in the market's ability to correct itself. Some of the banks that collapsed in 2008 were among the most sophisticated and highly respected financial institutions in the world. How is it that they failed to understand the risks associated with the transactions that they were getting into? Perhaps no one summarized this sentiment better than former Fed Chairman Alan Greenspan: "[T] who have looked to the self-interest of lending institutions to protect shareholder's [sic] equity (myself especially) are in a state of shocked

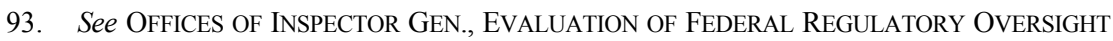
OF WASHINGTON MUTUAL BANK, Apr. 2010, 29-34.

94. See E. Scott Reckard, The Financial Crisis: U.S. Agency Is Blamed in Downey Fall, L.A. TIMES, June 18, 2009, at B1.

95. See Donelson \& Zaring, supra note 27, at 1795. 
disbelief." 96 Lloyd Blankfein, the CEO of Goldman Sachs, openly admitted market failures on behalf of his firm and other financial institutions when he stated: "We participated in things that were clearly wrong and we have reasons to regret and apologize for." In Indeed, instead of demonstrating financial acumen and self-restraint, financial institutions had adopted a winner-take-all mentality and a taste for incurring ever-higher risks. As Charles Prince, the CEO that led Citigroup up to its government bailout, stated: "[A]s long as the music is playing, you've got to get up and dance." 98

The widespread conviction that markets correct themselves over time had infiltrated regulators' understandings of their supervisory functions. The Financial Crisis Inquiry Commission concluded that U.S. financial regulators had chosen a hands-off approach in part due to their "widely accepted faith in the self-correcting nature of the markets and the ability of financial institutions to effectively police themselves." 99 In short, regulators themselves had bought into the notion that markets readjust on their own over time, and thus saw little need to actually utilize their powers to intervene.

As market players' failures eroded confidence in their abilities, calls for a more relaxed supervisory framework, ${ }^{100}$ common before 2008, gave way to arguments for a more heavy-handed regulatory approach. Even Judge Richard Posner, a prominent advocate for free markets and limited government, understood the crisis as "a failure of capitalism." "101 Others argued that deregulation in the banking sector allowed for the emergence of shadow banking, in which unregulated institutions are involved with the creation and transfer of a set of complicated financial instruments, such as credit derivatives and asset-backed securities, that link capital markets to retail investors and transmit one institution's troubles throughout the financial system. ${ }^{102}$ In the United Kingdom, Lord Turner's inquiry into the FSA's practices in the period

96. See The Financial Crisis and the Role of Regulators: Hearing Before the H. Comm. on Oversight and Gov't Reform, supra note 28; see also Edmund L. Andrews, Greenspan Concedes Flaws in Deregulatory Approach, N.Y. TIMES, Oct. 24, 2008, at B1.

97. See Graham Bowley, Taking Spin Out for a Spin, N.Y. TIMES, Nov. 22, 2009, at WK1.

98. See John Cassidy, Rational Irrationality: The Real Reason That Capitalism Is So CrashProne, New YORKER, Oct. 5, 2009, at 35.

99. See Fin. CRISIS INQUiRy COMM'N, THE FINANCIAL CRISIS INQUiRy RePORT: FINAL REPORT OF THE NATIONAL COMMISSION ON THE CAUSES OF THE FINANCIAL AND ECONOMIC CRISIS IN THE UNITED STATES xvii (2011), available at http://fcic-static.law.stanford.edu/cdn_media/fcicreports/fcic_final_report_full.pdf.

100. See, e.g., COMM. On CAPITAL MkTs. Regulation, THE COMPETITIVE Position OF THE U.S. PUBLIC EQUITY MARKET 32 (2007) available at http://www.capmktsreg.org/pdfs/The Competitive_Position_of the_US_Public_Equity_Market.pdf (describing the loss of competitiveness of the U.S. markets as a wake-up call for U.S. regulators). For a discussion of competitive pressures on U.S. regulation, see Gadinis, supra note 67, at 449.

101. Richard A. POSNER, A FAILURE OF CAPITALISM: THE CRISIS OF '08 AND THE DESCENT INTO DEPRESSION (2009).

102. See Born, supra note 26, at 232; Erik F. Gerding, The Shadow Banking System and Its Legal Origins 3-4 (Aug. 23, 2011) (unpublished manuscript), available at http://ssrn.com/ abstract=1990816. 
leading up to the crisis called for a more "intrusive" regulatory and supervisory philosophy to replace the FSA's "light-touch" regulatory approach. ${ }^{103}$ A couple of years earlier, these words were anathema to London financiers. In sum, even the most fervent believers in markets' capacity to self-regulate began to have serious doubts following the $2007-08$ crisis.

\section{Concerns About Regulatory Capture}

Scholars have long feared that special interest groups with large stakes in the regulation of their economic activities and ample resources can capture policy makers to sway regulation to their advantage. ${ }^{104}$ Some argue that industry players have an incentive to offer to regulators bribes or other payoffs up to the level of losses they expect from the implementation of a tight regulatory proposal. ${ }^{105}$ Others are more concerned about less explicit biases. Agencies often recruit professionals with significant career expertise in the industry they hope to regulate. These officials may have come to share the industry's worldview and may approach regulatory issues from the industry's perspective. ${ }^{106}$ Similar problems might arise when agency officials, tempted by higher compensation in private firms, are considering leaving the agency. With their next move in mind, agency officials might display a more favorable stance toward those they see as their future employers. ${ }^{107}$ Suspicions of regulatory capture in finance had been troubling scholars and policy makers long before the 2007-08 crisis, but these suspicions did not prevent the expansion of independent agencies' powers.

In 2008, the public discussion about regulatory capture, particularly about the impact of "revolving doors" between the industry and government, zeroed in on specific individuals with very concrete ties to industry players, such as

103. See Fin. Servis. Auth., The Turner Review: A Regulatory Response to the GLOBAL FinANCIAL BANKING CRISIS 86-92 (2009), available at http://www fsa.gov.uk/pubs/ other/turner_review.pdf.

104. See George J. Stigler, The Theory of Economic Regulation, 2 BeLl J. ECON. \& MGMT. SCI. 3 (1971). Sam Peltzman presents politicians as trading the loss of votes arising out of industry favors with political gains associated with greater financial support from that industry. Sam Peltzman, Toward a More General Theory of Regulation, 19 J.L. \& ECON. 211, 213 (1976).

105. See Jean Tirole, Hierarchies and Bureaucracies: On the Role of Collusion in Organizations, 2 J.L. ECON. \& ORG. 181 (1986); see also JEAN-JACQUES LAFFONT \& JEAN TIROLE, A THEORY OF INCENTIVES IN PROCUREMENT AND REGULATION 475 (1993).

106. See CHRISTOPHER ADOLPH, BANKERS, BUREAUCRATS, AND CENTRAL BANK POLITICS: The MYth OF NeUtRALITY (forthcoming 2013); Jeffrey E. Cohen, The Dynamics of the "Revolving Door" on the FCC, 30 AM. J. POL. SCI. 689, 690 (1986); William T. Gormley Jr., A Test of the Revolving Door Hypothesis at the FCC, 23 AM. J. POL. SCI. 665, 681 (1979). For a discussion of the potential effect of revolving doors on SEC enforcement, see Gadinis, supra note 25, at 724-26.

107. Some classic studies in this area show that procurement officials at the Department of Defense find profitable employment with defense suppliers. See GORDON ADAMS, THE POLITICS OF Defense Contracting: The Iron Triangle (1982); LeON S. ReEd, Military Maneuvers: AN ANAlysis of the InTERChange of Personnel BetweEn Defense Contractors and the DEPARTMENT OF DEFENSE (1975). 
senior government figures who had accumulated important industry experience. For example, Alan Greenspan (the former Fed Chairman and former J.P. Morgan board member) and Hank Paulson (the Treasury Secretary and a former Goldman Sachs CEO) both attracted public scrutiny. ${ }^{108}$ In addition, press reports claimed that Tim Geithner, then-president of the New York Fed, "forged unusually close relationships with executives of Wall Street's giant financial institutions" during his tenure. ${ }^{109}$ Others pointed out that industry players and financial regulators not only interacted frequently but also often behind closed doors, resulting in rulemaking that unavoidably favored industry. ${ }^{110}$ Regulators' ties to industry did not help the Federal Reserve's and the Treasury's efforts to explain their bailout choices, such as the decision to repay AIG's creditors in full. ${ }^{111}$ Senator Bernie Sanders, an Independent from Vermont, expressed the sentiment of many critics when he called for the Federal Reserve to be reformed so as "to serve the needs of working families, not just CEOs on Wall Street." 112

Critics also highlighted the financial industry's intense efforts to lobby independent regulators. The Financial Crisis Inquiry Commission connected the financial industry's lobbying efforts with regulators' reluctance to intervene in financial markets in the period leading up to the $2007-08$ crisis. ${ }^{113}$ Some critics worried that the industry's lobbying undermined effective monitoring of capital adequacy standards. ${ }^{114}$ Others argued that independent agencies' emphasis on expertise made them more receptive to industry lobbyists, who could rely on highly paid experts to formulate sophisticated arguments, and less open to struggling consumer advocacy groups. ${ }^{115}$ For all these reasons, concerns about captured regulators were a key component of the popular narrative surrounding the $2007-08$ crisis.

108. See Timothy A. Canova, Central Bank Independence as Agency Capture: A Review of the Empirical Literature, 30 BANKING \& FIN. SERVICES POL'Y REP. 11, 22 (2011); Claire Hill \& Richard Painter, Compromised Fiduciaries: Conflicts of Interest in Government and Business, 95 MINN. L. REV. 1637, 1669 (2011).

109. Jo Becker \& Gretchen Morgenson, Geithner, Member and Overseer of Finance Club, N.Y. TIMES, Apr. 27, 2009, at A1.

110. See Saule T. Omarova, Wall Street as Community of Fate: Toward Financial Industry Self-Regulation, 159 U. PA. L. REV. 411, 462-64 (2011).

111. See Peter Conti-Brown, Elective Shareholder Liability, 64 STAN. L. REv. 408, 443-44 (2012); Mark Pittman, Goldman, Merrill Collect Billions After Fed's AIG Bailout Loans, BLOOMBERG (Sep. 29, 2008, 12:41 AM), http://www.bloomberg.com/apps/news?pid=newsarchive\&sid= aTzTYtINHSG8.

112. Press Release, Sen. Bernie Sanders, The Fed Audit (July 21, 2011), available at http://www.sanders.senate.gov/newsroom/news/?id=9e2a4ea8-6e73-4be2-a753-62060dcbb3c3.

113. See The Financial Crisis and the Role of Regulators: Hearing Before the H. Comm. on Oversight and Gov't Reform, supra note 28.

114. See Arthur E. Wilmarth, Jr., The Dodd-Frank Act: A Flawed and Inadequate Response to the Too-Big-to-Fail Problem, 89 OR. L. REV. 951, 1053-54 (2011).

115. See K. Sabeel Rahman, Note, Envisioning the Regulatory State: Technocracy, Democracy, and Institutional Experimentation in the 2010 Financial Reform and Oil Spill Statutes, 48 HARV. J. ON LEGIS. 555 (2011). 


\section{Voter Interest in Financial Regulation}

Widely seen as the most important economic crisis since the Great Depression, the 2007-08 crisis had a far-reaching impact on ordinary Americans' everyday lives and generated unprecedented public interest in the intricacies of financial regulation. As a result of the crisis, many people lost their jobs, saw the price of their homes plummet, and had large parts of their pension savings disappear. Four years later, the United States is making its first steps toward a robust recovery, while other countries remain entangled in the ensuing sovereign debt crisis. A crisis of such magnitude captivated the imagination of ordinary citizens, who turned their attention to financial regulation. Delegating financial regulation to independent agencies might have been easier in an earlier era, when voters took less interest in finance.

Traditionally, financial regulation did not excite ordinary voters ${ }^{116}$ with little knowledge of the intricacies of financial markets. ${ }^{117}$ Moreover, household participation in the stock market used to be low. Even in the United States, a country with robust capital markets throughout the postwar era, household participation in the stock market stood below one-third until the 1990s. ${ }^{118}$ However, by the end of the decade, more than half of all U.S. households owned stock, either directly or indirectly (for example, through their pension accounts). ${ }^{119}$ Moreover, stock ownership, which has traditionally been very common among wealthy households, has now spread among a much broader share of the population. ${ }^{120}$ Thus, the stock market decline in 2008 hurt the savings of many Americans.

Dramatic government initiatives and violent market reactions kept the crisis in daily headlines. The eleventh-hour bailouts of Bear Stearns, Merrill Lynch, and AIG, and Lehman's spectacular collapse, increased the salience of the issue and the visibility of the main actors. In a 2008 poll on the thenevolving financial crisis, an impressive 84 percent of respondents stated that they pay at least some attention to reports about failing financial institutions such as Lehman, AIG, and Washington Mutual, with 57 percent stating that

116. In the past, financial law commentators considered the lack of interest in financial regulation on behalf of the wider public all but certain. See, e.g., Roberta Romano, The Political Dynamics of Derivative Securities Regulation, 14 YALE J. ON REG. 279, 285 (1997).

117. See Bryan D. Jones \& Frank R. Baumgartner, The Politics of ATtention: How GOVERNMENT PRIORITIZES PROBLEMS 70-73 (2005).

118. See Vicki Bogan, Stock Market Participation and the Internet, 43 J. Fin. \& QUANTITATIVE ANALYSIS 191, 192 (2008).

119. See Brian K. BUCKS ET AL., Changes In U S. FAmily FinANCES From 2004 to 2007: EVIDENCE FROM THE SURVEY OF CONSUMER FINANCES, at A27 (2009), available at http://www federalreserve.gov/econresdata/scf/files/2007_scf09.pdf.

120. Id. (reporting the percentage of families owning stock among households representing the lowest and second-lowest income-level quintiles to have increased by 3.6 and 3.2 points respectively from 1998 to 2007). 
they pay a lot of attention. ${ }^{121}$ Perhaps even more telling are the two-dollar bills that passersby taped on Bear Stearns's headquarters in downtown Manhattan, which demonstrated that the nation was following the details of the failed bank's acquisition by J.P. Morgan so closely that accounting oddities could stir public sentiment. ${ }^{122}$

Voters' increased interest in financial markets prompted politicians to react. A few months later, after Congress had failed to pass the emergency actions that the Secretary of the Treasury requested, the stock market took a deep plunge, pushing legislators to reconsider the request and pass TARP. And when details about the bonuses paid to AIG executives emerged, President Obama felt compelled to channel public anger by expressing "outrage" over these payments. ${ }^{123}$ Voters paid far greater attention to financial regulation as a result of the crisis, making it impossible for politicians seeking reelection not to think about finance.

\section{E. Independent Agencies Welcomed Politicians' Actions During the Crisis}

In many countries, efforts to contain the crisis resulted in the direct involvement of finance ministers, other high-ranking political appointees, and even prime ministers. ${ }^{124}$ In other situations, independent agencies might have resisted politicians' involvement as a threat to their autonomy. Yet, when faced with the 2007-08 financial crisis, independent agencies welcomed political involvement. Agencies' willingness to work with politicians during the crisis might have paved the way for subsequent reforms that allocated new regulatory powers to political appointees.

In the United States, Treasury Secretary Paulson was a central participant in all bailout decisions, worked closely with the Federal Reserve and the

121. More specifically, a poll commissioned by CBS news asked, "How much attention have you been paying to reports about financial institutions that have failed or are in danger of failing such as Lehman Brothers, AIG and Washington Mutual - a lot, some, not much, or none at all?" Financial Institutions, POLLING THE NATIONS, http://poll.orspub.com/search.php?PHPSESSID=5pcvcq2ilf7 ik1no2jk2koa842\&action=newsearch\&mode=poll\&sort=field\%3Atopic\%2Ca\&pollid=CBS1012008 (last visited Jan. 30, 2013).

122. See Daniel Gross, How a Lack of Faith Pounded the Markets, DaILY BEAST (Mar. 22, 2008, 8:59 AM), http://www.thedailybeast.com/newsweek/2008/03/22/how-a-lack-of-faith-poundedthe-markets html.

123. See Edmund L. Andrews \& Jackie Calmes, Obama in Effort to Undo Bonuses Granted by A.I.G., N.Y. TIMES, Mar. 17, 2009, at A1.

124. In the United States, the close cooperation between Federal Reserve Chairman Ben Bernanke and Treasury Secretary Henry Paulson was apparent throughout the crisis. See Bressman and Thompson, supra note 1, at 642. Politicians in other countries also had very direct involvement in the handling of the crisis. For example, Alistair Darling, then U.K. Chancellor of the Exchequer, pledged to guarantee all deposits in Northern Rock, which depositors had besieged for days. See Northern Rock Deposits Guaranteed, BBC NEws (Sept. 17, 2007, 8:20 PM), http://news.bbc.co.uk/2/hi/business/6999615.stm. In Spain, then-Prime Minister Zapatero himself announced the establishment of a government fund to support troubled banks. See Judy MacInnes, Spain Fund Won't Avoid Bank Consolidation, REUTERS (Oct. 8, 2008, 8:34 AM), http://www reuters. com/article/2008/10/08/financial-spain-banks-idUSL865534820081008. 
FDIC, ${ }^{125}$ and often communicated directly with regulated entities. ${ }^{126}$ In the United Kingdom, the decision to nationalize Northern Rock, the failed mortgage lender, was a central policy choice of Prime Minister Gordon Brown, who undertook to defend the decision publicly in person. ${ }^{127}$ When Fortis, a bank with a strong client base in Belgium and the Netherlands, faced increasing depositor requests for cash withdrawal, Belgian regulators advised it to look for a private partner, among other options. ${ }^{128}$ Once these efforts failed, the Belgian and Dutch governments worked together with national regulators and the European Central Bank to take over Fortis. ${ }^{129}$

In all these cases, politicians worked closely with independent regulators. Typically, independent agencies were the first to notice impending threats to financial stability. Professors Lisa Bressman and Robert Thompson studied closely how the Federal Reserve and FDIC collaborated with then-Treasury Secretary Paulson in the U.S. bailout efforts. In their view, the Federal Reserve's superior expertise helped it build a deeper understanding of the extent of the problems, the urgency of the situation, and the options available. ${ }^{130}$ But Fed Chairman Bernanke welcomed the political backing that the White House could offer in order to ensure the support of the financial services sector, the public, and Congress. ${ }^{131}$ The White House's political clout

125. See, e.g., ANDREW RosS SORKIN, TOO BIG TO FAIL: THE INSIDE STORY OF HOW WALL STREET AND WASHINGTON Fought TO SAVE THE FinANCIAL SYSTEM-AND THEMSELVES 394-95 (2009) (describing communications between Ben Bernanke, Henry Paulson, and Tim Geithner among others, on AIG's bailout). Sheila Bair, then-chairman of the FDIC and another participant in some of these meetings, refers to the close cooperation between the Treasury and the Federal Reserve, which sometimes left the FDIC at the sidelines. See Gretchen Morgenson, Questions from a Bailout Witness, N.Y. TIMES, Oct. 14, 2012, available at http://www nytimes.com/2012/10/14/business/sheila-bairsbig-questions-about-bank-bailouts html (reviewing SHEILA BAIR, BULL BY THE HORNS (2012)).

126. See, e.g., Liz Rappaport, Lewis Testifies U.S. Urged Silence on Deal, Wall St. J., Apr. 23, 2009, at A1 (discussing allegations that Treasury Secretary Paulson pressured Bank of America CEO Ken Lewis).

127. See Helene Mulholland, Gordon Brown's Press Conference - Live, GUARDIAN (Feb. 18, 2008), http://www.guardian.co.uk/politics/blog/2008/feb/18/gordonbrownspressconference; Adam Smith, Will Northern Rock Sink Brown?, TIME (Feb. 18, 2008), http://www.time.com/time/business/ article $/ 0,8599,1714286,00 \mathrm{html}$.

128. See Philip Blenkinshop \& Michele Sinner, Belgium, Luxembourg Scramble to Sell Fortis, REUTERS (Oct. 4, 2008, 3:46 PM), http://www reuters.com/article/2008/10/04/us-fortisidUSTRE4931L120081004?feedType=RSS\&feedName=businessNews (suggesting that regulators were examining a sale to private parties and a nationalization as alternatives at the same time); Ulrich Volz, Europe Needs a United Approach to the Credit Crunch, WALL ST. J., Oct. 7, 2008, at A27.

129. Blenkinshop \& Sinner, supra note 128; Volz, supra note 128.

130. See Bressman \& Thompson, supra note 1, at 630.

131. Federal Reserve Chairman Ben Bernanke took many extraordinary steps to stem the spread of the crisis from institution to institution, but was also working closely with then-Treasury Secretary Paulson toward a plan for a broad government intervention, concluding that the best solution was to buy hard-to-sell mortgage backed securities. Bernanke and foreign central bankers were concerned about Congress's ability to act quickly enough on that plan. To win Congress's cooperation, Bernanke sought Paulson's assistance. Andrew Ross Sorkin et al., 36 Hours of Alarm and Action as Crises Spiraled, N.Y. TIMES, Oct. 2, 2008, at A1 ("Mr. Bernanke told Mr. Paulson during a conference call: 'You have to go to Congress. This is pervasive.' Mr. Paulson agreed."). Paulson confirmed that, 
proved essential for the Federal Reserve, as many questioned whether unelected bureaucrats should have the extraordinary power to wield financial instruments with a value upward of $\$ 800$ billion dollars. ${ }^{132}$ Moreover, the Treasury's active role helped pool information and coordinate actions with other regulatory agencies. ${ }^{133}$ Thus, the cooperation between independent agencies and politicians in 2008 provided a blueprint for combining actions by two government bodies typically perceived as antithetical.

In summary, prior to the 2007-08 crisis, the agency independence paradigm dominated financial regulation in the United States and in many other jurisdictions. International bodies such as the IMF and the Basel Committee promoted agency independence as the best way to ensure expert decision making and a stable regulatory environment. Criticisms of the independent agency model had surfaced prior to the financial crisis. But following the crisis, critics voiced concerns about regulatory failures, markets' limited selfcorrecting potential, and the risk of industry capture more forcefully than before. These criticisms often came from unexpected sources, including industry and government leaders who had previously taken contrary positions. Disappointment with independent agencies, along with voters' heightened interest in financial regulation and a cooperative relationship between political appointees and agency bureaucrats during the crisis, paved the way for a new regulatory paradigm.

III.

\section{DATA AND INDEX FORMULATION}

This Article shows that, following the 2008 financial crisis, reformers assigned new powers not to independent agencies but to political appointees. This development occurred in many jurisdictions almost simultaneously, and it represented a significant departure from past regulatory paradigms. To demonstrate the wide-ranging impact of the paradigm shift, the Article presents data documenting regulatory reforms in the developed world's most important financial centers. This Part presents the Article's methodology and data collection process, while the next Part presents its main findings.

To analyze policy makers' response to the crisis, this Article tracks reforms in banking supervision laws and regulations in key jurisdictions around the world. The data presented below cover the following jurisdictions: the United States, Canada, Mexico, the United Kingdom, France, Germany,

when hearing Bernanke's request for his active involvement before Congress, he responded positively. Joe Nocera \& Edmund L. Andrews, Running a Step Behind as a Crisis Raged, N.Y. TIMES, Oct. 23, 2008, at A1. ([As Paulson narrates the story:] "Ben said, 'Will you go to Congress with me?' [referring to the Federal Reserve Chairman, Ben S. Bernanke]. "I said: 'Fine, I'm your partner. I'll go to Congress."').

132. See Bressman \& Thompson, supra note 1 , at 626 .

133. See id. at 631 . 
Switzerland, Spain, Denmark, Japan, South Korea, Italy, Ireland, Belgium, and Australia. This Article focuses on developed markets, whose banking sectors were the origin of the crisis, rather than emerging markets, where the crisis arrived only later and affected mostly international trade financing. ${ }^{134}$ Developed economies' financial sectors constitute the central organs of the global financial system, commanding over 80 percent of world financial market capitalization. ${ }^{135}$ Moreover, whereas emerging economies present significant variation in levels of democratization and institutional structures, agency independence is meaningful only in the context of a strong democratic regime that guarantees separation of powers.

For each jurisdiction's banking laws, this Article presents the results of primary legal research by lawyers who received their training in that jurisdiction. ${ }^{136}$ All local lawyers answered a list of about forty questions that outline the key functions of a banking supervisory regime, ${ }^{137}$ including prudential oversight, day-to-day supervision, deposit insurance, lender-of-lastresort activities, and liquidation. For each function, the questionnaire identifies responsible authorities, procedures for the appointment and termination of these authorities' chairmen and board members, and areas of overlap among multiple authorities. More specifically, the questionnaire explores various ways in which the national elected government has acquired authority over key issues of banking supervision. In the U.S. context, these political bodies include Congress and the President, as well as officials directly appointed by the President. In parliamentary democracies, these bodies include the office of the prime minister and the ministry of finance.

To capture change in various authorities' decision-making powers, this Article compares each jurisdiction's precrisis and postcrisis laws. Local lawyers completed the questionnaires for two points in time: first, based on the law as it stood on April 30, 2007, and second, based on the law as it stood reformed by December 1,2010 . The first date marks the beginning of the subprime mortgage crisis in the United States, when interest rates increased and housing prices started their decline. ${ }^{138}$ The first class actions based on

134. See Michael Dooley \& Michael Hutchinson, Transmission of the U.S. Subprime Crisis to Emerging Markets: Evidence on the Decoupling-Recoupling Hypothesis, 28 J. INT'L MONEY \& FIN. 1331, 1332 (2009).

135. See Philip R. Lane \& Gian Maria Milesi-Ferretti, The Drivers of Financial Globalization, 98 AM. ECON. REV. 327, 327-28 (2008).

136. Local lawyers' memoranda are available to readers upon request.

137. See Appendix I.

138. See U.S. CONG. JoInt ECON. COMm, SubPrime Mortgage Market Crisis Timeline (2008), http://www.jec senate.gov/public/?a=Files Serve\&File_id=4cdd7384-dbf6-40e6-adbc-789f691 31903; see also Mortgage Rates Move Sharply Higher, CNN (May 24, 2007, 5:08 PM), $\mathrm{http} / / /$ money.cnn.com/2007/05/24/real_estate/mortgage_rates/index htm?postversion=2007052411. 
mortgaged-backed securities were filed in February 2007. ${ }^{139}$ By the end of 2010, the acute market drops had given way to stabilized prices, ${ }^{140}$ and legislators were finalizing changes in their regulatory structures. The United States, which has a lengthy lawmaking process that involves two congressional chambers and separate congressional committees, had completed its reform by July 2010, when President Obama signed the Dodd-Frank Act into law. ${ }^{141}$ Although some reforms in banking regulation introduced during this period might not have been directly related to the financial crisis, the crisis dominated the attention of policy makers and voters throughout this time. ${ }^{142}$

To facilitate comparison between the precrisis and postcrisis laws in each jurisdiction, this Article synthesizes questionnaire responses to an index of fifteen key powers, described in Table 1. For each area of banking supervision, the index identifies direct powers granted to finance ministries or their equivalents in all stages of the regulatory process, including the powers to make rules for classes of entities, to make specific decisions against particular banks, and to implement these decisions. Moreover, the index also records politicians' powers to appoint and fire members of the regulatory body otherwise responsible for each function.

For each power, jurisdictions get a score from 0 to 1 . The jurisdiction receives a score of 1 when the power belongs to a politically controlled body, denoted in the index by FM (finance ministry), or when a politically controlled body may veto the agency's decision. On the other hand, when the power is held by an independent agency or another body not directly accountable to the electorate-such as a court or a court-appointed liquidator-the jurisdiction receives a score of 0 . If independent agencies and politically controlled bodies hold the power collectively, but the independent agencies can exercise the power without the consent of politically controlled bodies, and vice versa, then the jurisdiction receives a score of 0.5 . As a result, the lowest score for a jurisdiction is 0 , suggesting that no elected politician can authorize specific outcomes in banking regulation, and the highest score for a jurisdiction is 15 , reflecting maximal political control. Table 1 presents the fifteen questions that constitute the index.

139. See Jennifer E. Bethel et al., Law and Economics Issues in Subprime Litigation 470 (Harv. Law Sch. John M. Olin Ctr. for Law, Econ. \& Bus. Discussion Paper Series, Paper No. 612, 2008), available at $\mathrm{http}: / / \mathrm{lsr}$ nellco.org/harvard olin/612.

140. For example, the Case/Shiller Index of National Home Prices remained at 2008-09 levels without suffering subsequent major drops. See S\&P/Case-Shiller Home Price Indices: 2010, A Year in Review, MCGRAw-HILL COS. (Jan. 11, 2011), http://www.standardandpoors.com/indices/ index-research/en/us/?type=All\&category $=$ Economic.

141. Helene Cooper, Obama Signs a Contentious Overhaul of the U.S. Financial System, N.Y. TIMES, July 21, 2010, at B3.

142. Local lawyers were asked to provide some background on any reforms introduced; each lawyer referred to the crisis as at least one of the motivations behind the changes. 
TABLE 1: Index of fifteen questions regarding political influence in banking supervision

Questions 20072010

1. Does the $\mathrm{FM}^{143}$ have direct powers in prudential supervision?

2. Does the FM appoint the majority of prudential authority members?

3. Can the FM fire prudential authority members?

4. Does the FM appoint the majority of supervisory authority members?

5. Can the FM fire supervisory authority members?

6. Does the FM appoint the majority of deposit insurance authority members?

7. Can the FM fire deposit insurance authority members?

8. Is FM consent required for key prudential authority decisions?

9. Is FM consent required for key supervisory authority decisions?

10. Can FM reverse the decisions of prudential supervisors?

11. Can FM issue rulemakings that affect prudential supervisors' decisions?

12. Is FM consent required for resolution of a qualified institution?

13. Is the resolution decision shielded from judicial review?

14. Is FM involved in the resolution process?

15. Is FM responsible for extending loans during the resolution?

\section{Total}

\section{IV. \\ MAIN FINDINGS}

\section{A. Overall Increase in Political Influence over Banking Supervision}

Almost all jurisdictions that reformed their banking supervision laws between 2007 and 2010 moved in the direction of increasing politicians' influence. ${ }^{144}$ Figure 1 presents the index scores for the countries included in the

143. "FM" stands for finance ministry or the equivalent.

144. See infra Figure 1. 
dataset. $^{145}$ The dot marks each jurisdiction's score in 2007, and the arrow shows the change, if any, as of 2010. The figure demonstrates a striking finding: no jurisdiction reformed its banking laws so as to enhance the independence of regulators, as prior regulatory paradigms would have suggested. The departure from these prior paradigms becomes even starker if one considers that those who made changes between 2007 and 2010 include almost all the leading jurisdictions for global finance - the United States, the United Kingdom, France, and Germany. The only jurisdiction that revamped its regulatory structure but did not increase politicians' influence is Switzerland, whose federal structure is highly idiosyncratic and lacks an executive official with centralized power, such as a president or prime minister. ${ }^{146}$ Overall, the trend toward strengthening the role of politicians over banking supervision is clear. $^{147}$

The apparent appeal of political influence in banking becomes nearly universal when one considers the characteristics of the countries that did not introduce any reforms between 2007 and 2010. Most nonreformer countries already had a high score on the political influence index even before 2007. The only jurisdiction with a low political influence index score that did not introduce reforms is South Korea, which was considering legislation that would have deregulated the financial industry but scrapped the legislation. ${ }^{148}$ The

145. Appendix I presents the detailed index breakdown for each individual jurisdiction, based on local laws as they stood in 2007 and 2010. It also includes references to the main pieces of reform legislation in each jurisdiction.

146. See AREND LiJPHART, PATTERnS OF DEMOCRACY: GOVERNMENT FORMS AND PERFORMANCE IN THIRTY-SIX COUNTRIES 34-36 (2d ed. 2012), for a discussion of the idiosyncrasies of the Swiss federal system. See generally Fridolin M.R. Walther, The Swiss Legal System: A Guide for Foreign Researchers, 29 INT'L J. LEGAL INFO. 1 (2001), for background information on the operation of the Swiss government.

147. Upon observing this strong trend toward increasing the role of politicians in financial regulation, some may wonder whether postcrisis reforms sparked a process of policy diffusion, whereby some countries introduce a change in their laws that other countries later emulate. Diffusion processes in law reforms are well documented and studied. See Katerina Linos, Diffusion Through Democracy, 55 AM. J. POL. SCI. 678 (2011) (arguing that voter familiarity with prominent countries prompts leaders to emulate these countries' policies); Christopher R. Way, Political Insecurity and the Diffusion of Financial Market Regulation, 598 ANNALS AM. ACAD. POL. \& SoC. SCI. 125 (2005) (arguing that leaders emulate other countries' financial liberalization policies hoping for a domestic market boom that will keep them in power). However, the postcrisis reforms discussed above do not seem to fall in line with diffusion patterns. All reforms occurred rapidly after the crisis, leaving little time for cross-border exchange of ideas. Moreover, reforms are closely tied to the institutional idiosyncrasies of each jurisdiction, rather than propagating a common model. Overall, these reforms seem like countries' responses to a common shock - the financial crisis - instead of a result of gradual emulation.

148. See Government Faces Criticism for Deregulation Bills, HANKYOREH (Sept. 22, 2008, 1:05 PM), http://english hani.co kr/arti/english_edition/e_business/311591 html. Eventually, South Korea passed a law, the Capital Market Consolidation Act of 2009, which permitted greater integration among banking, insurance, and brokerage companies. This law did not change the structure of banking supervision. For a discussion of the law, see Entering the South Korean Financial Services Market, PRICEWATERHOUSECOOPERS (2008), http://www.pwc.com/en_GX/gx/financial-services/pdf/ pwc_fs_manda_korea.pdf. 
Appendix includes a detailed breakdown of each jurisdiction's index scores before and after recent reforms.

\section{FIGURE 1: Change in political influence over banking supervision, 2007-10}

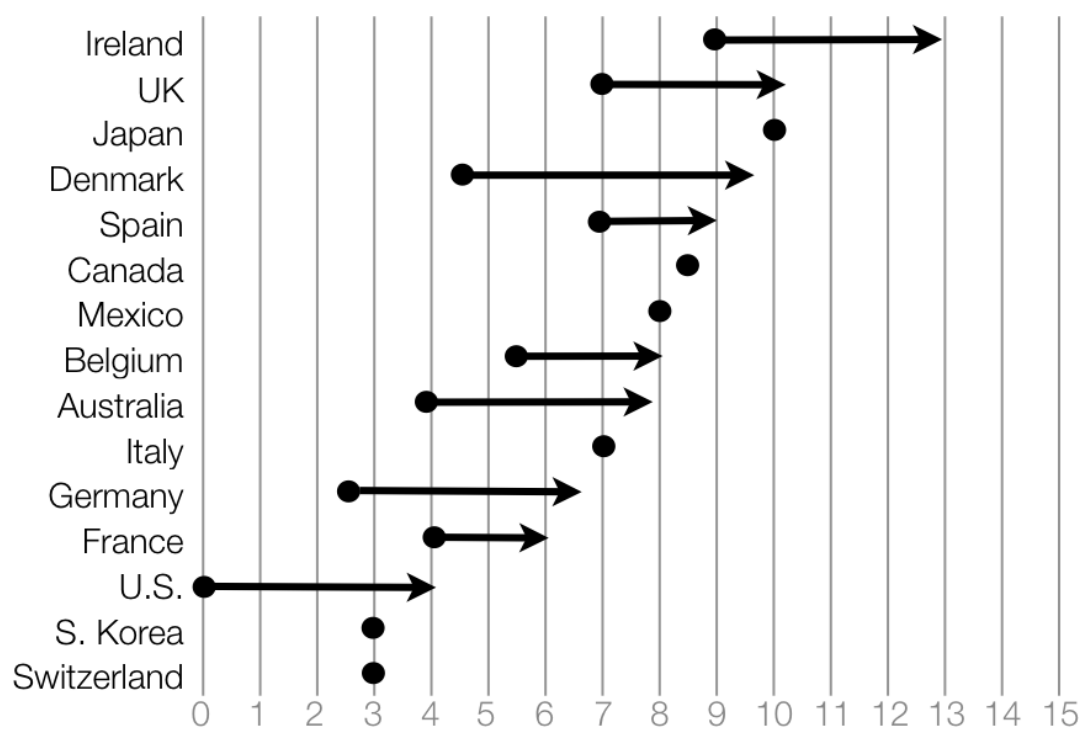

The political bodies that emerge as clear winners from these reforms are finance ministries. In most jurisdictions, the finance ministry exercises new powers, although in some instances the chief executive officer-the prime minister or president-also becomes involved. ${ }^{149}$ As Figure 1 shows, the increase in politicians' powers was sizeable, representing a shift of about 3.4 points on this index on average. In sum, there is a new player in global financial regulation, and it is the finance ministries.

Even as reforms have tended to shift authority in the same direction, variation in political influence over banking regulation in various countries remains significant. In 2007, scores ranged from 0 to 10 , with a mean of 5.7 and a standard deviation of 2.8. In 2010, scores ranged from 3 to 13, with a mean of 7.9 and a standard deviation of 2.5. Despite these important common trends, widespread differences remain among jurisdictions in the dataset regarding the ultimate level of political influence in their banking laws and the types of powers that politicians possess. For example, a score of 4 - the United States' score - suggests that politicians have input on some key issues,

149. For example, in the United States, the Dodd-Frank Act (partially codified at 12 U.S.C. $\S$ 5383(a)) requires the Treasury Secretary to consult with the President before determining whether to intervene in a failing institution. See infra Part V.B. 
including the decision to liquidate a failing bank. ${ }^{150}$ Meanwhile, a score of 9Spain's score - suggests that, in addition to their powers over these key issues, politicians can exercise influence over banking regulation in many other direct or indirect ways, such as by appointing and firing agency officials or by passing specific rules. ${ }^{151}$ The remainder of this Part analyzes these findings in greater detail.

\section{B. New Areas of Political Influence: Resolution Authority and Prudential Regulation}

Postcrisis reforms grant to politicians powers not only to intervene in failing institutions at times of crisis but also to make critical decisions for banks during regular times, before any clouds of trouble arise on the horizon. Figure 2 provides a breakdown of politicians' increased powers in banking regulation across the following issue areas: prudential authority (e.g., granting banking licenses and reviewing capital adequacy), resolution (e.g., determining whether to intervene, take over, or liquidate a failing bank), supervisory authority (e.g., day-to-day monitoring of accounting records and practices), and deposit insurance (e.g., guaranteeing payouts to depositors). Each bar represents the number of jurisdictions that gave politicians a particular power. For example, the first graph indicates that, in 2007, seven of the fourteen countries included in the survey allowed politicians direct authority in prudential supervision. By 2010 , eleven of the fourteen countries gave politicians these powers.

150. For example, any intervention to a systemically important financial institution (apart from a licensed retail bank) in the United States occurs only with the approval of the Secretary of the Treasury. See infra Part V.B.1-2.

151. For example, Spain's Fund for Orderly Bank Restructuring is governed and managed by a governing committee, the members of which are appointed by the Minister of Economy and Finance (currently the Minister of Economy and Competitiveness). Law on Bank Restructuring, art. 3(1) (B.O.E. 2009, 155) (Spain). 
FIGURE 2: Politicians' powers across issue areas, 2007-10

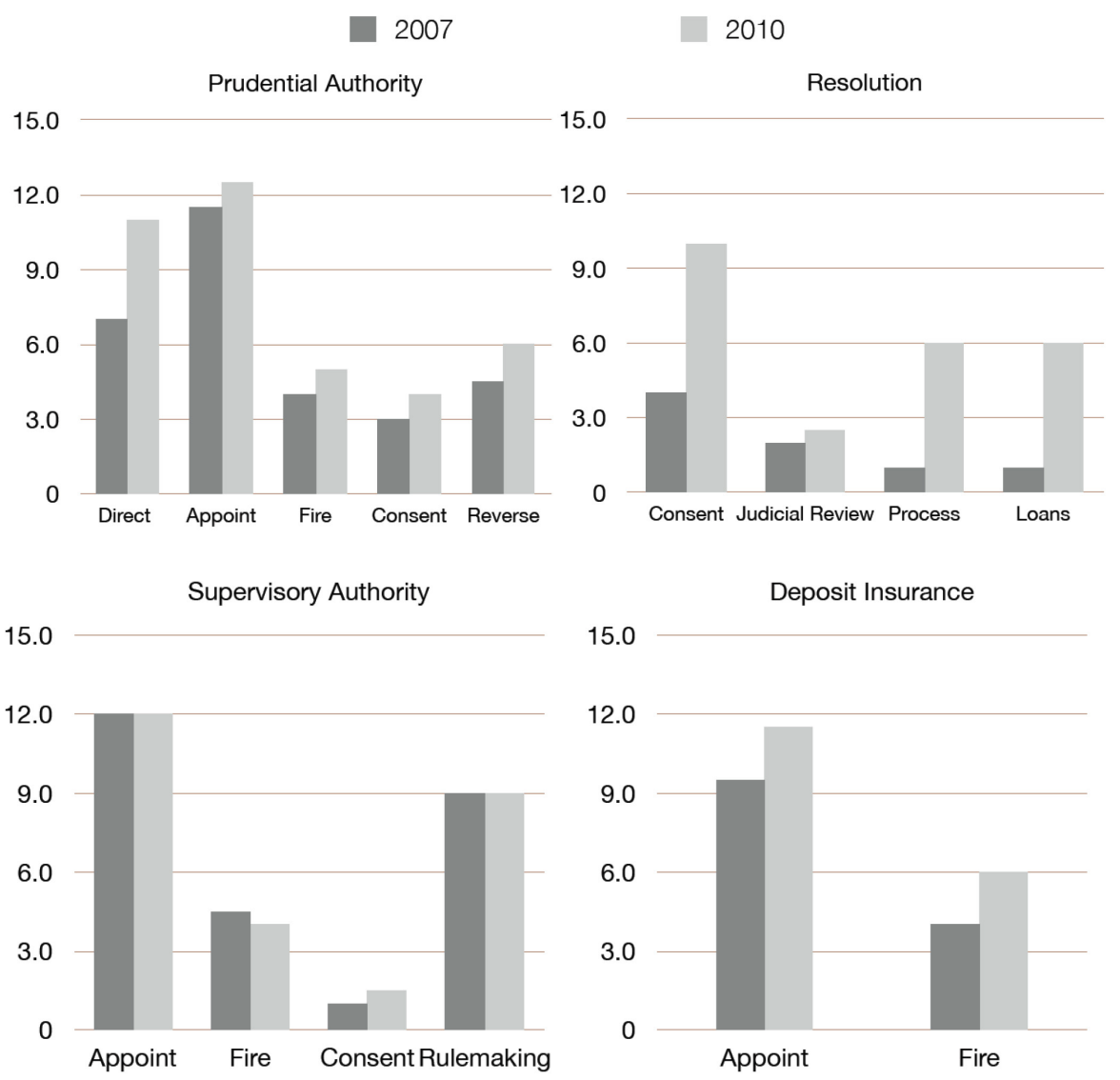

The ability to lead a financial institution to resolution swiftly was at the heart of the 2007-08 crisis, and thus a main focus of postcrisis reforms. The failures or near failures of many large banks and the subsequent bank runs in some jurisdictions revealed regulatory gaps in their pre-2007 regimes. ${ }^{152}$ Thus, it was hardly surprising to see politicians increase their involvement with resolution decisions. However, it was quite unexpected to see politicians increase their say on issues of prudential authority, such as whether to license a new bank. This change suggests that politicians were not content to simply sit

152. For example, Bear Stearns failed despite the bank strictly following its regulatory capital requirements. See Stephen Morris \& Hyun Song Shin, Financial Regulation in a System Context in Economic Activity, 2008 BROOKINGS PAPERS ON ECON. ACTIVITY 229, 231; see also Eric S. Rosengren, President \& CEO, Fed. Reserve Bank of Bos., Address at RiskCapital 2009: The Global Risk Regulation Summit: The Roles and Responsibilities of a Systemic Regulator (June 29, 2009) (transcript available at http://www.bos frb.org/news/speeches/rosengren/2009/062909 htm). 
back and deal with a crisis when it arose but also wanted a greater role in setting the terms of entrance for market players. Increased prudential authority provides politicians with the power to determine certain terms for entering and competing in the lucrative business of finance. It also provides them with the information necessary to determine an institution's general health and good standing, and to identify early warning signs of trouble. Because prudential supervision empowers regulators to require additional capital, it can directly affect an institution's profitability. ${ }^{153}$ From a systemic-regulation and capitaladequacy perspective, resolution authority and prudential supervision are the two most important regulatory areas for financial institutions. Consequently, increasing politicians' powers in these areas could not only enable them to better protect ongoing market stability but also significantly impact financial institutions' operations.

\section{New Types of Powers}

Postcrisis reforms depart from prior paradigms in another important way. Prior to 2007, politicians exercised their influence over banking regulation mostly indirectly: for example, by appointing people who shared politicians' views and preferences to head banking regulators. ${ }^{154}$ While appointees were responsible for making actual supervisory decisions, politicians could only observe developments from a distance, as their power to remove appointees and fire regulators was significantly curtailed. Generally, finance ministries had few powers to make specific decisions in banking supervision, limited mostly to the decision to establish a banking institution. ${ }^{155}$ Particularly in jurisdictions with strong traditions of independent central banking, such as the United Kingdom, politicians had few direct powers in banking regulation. ${ }^{156}$ As Figure 3 shows, in 2007, appointment and removal powers exceeded direct powers in banking regulation in all jurisdictions in the sample, except for Germany and Spain. ${ }^{157}$ Overall, politicians acted mostly behind the scenes.

153. See generally Ash Demirgüç-Kunt \& Harry Huizinga, Determinants of Commercial Bank Interest Margins and Profitability: Some International Evidence, 13 WORLD BANK ECON. REV. 379 (1999).

154. Officials engage in considerable political wrangling surrounding regulatory appointments. See, e.g., Robert Schmidt \& Otis Bilodeau, SEC's Nazareth Is Democrats' Choice for Commissioner, BLOOMBERG (May 18, 2005, 10:02 AM), http://www.bloomberg.com/apps/news?pid= newsarchive\&sid=adXMPIFb0zlM\&refer=us.

155. See, e.g., Masaki Yagyu, Securities Activities of Japanese Banks Under the 1993 Japanese Financial System Reform, 15 Nw. J. INT'L L. \& BUS. 303, 304 (1994) (providing an example of the licensing powers of the ministry of finance in Japan).

156. See Heidi Mandanis Schooner \& Michael Taylor, United Kingdom and United States Responses to the Regulatory Challenges of Modern Financial Markets, 38 TEX. INT'L L.J. 317, 332 (2003) (suggesting that lines of accountability operated through the treasury's appointment and removal powers).

157. Politicians' powers in the jurisdictions studied amounted to a total of thirty indirect powers compared to a total of 21.5 direct powers. See infra Figure 4. 
Postcrisis reforms threw politicians to the foreground. The powers of politically controlled bodies over the banking system are now mostly direct and include the abilities to oversee financial institutions' compliance with prudential requirements (such as capital adequacy standards), ${ }^{158}$ to provide consent in order to have a financial institution declared insolvent, ${ }^{159}$ and to oversee the liquidation of a financial institution. ${ }^{160}$ While politicians sometimes share their authority with regulators (typically in the form of veto rights), in other cases politicians now have exclusive authority. ${ }^{161}$ After the crisis, the only jurisdictions where politicians hold more indirect powers than direct ones are Mexico, Australia, Belgium, and interestingly, Germany, which reshuffled the appointment process for its regulatory body, Bundesanstalt für Finanzdienstleistungsaufsicht (BaFin) [Federal Financial Supervisory Authority]. South Korea remains the only jurisdiction where politicians have no direct powers over banking supervision. ${ }^{162}$ Figure 3 demonstrates the shift from indirect to direct powers after the crisis.

158. In Ireland, each bank involved in retail deposits must maintain a deposit guarantee with the central bank. The Ministry of Finance, upon the advice of the Central Bank, sets the deposit guarantee rate, different for every bank, by taking into account each bank's internal compliance (among other factors). See Financial Services (Deposit Guarantee Scheme) Act 2009 (Act No. 13/2009) (Ir.), available at http://www.irishstatutebook.ie/2009/en/act/pub/0013/index html.

159. Requiring the consent of the finance minister or treasury secretary in order to intervene in a failing financial institution is a common reform that was introduced in six jurisdictions by 2010: the United States, the United Kingdom, Spain, Denmark, Belgium, and Ireland. See Appendix I.

160. For example, a bank in need of government support must provide a restructuring plan and obtain the approval of the Ministry of Finance. See Law on Bank Restructuring, art. 7 (B.O.E. 2009, 155) (Spain).

161. Typically, politicians have exclusive authority when deciding whether to extend financial assistance to a failing institution, under what conditions, and up to what amount. See, e.g., infra Part V.B.5 (Treasury has sole authority to provide funding in the context of a receivership under DoddFrank's Orderly Liquidation Authority).

162. South Korean politicians still have indirect power over banking regulation, as the Finance Minister appoints the majority of prudential authority members, as well as the majority of supervisory authority members, under the Act on the Establishment, Etc. of Financial Services Commission, Act No. 10303, May 17, 2010, art. 4(2)-(3) (S. Kor.). 


\section{FIGURE 3: Shift from indirect to direct powers in postcrisis reforms}

Appoint/Fire

Powers in 2007

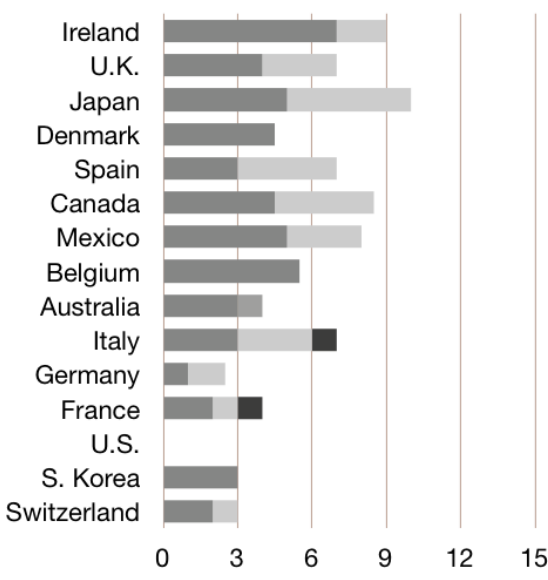

No court review

Loans

Powers in 2010

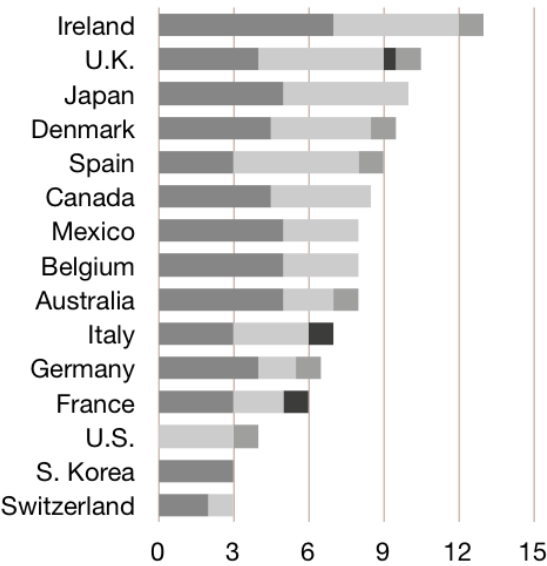

Among the various direct powers politicians gained, two stand out: the power to extend credit to ailing financial institutions - essentially, to bail them out - and the power to intervene in a financial institution without any judicial review of that decision. ${ }^{163}$ Figures 3 and 4 indicate which jurisdictions have expressly granted these powers to finance ministries by using the labels "Loans" and "No court review." By extending credit to ailing financial institutions, governments can help them to continue their businesses, either to avoid disruptions in the market during their liquidation, or to help institutions sell themselves later to private investors. Much criticism of postcrisis reforms has focused on politicians' new bailout powers, as bailouts can create a comfortable fallback option for big financial institutions and thus increase moral hazard. ${ }^{164}$ As Figure 4 shows, bailout power is a common feature of postcrisis reforms, which have uniformly given the power to political bodies rather than independent agencies. Some jurisdictions, such as the United States ${ }^{165}$ and Spain, ${ }^{166}$ have explicitly required the government to explore the

163. Between 2007 and 2010, finance ministers gained the power to provide loans to ailing institutions in six different jurisdictions: the United States, the United Kingdom, Germany, Spain, Denmark, and Ireland. See Appendix I.

164. See Lisa Lamkin Broome, The Dodd-Frank Act: TARP Bailout Backlash and Too Big to Fail, 15 N.C. BANKING INST. 69 (2011); see also Lammertjan Dam \& Michael Koetter, Bank Bailouts and Moral Hazard: Evidence from Germany, 25 REV. FIN. STUD. 2343, 2344 (2012); Kenneth Rogoff, IMF Proposals Get the Big Picture Right, GuARDIAN (May 1, 2010, 11:00 AM), available at http://www.guardian.co.uk/commentisfree/2010/may/01/imf-tax-proposals-banks?INTCMP=SRCH; David Lawder, U.S. Bailout Program Increased Moral Hazard: Watchdog, ReUTERS (Oct. 21, 2009, 1:30 AM), http://www reuters.com/article/2009/10/21/us-usa-bailout-watchdog-idUSTRE59K0UQ 20091021.

165. See infra Part V.B.3. 
possibility of selling an ailing institution to investors before regulators take control. Others, like Germany ${ }^{167}$ and Denmark, ${ }^{168}$ reserve the final say for the government, but allow private parties greater initiative. In both cases, politicians are now the ultimate arbiters of bailout decisions.

\section{FIGURE 4: Types of new powers politicians exercise in postcrisis reforms}

Appoint/Fire Direct $\square$ No court review $\square$ Loans

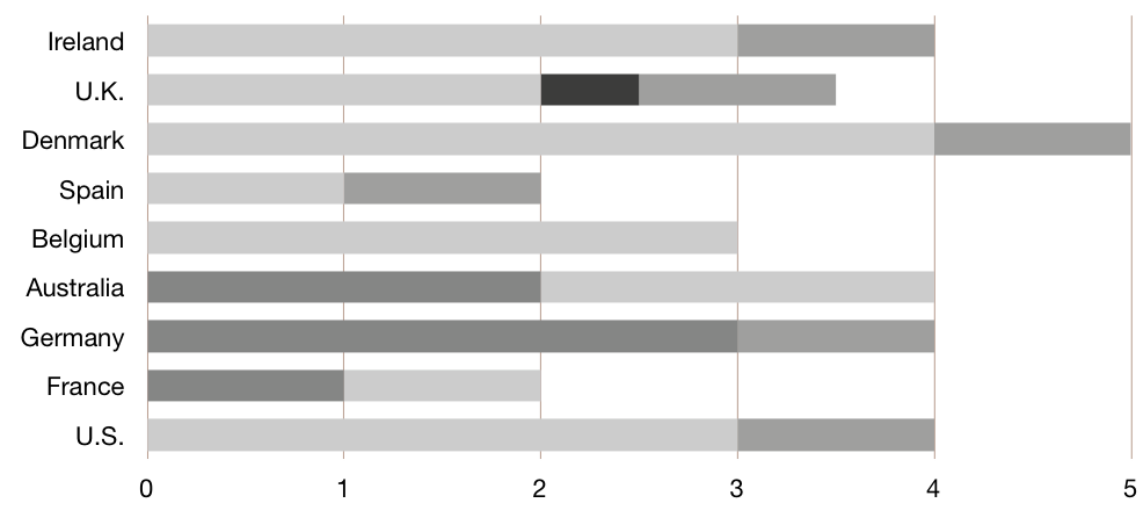

D. Consolidation, Fragmentation, and Reorganization of Regulatory Agencies

Before the crisis, complaints about fragmentation of regulatory authority across multiple administrative bodies were common among scholars, policy makers, and regulators alike. ${ }^{169}$ These complaints became even more pressing

166. See Law on Bank Restructuring, art. 6 (B.O.E. 2009, 155) (Spain) (a private sector solution is part of Spain's restructuring plan and requires the failing bank to first gain the Ministry of Finance's and the Bank of Spain's approval).

167. German reforms explicitly contemplate the sale of the healthy parts of a failing institution's business. See Bankenrestrukturierungsgesetz [Bank Restructuring Act], Dec. 14, 2010, BGBL. I at 63 1900, art. 2 (Ger.).

168. See Art. 16(e)-(i), Liquidation of Distressed Financial Institutions Act, June 1, 2010 (Den.) (commonly referred to as "Bank Package 3") (allowing a government fund to take over a failing financial institution and transfer the viable parts of the business to a new legal entity in order to sell them to private investors).

169. Scholars, regulators, and policy makers have long debated the merits and pitfalls of the U.S. dual banking system. Among the strongest proponents of the dual banking system is Kenneth Scott, who analyzed the institutional interplay between banks, regulators, and dongressional reformers. See Kenneth E. Scott, The Dual Banking System: A Model of Competition in Regulation, 30 STAN. L. REV. 1, 9 (1977). Heidi Schooner notes the states' "continuing opportunity to serve as laboratories of innovation." See Heidi Mandanis Schooner, Recent Challenges to the Persistent Dual Banking System, 41 ST. LouIS U. L.J. 263, 264 (1996). On the other hand, Butler and Macey argued that the dual banking system survives only "because it provides an efficient structure for extracting the maximum amount of economic rents from political supplicants." See Butler \& Macey, supra note 92, at 679. Howell Jackson notes the fragmentation of resources at the budget and personnel levels. See Howell E. Jackson, Variation in the Intensity of Financial Regulation: Preliminary Evidence and Potential Implications, 24 YALE J. ON REG. 253, 266 (2007). 
in 2008, when no single regulator had a comprehensive understanding of the highly interconnected financial system, and thus assessing the systemic implications of any institution's collapse proved exceedingly hard. ${ }^{170}$ In light of such strong criticism, both before and during the 2007-08 crisis, one would expect postcrisis reformers to consolidate multiple regulators into bigger entities that would have a more holistic view of the financial system. In fact, as this Article shows below, only some countries chose to consolidate existing financial regulators.

Even in countries where consolidation took place, it was only partial and left broad swaths of the financial system under the jurisdiction of multiple regulators. Only one country, Switzerland, actually merged regulators active in different areas of the financial system-banking, insurance, and money laundering. ${ }^{171}$ Switzerland is also the only jurisdiction where reforms did not result in an increase of politicians' powers. ${ }^{172}$ Two jurisdictions, Belgium and Ireland, folded their separate banking regulators into their central banks. ${ }^{173}$ Both countries had experienced significant upheavals in their banking sectors, ${ }^{174}$ and both also increased the powers of politicians in banking supervision. ${ }^{175}$ Other countries consolidated some of their existing regulators but allowed them to maintain separate existences from the countries' central banks. France merged its prudential and day-to-day banking supervisors into a single agency, the Autorité de Contrôle Prudentiel (ACP), to create one strong banking regulator. ${ }^{176}$ The United States eliminated the OTS and folded its

170. See, e.g., Editorial, Regulator Shopping, N.Y. TIMES, May 21, 2009, at A34.

171. This new agency, FinMa, was created under the Bundesgesetz über die Eidgenössische Finanzmarktaufsicht [FINMASA] [Federal Financial Market Supervision Act] June 22, 2007, SR 956.1 (Switz.).

172. See supra Figure 1; see also Appendix I.

173. Belgium follows a "twin peaks" approach, with the central bank responsible for prudential supervision and a new regulator, the Financial Services Markets Authority, responsible for market and consumer-related issues. See Loi modifiant la loi 2 août 2002 relative à la surveillance du secteur Financier et aux services financiers [Law Amending the Law of 2 August 2002 on the Supervision of the Financial Sector and Financial Services] of July 2, 2010, Moniteur Belge [M.B.] [Official Gazette of Belgium], Sept. 28, 2010, 59140 (Belg.). For further discussion, see NAT'L BANK OF Belg., Belgian PRIME NEwS 4 (2011), available at http://www nbb.be/doc/ts/publications/ bpnews/bpn51.pdf (report by Belgian Debt Agency \& National Bank of Belgium). In Ireland, the Central Bank now exercises the powers previously assigned to the Financial Regulator. See Minister of Finance Commences the Central Bank Reform Act 2010, DePARTMENT OF FinANCE, (Sept. 29, 2010), $\mathrm{http}: / / \mathrm{www}$ finance.gov.ie/viewdoc.asp?DocID=6517.

174. In September 2008, Belgium lost its largest financial institution, Fortis, after the bank encountered liquidity problems and stock prices dropped drastically. See Nelson D. Schwartz, Netherlands Takes Over Fortis's Dutch Operations, N.Y. TIMES, Oct. 4, 2008, at C5.

175. See supra Figure 1.

176. The ACP was created by Loi 2010-76 du 21 janvier 2010 [Law 2010-76 of Jan. 21, 2010], Journal OFFICIEL DE LA RÉPUBliQue FranÇAISE [J.O.] [OFFICIAL GAZETTE OF FranCE], Jan. 22, 2010, p. 27, available at http://legifrance.gouv fr/affichTexte.do?cidTexte=JORFTEXT0000 21719945\&fastPos=1\&fastReqId=281956259\&categorieLien=cid\&oldAction=rechTexte. This ordinance amended the Code Monétaire et Financier [Monetary and Financial Code] art. L613-3 (Fr.), available at http://www.legifrance.gouv fr/affichCodeArticle.do;jsessionid=4084C4E6A17D68B7 
powers into a variety of other administrative agencies. ${ }^{177}$ However, the United States abandoned a more ambitious plan that involved the merger of the SEC with the CFTC. ${ }^{178}$ These consolidation moves, although substantial in their own right, are far less ambitious than what critics would have desired.

Not only did countries mostly stay away from consolidating regulatory authority into single entities, but some countries with consolidated regulators even broke them apart. The most prominent example of this, and perhaps the most dramatic change in agency architecture in postcrisis reforms, was the United Kingdom's elimination of the Financial Services Authority (FSA), which regulated banking, securities, insurance, and mutual funds. Long heralded as the prime example of a consolidated regulator for the whole financial sector, the FSA model had inspired voluminous academic commentary and, arguably, reforms in other jurisdictions. ${ }^{179}$ Despite the FSA's wide powers, the Bank of England had remained the lender of last resort and the ultimate systemic regulator. After the collapse of Northern Rock, this division of authority was deemed unworkable. Consequently, reformers have decided to split the FSA into smaller administrative bodies, one of which, the Prudential Regulatory Authority (PRA), will be responsible for the prudential regulation of United Kingdom banks. The PRA will operate under the supervision of the Bank of England. ${ }^{180}$

Rather than breaking up or consolidating existing regulators, many jurisdictions created new ones. These new entities cater to a variety of regulatory needs. Some are designed to address crisis-related problems or to

6A3DE2288989877F.tpdjo14v_3?idArticle=LEGIARTI000006659592\&cidTexte=LEGITEXT00000 6072026\&dateTexte $=20080505$ (as it stood in April 2007). See Appendix I. For a discussion of the new regulator, see The ACP: An Overview, AUTORITÉ DE CONTRÔLE PRUDENTIEL, BANQUE DE FRANCE (2010), http://bdfbs-ws01 heb3 fr.colt net/acp/presentation-de-1-acp/201012-ACP-Overview. pdf.

177. See 12 U.S.C. § 5412 (2006); Donelson \& Zaring, supra note 27, at 1780.

178. See Kevin Drawbaugh \& Corbett Daly, Factbox: Some Financial Reforms Missing from U.S. Legislation, REUTERS (July 1, 2010, 3:01 PM), http://uk reuters.com/article/2010/07/01/usfinancial-regulation-missing-idUKTRE65T6UZ20100701.

179. See Howell E. Jackson, An American Perspective on the UK Financial Services Authority: Politics, Goals, and Regulatory Intensity, in REGULATORY REFORMS IN THE AGE OF FinANCIAL CONSOLIDATION: THE EMERGING MARKET ECONOMY AND ADVANCED COUNTRIES 39 (Lee-Jay Cho \& Joon-Kyung Kim eds., 2006); Karel Lannoo, Challenges to the Structure of Financial Supervision in the EU, in 12 BANK FRAGILITY AND REGULATION: EVIDENCE FROM DIFFERENT COUNTRIES 121 (George G. Kaufman ed., 2000); Rosa M. Lastra, The Governance Structure for Financial Regulation and Supervision in Europe 10 COLUM. J. EUR. L. 49 (2003).

180. The U.K. government initiated a long consultation process regarding the plan to break up the FSA on July 26, 2010, which resulted in extensive responses and effectively led to a second consultation cycle. See HM TREASURY, A NEW APPROACH to FinANCIAL REGULATION: BUILDING A STRONGER FINANCIAL SYSTEM (2011), available at http://www hm-treasury.gov.uk/d/consult newfinancial_regulation170211.pdf. As of publication, the legislative procedure for the creation of the PRA has not yet been completed. In outlining U.K. law, this Article takes into account reforms in powers as introduced by the Banking Act of 2009, but notes the intention to transfer some of the powers assigned to the previous independent regulator, the FSA, to a new independent regulator, the PRA. This is broadly in line with the PRA framework as currently proposed. 
facilitate government intervention in failing financial institutions, such as the Fund for Orderly Bank Restructuring in Spain, ${ }^{181}$ and the Financial Stability Company in Denmark. ${ }^{182}$ Others are created to assist with systemic supervision, like the Financial Stability Oversight Council (FSOC) in the United States. ${ }^{183}$

The consolidation of existing regulators, and the creation of new ones, did not strengthen the position of independent bureaucrats but often became the vehicle through which politicians reinforced their own roles. Less constrained by institutional history, politicians found new channels of influence over banking supervision through these redesigned bodies. Typically, politicians now have a greater say over the composition and decision making of newly minted agencies compared to these agencies' predecessors. For example, the French Ministry of Finance now appoints the majority of the ACP's board members, ${ }^{184}$ whereas it appointed only six out of twelve members in the ACP's main predecessor, the Credit Institutions and Investment Firms Committee (CECEI). ${ }^{185}$ Spain and Denmark placed their new emergency assistance bodies under the control of the finance ministry. ${ }^{186}$ German legislators reformed BaFin from an agency run by a single official, its chairman, to one led by a fivemember board, ${ }^{187}$ with the federal government appointing the remaining four members. ${ }^{188}$ Thus, the shake-ups in countries' regulatory architecture often ended up benefitting politicians.

That politicians now play a more central role in banking regulation is evident in the three elements of postcrisis reforms described above: politicians' direct involvement in decisions against specific actors, their authority in both emergency and nonemergency situations, and their greater ability to shape the actions and choices of new regulators. In performing these functions, politicians will interact with preexisting independent agencies, which remain a crucial depository of regulatory expertise. As the next Part shows, reformers around the world have decided to govern this interaction through institutional

181. See Law on Bank Restructuring, art. 7 (B.O.E. 2009, 155) (Spain).

182. See Financial Stability Act of September 15, 2009 (commonly referred to as "Bank Package 1") (Den.) available at https://www retsinformation.dk/Forms/R0710.aspx?id=126347.

183. See infra Part V.A.

184. Code Monétaire et Financier [Monetary and Financial Code] art. L613-3 (Fr.), available at http://www.legifrance.gouv fr/affichCode.do;jsessionid=F2585441D623AC9A46A4AE9B21F4598 A.tpdjo14v_3?idSectionTA=LEGISCTA000006170665\&cidTexte $=$ LEGITEXT000006072026\&date Texte $=20070121$ (as it stood in April 2007).

185. Id. art. L612-5, available at http://www.legifrance.gouv fr/affichCode.do;jsessionid= F2585441D623AC9A46A4AE9B21F4598A.tpdjo14v_3?idSectionTA=LEGISCTA000021724252\&c idTexte $=$ LEGITEXT000006072026\&dateTexte $=20101201$ (as it stood in December 2010).

186. See Appendix I.

187. See Jan Wagner, BaFin President to Lose Power in Leadership Revamp, INVESTMENT \& PENSIONS EUR, Sept. 20, 2007, available at http://www.ipe.com/news/bafin-president-to-lose-powerin-leadership-revamp_25413.php\#.UBxUZzFrMcg.

188. See BAFin, ARTicles of ASSOCIATION of the Federal Financial SuPERvisory AUTHORITY pt. I $\S 3(1)$, available at http://www.bafin.de/SharedDocs/Aufsichtsrecht/EN/Satzung/ satzung_bafin_eng html. 
arrangements with clear rules that often designate politicians as the ultimate decision makers.

$\mathrm{V}$.

\section{A NeW INSTITUTIONAL DESIGN FOR BANKING SUPERVISION IN THE UNITED STATES AND ABROAD}

This Article argues that, besides enumerating specific powers for politicians, postcrisis reforms around the world recalibrate politicians' and agencies' roles in banking supervision more generally. Under the postcrisis framework, regulatory officials collect information and present assessments to politicians, and broad statutory language grants politicians with wide discretion to make the final decisions. Indeed, postcrisis reforms do not deny to independent regulators the role of the primary expert in financial markets or the watchdog who best follows market developments. But reforms question the basic assumption underlying the old model of delegation to expert agencies: that if a regulator collects and assesses all necessary information, it will be able to make the right choice. As discussed below, for this final choice, reformers now turn to politicians and grant them wide latitude to reach a decision.

The new institutional arrangements take the form of councils of regulators. Although the councils comprise the heads of diverse administrative agencies, such as central bankers, securities commissioners, and deposit insurers, they operate under the leadership of a politician or a political appointee, typically the treasury secretary or finance minister. Decision making in these councils often entails supermajority requirements and veto rights that cement politicians' primary role.

To illustrate the new arrangements between independent agencies and politicians, this Part begins by examining in detail the U.S. reforms. Not only was the United States at the epicenter of the crisis but it was also an avid proponent of the agency-independence paradigm. ${ }^{189}$ Thus, the introduction of political influence channels on banking supervision in the United States is of great importance to the global debate on agency independence and political control. The Dodd-Frank Act established two regulatory councils responsible for systemic risk oversight: the Financial Stability Oversight Council (FSOC) ${ }^{190}$ whose main powers concern the prudential supervision of nonbank financial institutions, and the Orderly Liquidation Authority (OLA), ${ }^{191}$ which convenes once a financial emergency arises and covers a much broader range of institutions.

As the final Section of this Part shows, ${ }^{192}$ the new institutional arrangement-with independent agencies providing technocratic support and

189. See supra Part I.

190. See infra Part V.A.

191. See infra Part V.B.

192. See infra Part V.C. 
expert recommendations and politicians acting as the ultimate decision makers - is not unique to the U.S. regime. In one form or another, the same allocation of authority permeates reforms in most other jurisdictions that revamped their regulatory structures after 2008 .

\section{A. The U.S. Financial Stability Oversight Council}

The FSOC's main function is to facilitate information sharing and coordination of regulatory policies among its members. ${ }^{193}$ In addition to the Treasury Secretary as chair, the FSOC includes the heads of nine key financial regulators, including the Federal Reserve, the SEC, the FDIC, and the CFTC. ${ }^{194}$ State regulators are also represented in the FSOC as nonvoting members. ${ }^{195}$ Out of the FSOC's ten voting members, six are independent regulators. The FSOC holds regular meetings throughout the year (typically monthly) to discuss developments in financial markets and decide whether to undertake regulatory initiatives. $^{196}$

By far, the FSOC's most important substantive function consists in its power to decide whether to subject a nonbank financial company to prudential supervision by the Federal Reserve. ${ }^{197}$ This power manifests a fundamental pillar of the Dodd-Frank Act architecture-it allows U.S. regulators to expand their reach over financial companies ${ }^{198}$ that are not otherwise subject to comprehensive prudential supervision but are potentially important for U.S. financial stability. Nonbank financial companies - like Bear Stearns, AIG, and Lehman Brothers - were among the household names that collapsed during the 2007-08 crisis. With the FSOC's new power, U.S. regulators will have a better view of these companies' financial condition on an ongoing basis and may

193. 12 U.S.C. $\$ 5322(a)(2)(E)(2006)$.

194. The remaining voting members of the FSOC are the Comptroller of the Currency, the Director of the Consumer Financial Protection Bureau, the Director of the Federal Housing Finance Agency, the Chairman of the National Credit Union Administration Board, and a member appointed by the President with expertise in insurance. Id. § 5321(b)(1).

195. The nonvoting members of the FSOC include a state insurance commissioner, a state banking supervisor, and a state securities commissioner, along with the director of the newly established Office of Financial Research. The Act requires the state regulators in each aforementioned sector to designate one sector representative to the FSOC. Id. § 5321(b)(2).

196. Fin. Stability Oversight COUNCIL, 2011 ANNUAL REPORT (2011), available at http://www.treasury.gov/initiatives/fsoc/studies-reports/Pages/2011-Annual-Report.aspx.

197. 12 U.S.C. $\S 5323(a)(1)$ (2006). The FSOC has the same authority for financial-market utilities, i.e., institutions that constitute the infrastructure of financial markets, such as stock exchanges. Id. $\S 5463(\mathrm{a})(1)$.

198. To define financial company as a company primarily engaged in financial activities, the Dodd-Frank Act (partially codified at 12 U.S.C. § 5311(a)(6)) refers to the Bank Holding Company Act of 1956, under which the Federal Reserve determines which activities are financial in nature. $I d$. $\S$ 1843(k)(2)(A). The Federal Reserve must notify the Treasury Department of its intention and the Treasury Department may object. Id. $\S 1843(\mathrm{k})(2)(\mathrm{B})$. Similarly, the Treasury Department may recommend to the Federal Reserve which activities are financial in nature. So far, the Federal Reserve has followed a wide definition of financial activities. 
require them to limit their risk exposure before government financial assistance becomes necessary.

In this important determination, the Treasury Secretary's role is pivotal. In essence, the Dodd-Frank Act grants the Treasury Department a veto right, as it requires both a two-thirds majority among the FSOC's voting members and the consent of the Treasury Secretary. ${ }^{199}$ The Act also provides for the possibility of emergency action, again with the consent of the Treasury Secretary. ${ }^{200}$ Moreover, as FSOC chair, the Treasury Secretary manages many aspects of the procedure vis-à-vis the nonbank financial company. ${ }^{201}$ The FSOC's determination is subject to judicial review, but only under an "arbitrary and capricious" standard, which leaves substantial leeway to the government. ${ }^{202}$ In sum, in determining whether to extend prudential supervision over a company not otherwise subject to this regime, the Treasury Secretary is the leading decision maker.

\section{B. The U.S. Orderly Liquidation Authority}

The Dodd-Frank Act introduces a new process for the resolution of systemically important financial companies that are at risk of default-the Orderly Liquidation Authority (OLA). ${ }^{203}$ This Section argues that the OLA embodies a new balance between agencies' technical expertise and politicians' increased accountability: it affords the Treasury Secretary a decisive role in launching and shaping a government intervention and retains independent agencies as skilled collaborators and effective enforcers. Under the OLA, the Treasury Secretary has two key powers. First, the Treasury Secretary's consent is necessary to initiate the liquidation process, along with a positive recommendation by the FDIC and the Federal Reserve. ${ }^{204}$ Second, during the liquidation process, the Treasury Secretary alone has the power to make another key decision: how much financial support to extend to the FDICmanaged institution. ${ }^{205}$ The paragraphs that follow provide a detailed analysis of the powers held by the Treasury Secretary, the FDIC, and other regulators in the context of the liquidation process.

\section{Scope of Orderly Liquidation Authority}

Apart from retail banks and insured deposit institutions, ${ }^{206}$ all other U.S. financial institutions whose failure could endanger financial stability are

199. Id. § 5323(a)(1).

200. Id. § 5323(f).

201. Id. §5323(e)(2).

202. Id. $\S 5323(\mathrm{~h})$.

203. Id. §5384(a).

204. Id. $\S 5383(\mathrm{~b})$.

205. Id. § 5390(n)(5)(A)-(C).

206. The FDIA defines an insured depository institution as any bank or savings association whose deposits are insured by the FDIC pursuant to the FDIA. Id. $\S 1813(\mathrm{c})(2)$. 
subject to the Dodd-Frank Act's OLA. More specifically, Dodd-Frank overrides the Bankruptcy Code and other specialized provisions that would otherwise apply to bank holding companies and nonbank financial companies supervised by the Federal Reserve pursuant to FSOC determination. These companies along with their subsidiaries are now subject to the Act's OLA. ${ }^{207}$ Dodd-Frank also extends its OLA over broker-dealers and provides for the participation of the Securities Investor Protection Corporation (SIPC), a federally mandated fund that helps restore securities and cash to investors when a broker defaults. ${ }^{208}$ For insurance companies, Dodd-Frank introduces more limited changes. Because insurance companies are state-regulated, the Act does not change states' insolvency regimes but establishes a mechanism that allows the federal government to trigger the insolvency process at the state level. ${ }^{209}$

\section{Triggering Orderly Liquidation}

To illustrate the pervasiveness of politicians' new role in OLA, a brief comparison with the regime for liquidating deposit-taking institutions is helpful. The FDIC, an independent agency, can order a deposit-taking institution into receivership on its own, without input from either the Treasury or the Federal Reserve. ${ }^{210}$ The FDIC is generally required to minimize the use of insurance funds when closing down a failed institution. ${ }^{211}$ However, if extending credit to the failed institution's counterparties is necessary to avert a systemic collapse, the FDIC can sidestep this requirement by getting approval from the Federal Reserve and the Treasury. ${ }^{212}$ In sum, the FDIC can start, run, and close the receivership with no input from the Treasury or other political body. In contrast, the Dodd-Frank Act does not allow independent agencies to start any liquidation process at their own initiative. Instead, the OLA requires combined action by three government bodies: the Treasury, the Federal Reserve, and the FDIC or other sectoral regulators. In this collaborative process, the Treasury takes the leading role and has significant veto rights.

It is the Treasury, and not the FDIC, that begins the liquidation process by assessing the financial condition of the company ${ }^{213}$ and the risk its collapse

207. Id. $\S \S 5381(\mathrm{a})(11), 5383(\mathrm{a})$.

208. Id. $\S 5385(\mathrm{a})(1)$. The Act directs the Treasury Secretary to appoint the FDIC as receiver, and the SIPC as trustee. Id. $\S \S 5382(\mathrm{a})(1)(\mathrm{A})(\mathrm{i}), 5385(\mathrm{a})(1)$. As a receiver, the FDIC can decide to transfer assets of the covered broker-dealer to a bridge financial company. Id. § 5390(a)(1). After the transfer, the FDIC administers the bridge company while the SIPC handles the liquidation of any assets still held by the failed broker-dealer. $I d$. $\S 5385(\mathrm{~b})(1)$.

209. Id. $\S 5383(\mathrm{e})(1)$. Once the Treasury Secretary determines that the company's failure may endanger financial stability, it falls upon state regulators to initiate the insolvency process by filing the necessary action in state court. $I d$. $\S 5383(\mathrm{e})(3)$. However, if state regulators fail to file this action, the FDIC can take their place and file the action itself. Id.

210. Id. $\S 1818(\mathrm{a})(2)(\mathrm{A})$.

211. Id. § 1823(c)(4).

212. Id. $\S 1823(\mathrm{c})(4)(\mathrm{G})$.

213. Id. §5383(b)(1). 
poses to the U.S. financial system. ${ }^{214}$ To determine whether a company is "in default or in danger of default," 215 the Treasury Secretary examines the company's assets and obligations, assesses the size of any losses, and considers whether the company's liabilities are likely to exceed its assets. ${ }^{216}$ This determination can hardly be clear-cut, as the value of a financial asset depends on many volatile factors, including the risk of counterparty default, the market conditions at the time of determination or sale, and the liquidity needs of the financial company. Neither does the law provide any specific guidance as to what constitutes a risk to the nation's financial stability and how that risk could counterbalance any adverse impact to the company's constituents.

Before moving ahead, the Treasury must ensure that "no viable private sector alternative is available to prevent the default of the financial company." ${ }^{217}$ Thus, the Treasury must engage with private companies in an effort to put together a merger or an acquisition that would allow the failed company's business to continue. Again, Dodd-Frank leaves it to the Treasury Department to determine whether any private sector proposals are indeed viable.

\section{Procedure for Initiating Orderly Liquidation}

The Dodd-Frank Act requires the Treasury Department to request a written recommendation for action from the Board of Governors of the Federal Reserve and the FDIC. ${ }^{218}$ Alternatively, either of these two independent regulators can take the initiative to provide the recommendation to the Treasury Department even with no prior request. For both regulators, a positive recommendation requires a two-thirds majority vote from the board. ${ }^{219}$ The independent agencies' positive recommendations are not binding for the Treasury Department. Instead, the Treasury Secretary reviews the recommendations and determines, in consultation with the President, whether the circumstances warrant an orderly liquidation of the distressed financial company. Thus, the Treasury Department essentially holds a veto right over the liquidation process.

If the administration decides to go ahead, the Treasury Secretary issues a formal determination regarding the risks facing the company and appoints the FDIC — or the SIPC, in the case of broker-dealer—as receiver. ${ }^{220}$ At this point, the company's board has a choice: it can either consent to the initiation of orderly liquidation, which would speed up the process but likely result in

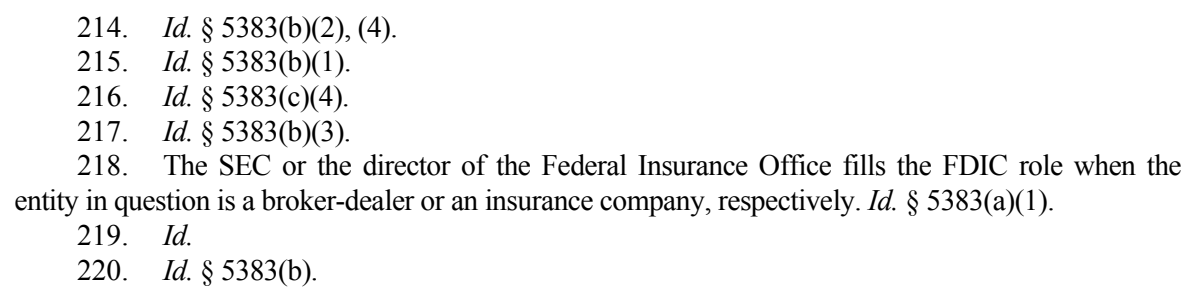


wiping out current shareholders, or it can object to the Treasury Department's determination. This is an important node in the Dodd-Frank arrangement: it places the Treasury Secretary in charge of direct communications between the government and the financial company. If the financial company objects, the Treasury Department can file a petition with the U.S. District Court for the District of Columbia, ${ }^{221}$ which has twenty-four hours to decide whether the Treasury Department's determination is arbitrary and capricious. ${ }^{222}$ The Treasury Department and the financial company have an additional thirty days to bring an appeal against the district court's ruling at the D.C. Circuit, and then another thirty days to appeal to the Supreme Court. ${ }^{223}$ Thus, the Act envisages a swift appeals process and establishes a standard of review that is particularly deferential to the Treasury Department.

\section{Receivership}

As receiver, the FDIC acquires far-reaching powers over the liquidation process. It becomes a successor of all rights, titles, powers, and privileges of the company and its assets. ${ }^{24}$ It supplants the company's board and conducts all aspects of the company's regular business. ${ }^{225}$ Moreover, the FDIC can liquidate all of the company's assets and wind up its affairs, ${ }^{226}$ lead it into a merger with another company, ${ }^{227}$ or transfer its core assets and liabilities into a separate newly formed company, typically known as a "good bank," that may itself be sold or merged. ${ }^{228}$ In an effort to ensure that U.S. taxpayers will not be on the hook for debts incurred by a failed company, Dodd-Frank prohibits the FDIC from becoming a shareholder of a failed company or its subsidiaries. ${ }^{229}$

Yet when the FDIC acts as a receiver under Dodd-Frank's OLA, it lacks an important tool available to the agency when it liquidates deposit-taking institutions. When liquidating deposit-taking institutions, the FDIC can tap into the funds for insured deposits in order to prevent a bank run. ${ }^{230}$ Under DoddFrank's OLA, the FDIC has no such power and must rely on proceeds from the liquidation of assets held by the company, which are likely to be insufficient for a company in trouble. Dodd-Frank provides the FDIC with only one alternative to asset liquidation: ask the Treasury Department for financial support through taxpayer funds.

221. Id. § 5382(a)(1)(A)(i).

222. Id. $\S 5382(\mathrm{a})(1)(\mathrm{A})(\mathrm{iv})-(\mathrm{v})$.

223. Id. $\S 5382(\mathrm{a})(2)(\mathrm{A})(\mathrm{i}),(\mathrm{a})(2)(\mathrm{B})(\mathrm{i})$.

224. Id. §5390(a)(1)(A)(i).

225. Id. $\$ 5390(\mathrm{a})(1)(\mathrm{B})(\mathrm{i})$.

226. Id. §5390(a)(1)(D).

227. Id. $\S 5390(1)(\mathrm{G})$.

228. Id. § $1821(\mathrm{~d})(2)(\mathrm{G})$.

229. Id. §5386(6).

230. The FDIC collects premiums from insured institutions into an FDIC-managed fund established under the terms of Federal Deposit Insurance Reform Act of 2005, Pub. L. No. 109-171, 120 Stat. 9 (2006). 


\section{Funding for the Intervention}

The use of taxpayer funds for a bailout is likely to be controversial. It was, after all, the repeated bailouts of financial giants like AIG and Citigroup that angered the American public and prompted Congress to redesign the architecture of financial supervision through the Dodd-Frank Act. The language of the Act expresses the public's distrust of bailouts by stating: "No taxpayer funds shall be used to prevent the liquidation of any financial company under this subchapter,"231 and "Taxpayers shall bear no losses from the exercise of any authority under this subchapter." 232

In practice, such a complete denial of financial support may not be possible or even advisable. With the appointment of a receiver, any credibility left to the financial company would evaporate quickly. Clients may seek to withdraw funds, counterparties may find themselves in dire straits, and talented employees may abandon ship quickly. Instead, financial support from the government may help smooth out these effects over time, allowing the FDIC to liquidate assets at higher prices and alleviate market disruption. To address this need, Dodd-Frank puts in place a mechanism whereby the government provides financial support and recoups any losses through assessments to the financial industry after the liquidation is finalized. ${ }^{233}$ This mechanism reflects the allocation of powers between institutional players throughout the OLA: the Treasury Department holds the key decision-making power-in this case, how much money to provide - whereas the FDIC carries out the necessary tasks on the ground.

Under Dodd-Frank's OLA mechanism, the Treasury Department provides funds to the FDIC for the continuing operation of the financial company. The Act authorizes the Treasury Department to raise the funds necessary to support the FDIC-managed financial company by issuing debt securities to the public, thus expanding the federal budget. These debt securities are obligations of the U.S. government because the Act is clear that the Treasury Department's obligation to public debt holders is independent of whether the financial company's assets will suffice to repay the Treasury Department. ${ }^{234}$

Apart from raising funds, the Treasury Department also decides whether to extend funds to the FDIC, how much to extend, and what interest rate to

231. 12 U.S.C. $\$ 5394(a)$ (2006).

232. Id. § 5394(c).

233. Funds drawn down by the FDIC must be repaid to the Treasury Department within five years. If the financial company's postliquidation assets do not suffice to pay back the Treasury Department, the FDIC imposes assessments on the company's counterparties that benefitted from discretionary government support up to the amount of their gain, and then to major financial institutions more generally. Id. § 5390(o).

234. Id. §5390(n)(5)(E). 
charge. ${ }^{235}$ Before the FDIC can draw down any funds for the company, it must develop an orderly liquidation plan that the Treasury Department accepts. ${ }^{236}$ In drafting the liquidation plan, the Dodd-Frank Act requires the FDIC and the Treasury Department to consult two congressional committees. ${ }^{237}$ Although these consultations do not amount to a consent requirement, they directly involve Congress with on-the-ground implementation details, which is an unusual role for Congress to play in financial regulation. To keep true to its "no bailouts" promise, the Act introduces some constraints on the Treasury Department's funding powers and allows it to recoup losses by transferring the burden to the financial industry. Thus, the Act sets upper limits on to the amount of funds that the Treasury Department can extend: no more than 90 percent of the fair value of each financial company's consolidated assets in total, and no more than 10 percent of that value within the first thirty days. ${ }^{238}$

\section{Reformers Abroad Provide Politicians with Wide Discretion in the Context of Common Deliberation and Codecision Procedures}

The United States was not alone in honing a new institutional balance between technocrats and politicians in banking. Most jurisdictions envisioned expert bureaucrats in the role of market monitors that collect information and formulate suggestions, but entrusted political appointees with wide latitude to make key decisions. In most jurisdictions, reformers introduced few substantive constraints on the exercise of politicians' new powers, which are at the center of the jurisdictions' new institutional designs. To illustrate these claims, this Section provides examples of politicians' increased powers from reforms in important jurisdictions besides the United States. For greater comparability, these examples examine a single power granted to political appointees in various countries: the decision to intervene and provide financing to an at-risk financial institution. This power lies at the heart of postcrisis reforms. While most jurisdictions combined input from independent regulators and politicians by granting them veto powers in institutional arrangements comparable to the United States' OLA or FSOC, other countries chose different institutional mechanisms.

\section{United Kingdom}

The Banking Act of 2009 introduced a new special resolution regime for banking institutions, which provides extensive new powers to both independent regulators and Her Majesty's (HM) Treasury. Exercise of these new powers is

235. Id. § 5390(n)(5)(A)-(C). The FDIC may sell debt obligations to the Treasury Department to obtain the funds, but the Treasury Department decides whether to purchase these debt obligations. Id. $\S 5390(\mathrm{n})(5)(\mathrm{A})-(\mathrm{B})$.

236. Id. §5390(n)(9)(A).

237. Id. § 5390(n)(9)(B)(ii).

238. Id. $\S 5390(\mathrm{n})(6)$. 
typically subject to codecision mechanisms, which effectively require agreement among all authorities involved: the Bank of England, the newly established Prudential Regulatory Authority, and HM Treasury. While one authority often takes the lead - either HM Treasury or one of the independent agencies - final exercise of the power typically requires prior consultation with, and often the express consent of, the other regulatory bodies involved. One such example is the Bank of England's power to effect the sale of a failing financial institution to either a bridge bank specifically set up for this purpose or to a private sector purchaser, if available. ${ }^{239}$ In order to exercise this power, the Bank of England must obtain the consent of the Treasury on two points. First, it must establish that the Treasury does not plan to exercise its own powers. ${ }^{240}$ Second, the Bank must obtain the Treasury's recommendation that such a sale is necessary to protect the public interest. ${ }^{241}$ An example where the Treasury takes the lead is the decision to nationalize a failing institution by having its stock acquired by the state. Before ordering a bank to pass into public ownership, HM treasury must consult with the Bank of England and the Prudential Regulatory Authority and satisfy itself that the action is necessary to resolve a serious threat to the stability of the financial system and to protect the public interest. ${ }^{242}$

While postcrisis U.K. laws require independent regulators to obtain the consent of HM Treasury in key moments, they typically provide no specific conditions or guidance that would limit HM Treasury's discretion. ${ }^{243}$ In some cases, typically when HM Treasury action will be at the center of the government's intervention, the law requires HM Treasury to justify its action; but the grounds for justification are typically ambiguous and vague, seeking to protect Treasury discretion rather than constrain it. For instance, as illustrated by the above example concerning HM Treasury's decision to nationalize a failing institution, the Treasury must be satisfied that its action "is necessary to resolve or reduce a serious threat to the stability of the financial systems of the United Kingdom" and "to protect the public interest"; 244 however, the law does not provide any further guidance as to what might constitute a serious threat to the financial system.

\section{Germany}

In Germany, the Bank Restructuring Act of 2010 significantly expanded the powers of regulators to intervene in a financial institution that faces

239. Banking Act, 2009 , c. $1, \S 8$ (U.K.).

240. Id. $\$ 7$.

241. Id. $\S 8$.

242. Id. $\S 9$.

243. For example, sections 7 and 8 of the Banking Act of 2009 require the Bank of England to consult with the Treasury prior to exercising its powers; the law provides no specific considerations for the Treasury's consultation. See id. $\S \S 7-8$.

244. See id. $\S 9$. 
collapse. ${ }^{245}$ To authorize this intervention, German law establishes a procedure that requires the cooperation of four authorities: BaFin (the independent agency generally responsible for the supervision of financial markets), the Bundesbank (Germany's central bank), the Federal Agency for Financial Market Stabilisation (FMSA) (a newly established independent agency that provides funding obtained through levies on financial institutions), and the federal government. BaFin plays a central role, as it has the authority to transfer the failing institution's assets to a bridge bank set up by the state or to a private purchaser, if available. ${ }^{246}$ To issue this order, it must consult with Germany's central bank to assess the systemic risks posed. However, if the operation requires any financial assistance, BaFin must obtain the consent of the so-called "Steering Committee," 247 which consists of representatives of the Chancellor, the Minister of Finance, the Minister of Justice, the Minister of Economics and Technology, and a representative of the German states. ${ }^{248}$ In other words, any grant of bailout funds requires approval from the central government, even though the funds originate, at least initially, from levies on financial institutions.

To provide their consent and thereby authorize BaFin's intervention, the ministers must determine the extent of systemic risk posed by the institution's collapse on German markets. ${ }^{249}$ The law defines systemic risk as a situation where the failure of one institution has a significantly negative impact on other financial sector enterprises, on the financial markets, or on the general confidence of depositors and other market participants in the proper functioning of the financial system. ${ }^{250}$ The law provides certain examples of systemic risk, but it makes clear that these are not exhaustive. ${ }^{251}$ Thus, German ministers have wide discretion in determining whether to intervene in the financial system.

\section{Spain}

Even before the 2008 financial crisis, Spanish law allocated the responsibility of supervising Spanish banks to the Bank of Spain, but required it to engage in codecisions with the Ministry of Finance (currently the Ministry of Economy and Competitiveness) with respect to certain key actions. For

245. The Bank Restructuring Act of 2010 also introduced two procedures that allow a financial institution facing collapse to voluntarily ask the permission of BaFin, the German independent regulator, to implement a reorganization plan. Bankenrestrukturierungsgesetz [Bank Restructuring Act of 2010], Dec. 14, 2010, BGBL. I §§ 20-21 (Ger.).

246. Id. $\S 48$.

247. Finanzmarktstabilisierungsgesetz [FMStG] [Financial Market Stabilization Act], Oct. 17, 2008, BGBL. I $\$ 7$ (Ger.).

248. See Structure of the FMSA, BUNDESANSTALT FÜR FinANZMARKTSTABILISIERUNG, http://www fmsa.de/en/fmsa/structure/ (last visited Jan. 30, 2013).

249. Bankenrestrukturierungsgesetz [Bank Restructuring Act of 2010], Dec. 14, 2010, BGBL. I $\S 48 \mathrm{~b}(2)$ (Ger.).

250. Id.

251. Id. 
example, to have a new bank approved, the Bank of Spain must submit a proposal to the minister and get her approval. ${ }^{252}$ The Bank of Spain actions on prudential supervision are subject to appeal before the Ministry of Finance. ${ }^{253}$ Moreover, the Bank of Spain needs to obtain the Ministry of Finance's authorization before moving ahead with emergency measures, such as temporarily lowering capital adequacy requirements for an at-risk institution. ${ }^{254}$ Apart from the codecision powers described above, the Spanish government had long-standing powers to independently seize a failing financial institution upon the proposal of the Ministry of Finance, if it determined that the institution could not provide sufficient assurance to guarantee the payment of its obligations against its creditors. ${ }^{255}$

When a 2009 law created the Fund for Orderly Bank Restructuring (FROB) to address the failures of Spanish banks resulting from the crisis, ${ }^{256}$ it conditioned any intervention on the consent of the elected government. More specifically, Spanish banks seeking to qualify for financial assistance must submit a restructuring plan to the Bank of Spain and the Minister of Finance who has a veto right over the plan's execution. ${ }^{257}$ If the FROB believes that a requesting bank's plan is not viable, it can decide to undertake the restructuring itself, provided it secures the consent of the Ministry of Finance. ${ }^{258}$

\section{Denmark}

In Denmark, the winding-up of a distressed financial institution requires action by both the Danish Financial Services Authority (DFSA) (an independent regulator) and the Danish Ministry of Finance, albeit at different stages in the process. In short, the DFSA determines whether the financial institution is in lack of capital, and the Ministry of Finance negotiates with it directly to examine ways for restructuring outside bankruptcy. A new Danish law, which came into force in October 2010, formalized an arrangement first put in place to protect Danish banks from the effects of the financial crisis, but also introduced some changes in the regulatory structure. ${ }^{259}$ Danish financial institutions make regular contributions toward a fund, known as "Financial Stability," owned and managed exclusively by the Danish Ministry of

252. See Law Regarding the Formation of Banks, Cross-Border Activity and Other Issues Relating to the Legal Regime for Credit Institutions, art. 1 (B.O.E. 1995, 18450) (Spain). (Spain).

253. Resolution Approving the Regulation of the Bank of Spain, art. 15 (B.O.E. 2000, 6533)

254. Law Regarding Investment Rates, Equity and Information Obligations of the Financial Institutions, art. 11 (B.O.E. 1985, 9680) (Spain).

255. Law on Banking Structure of December 31, 1946, art. 57 (B.O.E. 1947, 4) (Spain).

256. Law on Bank Restructuring (B.O.E. 2009, 155) (Spain).

257. Id. art. 7.

258. Id.

259. Act on Financial Stability, No. 1003 of 10 October 2008 (Den.), as subsequently amended. 
Finance. ${ }^{260}$ Once the DFSA determines that a financial institution may be undercapitalized, it asks the institution to provide capital assurances by a certain deadline. ${ }^{261}$ If the institution fails to meet the deadline, it has a choice: it can negotiate directly with Financial Stability and hand over its business or enter into regular bankruptcy proceedings. ${ }^{262}$

\section{France}

French law provides a unique example of codecision procedures among various institutional players. Codecision in France does not take place in the context of a regulatory procedure specifically devised for certain key decisions, as in Germany or the United States. Instead, the authority for these decisions belongs to a single body: Autorite de Contrôle Prudentiel (ACP), the French banking supervisor. However, the composition of the ACP presents strong similarities to the United States' FSOC. More specifically, the ACP is a council chaired by the President of the Bank of France and includes the President of the Autorité des Marchés Financiers (AMF) (the French securities regulator), the Autorité des Normes Comptables (ANC) (the French accounting standards board), eight banking and insurance experts appointed by the government, three top judges, and two members representing the French legislature. ${ }^{263}$ Of these nineteen members, the government appoints fourteen. Moreover, the Finance Ministry's Director of the Treasury, as well as the Director of Social Security, sit in all ACP meetings and express their views. Although they cannot vote, they can ask the ACP to reconsider its actions and ask for a new vote. ${ }^{264}$ In its plenary form, the ACP board provides general regulatory directions, approves the ACP budget, and supervises lower-level councils that perform day-to-day supervisory tasks in banking and insurance. Most of the ACP's sanctioning powers, including the power to revoke a banking license (which leads to liquidation), are exercised by the Sanctions Committee, a body independent from the ACP board that consists of three top judges and three appointees of the Ministry of Finance. ${ }^{265}$ As a result, any ACP decision to liquidate a financial institution is possible only if the Ministry of Finance agrees.

260. $I d . \S 9$.

261. Id. § $16 \mathrm{f}$.

262. Id. $\S 16 \mathrm{~g}$.

263. Code Monétaire et Financier [Monetary and Financial Code] art. L612-5 (Fr.). An institutional design that combines members of many different authorities has a long history in French banking supervision. The Commission Bancaire, ACP's predecessor, also included representatives from various authorities, although not as many or as varied as ACP.

264. Id. art. L612-11.

265. Id. art L612-9. 
VI.

\section{POLITICIANS IN BANKING SUPERVISION: BENEFITS AND RISKS}

As this Article has shown, postcrisis reforms around the world provided politicians and their appointees with direct powers over the supervision of financial institutions, offering them wide discretion to make some of the most fundamental decisions in financial regulation. ${ }^{266}$ In their new role, politicians work closely with administrative agencies in an institutional setting that encourages exchange of information and collective deliberation, punctuated by agenda setting powers, supermajority voting requirements, and veto rights. ${ }^{267}$

This Part discusses the implications of the shift away from independent bureaucratic authority toward political decision making. Theories exalting the virtues of agency independence, presented in the early part of the Article, offer - by implication - rather grim predictions about politicians' performance. For a fuller portrayal of the positives and negatives of the new reforms, this Part now focuses the spotlight directly on politicians. Its task is to formulate theoretical expectations about politicians' performance as banking supervisors, drawing from widely established but general theories of political decision making. The starting point for this discussion is an argument often raised by some administrative law scholars: if elected politicians hold some sway over independent agencies, they can bring enhanced accountability and legitimacy to financial regulation and can use their executive powers to avert an economic catastrophe more effectively. While this Article does not deny the logic of majoritarianism, it does not share the enthusiasm about the motivations that could lead politicians' bailout decisions. In fact, it argues that politicians are also subject to pressures from special interest groups, the general public, and the electoral process itself, which can lead politicians astray.

\section{A. Politicians Bring Greater Accountability, Legitimacy, and Effectiveness in Financial Regulation}

\section{Accountability and Legitimacy}

According to majoritarian principles of government, policy choices that involve trade-offs between competing interests and values are the duty of elected politicians, who will use state power to improve aggregate social welfare, rather than to benefit a select few. ${ }^{268}$ Yet in the modern regulatory state, these choices often fall on the hands of administrative agencies. ${ }^{269}$ To

266. See supra Part IV.

267. See supra Part V.

268. See Anthony Downs, In Defense of Majority Voting, 69 J. POL. ECON. 192, 195 (1961).

269. For best practices on how to manage these trade-offs, see Giandomenico Majone, Strategic Issues in Risk Regulation and Risk Management, in OECD REVIEWS OF REGULATORY REFORM: RISK AND REGULATORY POLICY: IMPROVING THE GOVERNANCE OF RISK 93, 123-24 (Gregory Bounds et al. eds., 2010). 
ensure that inherently political decisions are indeed taken by accountable institutions, many scholars have called for elected politicians to exercise greater influence over agency policies. ${ }^{270}$ This approach to administrative decision making, dubbed by some scholars as the "political-control model," has prevailed in the academic literature for several decades. ${ }^{271}$

Another set of democracy-based arguments emphasizes the advantages of the electoral process not as a method to arrive at the optimal substantive solution, but as a mechanism that provides legitimacy for a decision maker's hard choices. ${ }^{272}$ According to this view, elections reassure ordinary citizens that political leaders enjoy the support of the majority. As a result of electoral accountability, politicians' choices command respect from all voters, who understand that they must comply regardless of their individual views. For all these reasons, enhancing legitimacy is particularly important when a politician's choice may prove unpopular based on its substance.

If broad trade-offs between competing values and interests define the political character of government action, ${ }^{273}$ then it is easy to see bank bailouts as inherently political moves. ${ }^{274}$ During the crisis, U.S. government bodiesincluding the Treasury Department, the Federal Reserve, and the FDIC-chose to spend trillions of dollars in order to prevent wider disruption in the financial system and to stave off an economic downturn that could prove detrimental to many ordinary citizens. ${ }^{275}$ This choice involved a transfer of money from taxpayers to failing institutions and their creditors. For theorists of democracy, this deeply political character of bank bailouts commands a democratic polity's highest safeguards of accountability and legitimacy.

From the perspective of the political-control model, postcrisis reforms put in place an institutional apparatus that ties bailout choices to voter interests. By granting politicians a say over the banking supervisory choices most likely to

270. See, e.g., Peter L. Strauss \& Cass R. Sunstein, The Role of the President and OMB in Informal Rulemaking, 38 ADMIN. L. REV. 181, 183-84 (1986); Richard J. Pierce, Jr., The Role of Constitutional and Political Theory in Administrative Law, 64 TEX. L. REV. 469, 520-25 (1985).

271. See Kathryn A. Watts, Proposing a Place for Politics in Arbitrary and Capricious Review, 119 YALE L.J. 2, 35 (2009).

272. See O'Connell, supra note 35, at 894; Lisa Schultz Bressman, Beyond Accountability: Arbitrariness and Legitimacy in the Administrative State, 78 N.Y.U. L. REV. 461, 485-91 (2003) (describing how various models of the administrative state connected accountability to the President with increased legitimacy of administrative action).

273. See Martin H. Wolfson, The Evolution of the Financial System and Possibilities for Reform, in TRANSFORMING THE U.S. FINANCIAL SYSTEM: EQUITY AND EFFICIENCY FOR THE $21 \mathrm{ST}$ CENTURY 133, 133 (Gary Dymski et al. eds., 1993) (describing the basic system of U.S. public intervention set up in the 1930s).

274. See Adam J. Levitin, In Defense of Bailouts, 99 GeO. L.J. 435, 506-07 (2011); see also Guillermo Rosas, CuRbing BaIlouts: BANK CRises and DEMOCRaTiC ACCOUNTABILITY IN COMPARATIVE PERSPECTIVE 108-12 (2009) (providing empirical support for the proposition that bailout choices are influenced by political regime type).

275. For a discussion of the transfers involved in the TARP program, see generally CONG. OVERSIGHT PANEL, supra note 78. 
involve political trade-offs - such as bailouts - reformers demarcated a channel for voter input. Thus, proponents of the political-control model hope that future bailout choices promote the well-being of society as a whole, rather than the interests of the financial industry. The increase in political accountability is a response to concerns that independent regulators had grown too close to the financial industry and, consequently, placed greater weight on an action's consequences for the industry than its impact on taxpayers. ${ }^{276}$

\section{Effectiveness}

An independent agency's powers are typically limited to the area it has been created to regulate, and its policy-making tools are tailored to that area's specific needs. ${ }^{277}$ Thus, an independent agency's flexibility in dealing with a financial institution nearing collapse is circumscribed by the limits of its delegated authority. For example, a financial regulator seeking to help a failing institution could relax accounting requirements for certain categories of asset holdings.

Compared to financial regulators, political leaders have a greater array of powers and responsibilities in modern democracies. To start, politicians have a range of policy tools that independent agencies do not have: they can mobilize the police force, access superior resources, and bargain with foreign countries. ${ }^{278}$ Scholars have emphasized the President's ability to make quick decisions, engage in swift action, and utilize versatile policy tools that can address unanticipated events. ${ }^{279}$ Moreover, politicians have extensive authority over various sectors of business activity, which allows them to strike more complicated bargains with financial firms. For example, they may relax antitrust review in order to quickly finalize a merger between financial institutions in a moment of crisis. More flexible and influential than specialized regulators, politicians may also prove more effective in addressing a systemic collapse.

\section{B. Politicians May Rely on Considerations Unconnected to the Merits of a Bailout Choice}

Scholars have long identified risks arising from politicians' continuous struggle for reelection. Concerns about the overpowering influence of majorities are widely established and have an impressive intellectual

276. See supra Part II.

277. See Judith E. Gruber, Controlling Bureaucracies: Dilemmas in Democratic GOVERNANCE 13-24 (1987) (discussing the substantive and procedural constraints that agencies face).

278. See Jonathan G.S. KopPell, The Politics OF QuASI-GOVERnMENT: Hybrid ORGANIZATIONS AND THE DYNAMICS OF BUREAUCRATIC CONTROL 37-60 (2003) (discussing the tools available to politicians and agencies).

279. See Eric A. Posner \& Adrian Vermeule, Crisis Governance in the Administrative State: 9/11 and the Financial Meltdown of 2008, 76 U. CHI. L. REV. 1613, 1638 (2009). 
pedigree. ${ }^{280}$ Fears that political leaders will succumb to an unruly and unprincipled electorate are deeply ingrained in the earliest accounts of democratic regimes. ${ }^{281}$ As a shift in the electoral landscape brings a different administration in power, government policies may change. ${ }^{282}$ These insights can help illuminate the challenges that political leadership brings to financial regulation.

After postcrisis reforms, the power to bailout a failing financial institution has become another tool in a politician's kit, to be used in the manner most likely to bring together a winning electoral coalition. In determining how to use this new power, politicians might pursue multifaceted objectives that have very little to do with the financial institution's creditworthiness or the societal implications of a systemic collapse. The paragraphs below describe how considerations arising from timing, adverse public opinion, and opportunities for side bargains could affect politicians when setting the bailout apparatus in motion. These considerations serve as illustrations rather than an exhaustive list.

\section{Timing}

Timing considerations can play a key role in a politician's decision to bail out a financial institution because of the pressures arising from the electoral cycle. ${ }^{283}$ Politicians who have just secured an electoral victory have significant political capital to spend and may be more willing to disregard opposition by constituents. Conversely, politicians who are facing an upcoming electoral battle may be more attuned to the desires of the majority. ${ }^{284}$ Political scientists have long identified that good economic conditions before an election improve an incumbent's chance of reelection. ${ }^{285}$ In anticipation of this effect, politicians

280. Tocqueville warned of the "tyranny of the majority," in which the majority prioritizes its own modest gains over the strong objections of an unfortunate few. AlEXIS DE TOCQUEVILLE, 1 DEMOCRACY IN AMERICA 290 (Henry Reeve trans., 1899).

281. Aristotle takes pains to distinguish a regime in which all citizens are called on to make decisions and form informed views after deliberation and rational reasoning from a deviant condition where political power passes to an angry mob. ARISTOTLE, THE POLITICS AND THE CONSTITUTION OF ATHENS 91, 99 (Stephen Everson ed., 1996) (contrasting democracies in which "the best citizens hold the first place" to democracies in which the majority has complete authority to "exercise a despotic rule over the better citizens").

282. Traditionally, scholars have justified delegation to independent bureaucracies as a method to reduce policy variability over time. See, e.g., Gilardi, supra note 6; Philip Keefer \& David Stasavage, The Limits of Delegation: Veto Players, Central Bank Independence, and the Credibility of Monetary Policy, 97 AM. POL. SCI. REV. 407, 407 (2003).

283. For an analogous discussion of how political cycles influence rulemaking, see generally O'Connell, supra note 35.

284. For a discussion of how political capital is earned and spent, see generally Paul S. Herrnson et al., The Impact of Presidential Campaigning for Congress on Presidential Support in the U.S. House of Representatives, 36 LEGIS. STUD. Q. 99 (2011).

285. See, e.g., Sean Carey \& Matthew J. Lebo, Election Cycles and the Economic Voter, 59 POL. ReS. Q. 543, 543 (2006); Michael B. MacKuen et al., Peasants or Bankers? The American Electorate and the U.S. Economy, 86 AM. POL. SCI. REV. 597, 597 (1992). 
tend to increase spending in hopes of stimulating the economy immediately before an election. ${ }^{286}$ On the other hand, politicians may not be willing to adopt measures that are likely to benefit the nation in the long run simply because those results are unlikely to materialize by the upcoming elections.

These observations suggest that the timing of a financial emergency in relation to elections can affect politicians' responses, regardless of the bailout's implications for the financial system. When a financial emergency hits right before an upcoming election, incumbents loath to take the blame for a collapse might be tempted to authorize bailouts at any cost. On the other hand, when an institution faces collapse shortly after an election, victorious politicians might be less concerned by systemic considerations, betting on an economic recovery down the line. In this case, politicians might be open to a gesture that affirms their ideological commitments—-for example, by punishing a failing bank.

\section{Adverse Public Opinion}

The need for politicians to exercise their bailout powers arises at moments of acute crisis - precisely when voters' trust in the financial system is likely to be at a record low. The median-voter theorem suggests that elected leaders will enact policies preferred by voters at the center of the political spectrum. ${ }^{287}$ However, as voters are uncertain about the depth of a failing institution's problems and the associated systemic implications, they cannot easily ascertain the trade-offs involved in a proposed bailout. ${ }^{288}$ Yet at the same time, voters can clearly see the failures of the financial system and consequently are likely to distrust financial institutions. ${ }^{289}$ Thus, voters might be opposed to government action in support of the financial industry, regardless of the costs and merits of government intervention. An electorate negatively predisposed against the financial industry can create hurdles for political leaders. In other

286. See generally Margarita Katsimi \& Vassilis Sarantides, Do Elections Affect the Composition of Fiscal Policy in Developed, Established Democracies?, 151 PuB. CHOICE 325 (2012); Kenneth Rogoff \& Anne Sibert, Elections and Macroeconomic Policy Cycles, 55 REV. ECON. STUD. 1 (1988). See also Robert M. Stein \& Kenneth N. Bickers, Congressional Elections and the Pork Barrel, 56 J. POL. 377 (1994).

287. See Randall G. Holcombe, The Median Voter Model in Public Choice Theory, 61 PUB. CHOICE 115, 116 (1989).

288. See, e.g., Posner \& Vermeule, supra note 279, at 1614.

289. For example, a 2009 Democracy Corps poll found that 69 percent of respondents agreed that "AIG's use of bailout money to pay out bonuses to its executives shows that we need tighter government regulation of the financial industry." $A I G$, POLLING THE NATIONS, http://poll.orspub.com/ document.php?id=quest09.out $418 \&$ type $=$ hitlist\&num $=60$ (last visited Jan. 30, 2013). According to a 2009 Marist College Poll, 80 percent of respondents would give the financial industry a C, D, or F grade for honesty and ethical conduct. Business, Ethics, POLLING THE NATIONS, http://poll.orspub. com/document.php?id=quest09.out_1425\&type=hitlist\&num=63 (last visited Jan. 30, 2013). In a 2009 Rasmussen Poll, 80 percent of respondents found that Wall Street had benefited more than the average taxpayer from the government bailout of the financial industry. Bailout, POLLING THE NATIONS, http://poll.orspub.com/document.php?id=quest09.out_748\&type=hitlist\&num=49 (last visited Jan. 30, 2013). 
words, there is a significant risk that voters, in the midst of uncertainty and widespread skepticism, might press politicians to refrain from intervening in the financial industry when intervening would be otherwise appropriate. ${ }^{290}$

Political leaders need to appeal not only to swing voters, but also to their partisan bases, which tend to have more extreme ideological positions. ${ }^{291}$ Yet while ideological polarization concerning the financial industry has grown significantly more pronounced, the far left and far right of the political spectrum nonetheless agree on one issue: staunch opposition to bank bailouts. ${ }^{292}$ On the left, the Occupy Wall Street movement has made headlines expressing discontent with the financial industry as the primary mechanism for aggregation of wealth. On the right, the Tea Party movement rallies against any government intervention in the economy, whether such intervention lets banks grow exponentially or fail spectacularly. Both positions build on the American public's long-standing disenchantment with banks and banking. ${ }^{293}$ As the electorate grows more polarized in connection with the financial industry, ${ }^{294}$ the risk that politicians must cater to voters far removed from the center also increases. As a result, politicians' eventual choices may reflect more radical tendencies in public opinion.

\section{Opportunities for Side Bargains}

The financial industry's interests in influencing politicians' bailout choices are apparent. On the one hand, greater electoral vigilance might limit politicians' room to maneuver. But on the other hand, a regime that puts politicians at the helm creates greater incentives for financial firms to strengthen their relationships with future regulators. For example, they can intensify their lobbying efforts and increase their campaign contributions. ${ }^{295}$ In

290. For example, a 2010 CBS poll found that 37 percent of voters would be less likely to support a candidate for Congress who supported a government bailout, as compared to 15 percent of voters who would be more likely to support this candidate. Financial Crisis, POLLING THE NATIONS, http://poll.orspub.com/document.php?id=quest10.out_5691\&type=hitlist\&num=8 (last visited Jan. 30, 2013).

291. For a useful review of this literature, see generally Bernard Grofman, Downs and TwoParty Convergence, 7 ANN. REV. POL. SCI. 25 (2004).

292. See Alex Cukierman, The Roles of Ideology, Institutions, Politics, and Economic Knowledge in Forecasting Macroeconomic Developments: Lessons from the Crisis, 56 CESIFO ECON. STUD. 575, 588 (2010).

293. For an early analysis of the American public's views of the banking sector, see generally Gurden Edwards, Banking and Public Opinion, 1 PUB. OPINION Q. 5 (1937).

294. See generally Atif R. Mian et al., Resolving Debt Overhang: Political Constraints in the Aftermath of Financial Crises (Nat'1 Bureau of Econ. Research, Working Paper No. 17831, 2012), available at http://www nber.org/papers/w17831.pdf?new_window=1 (discussing how polarization increases after financial crises).

295. That campaign contributions affect politicians' stance toward specific companies is a well-studied phenomenon. For more details on how particular industries channel their contributions, see generally Kevin B. Grier et al., The Determinants of Industry Political Activity, 1978-1986, 88 AM. POL. SCI. REV. 911 (1994). 
effect, politicians' greater power induces financial firms to use their resources to compete with each other for political favoritism. Thus, there are ex ante strong theoretical reasons to suggest that financial firms' influence on policy makers' decisions might increase, rather than decrease.

As financial firms struggle to improve their standing with the government, some may prove more successful than their counterparts. In 2007-08, there were widespread concerns that the decision to bail out some firms and not others resulted from close connections between prominent Wall Street banks and the government. ${ }^{296}$ Politicians are well known for rewarding their supporters and punishing their opponents, and may thus have greater discretion to treat firms differently. In contrast, bureaucracies derive their legitimacy from a culture of uniformity. ${ }^{297}$ Bureaucrats, whether public-interest-minded civil servants striving to implement technical orthodoxies or biased sheriffs fresh out of the industry's revolving door, are supposed to follow rules and procedures and to apply them uniformly to all participants in the industry. This cultural difference is particularly important with respect to questions of financial stability because differential treatment introduces unnecessary variation in the levels of risk that different institutions face.

While competition for political favoritism among firms is harmful in any industry, it becomes particularly disconcerting in the context of the financial industry. Financial institutions can offer diverse bargains and side deals to politicians, even on issues far removed from the potential implications of a financial crisis. Some politicians might be interested in reducing or expanding government debt and thus ask financial institutions to help them in this effort. Others might have a prominent policy agenda promoting specific industries or regions and thus ask financial institutions to support these constituents. In short, as politicians build diverse alliances in order to be elected to office, they might use their powers over financial institutions to further goals unrelated to the stability of the financial system and satisfy their allies. ${ }^{298}$

\section{The Long-Term Horizon of Bailout Choices}

Electoral timing, adverse public opinion, and opportunities for side bargains may introduce considerations into politicians' decision making that have little to do with the health of the financial system. While these three factors introduce distortions particularly acute in financial regulation as Part VI.B has shown, their impact is not limited to finance alone. Rather, these considerations plague government regulation of business more generally

296. See Richard W. Painter, Bailouts: An Essay on Conflicts of Interest and Ethics When Government Pays the Tab, 41 MCGEORGE L. REV. 131 (2009).

297. This point was famously made by Max Weber. Max Weber, Bureaucracy, in From MAX WEBER: ESSAYS IN SOCIOLOGY 196-244 (H.H. Gerth \& C. Wright Mills eds., 1958).

298. Politicians' wide powers over various regulatory areas also increase their effectiveness in handling a financial collapse. For a discussion of this argument, see supra Part VI.A.2. 
without dissuading supporters of majoritarianism from arguing for the value of greater democratic accountability. Yet this Article argues that finance stands apart from other business sectors because of one further complication: the interaction of these three distortive considerations with the long-term character of bailout outcomes.

At the time a bailout choice is to be made, its costs are highly contingent and thus far from clear. By design, bailout packages pledge enormous sums to shore up an ailing financial system and restore confidence in the markets. These same pledges also leave a strong mark on public consciousness, which registers bailouts as forcing taxpayers to foot the bill for bankers' misguided investments. However, the ultimate impact of a bailout on government finances may not be evident until years after the initial intervention, when the government can liquidate its holdings and safely exit then-restored institutions. In this respect, a government bailout choice is akin to the decision of an investor, who evaluates the quality of a portfolio of financial assets and predicts that these assets will yield a return at a certain point in the future. In fact, governments possess a key advantage compared to investors: they face few liquidity constraints, and thus can afford to take a long-term view as to the prospects of their investments. In other words, governments can hold onto their bailout portfolios until after the crisis abates and sell their holdings at a profit when the right opportunity emerges.

The U.S. government's bailouts during the 2007-08 crisis illustrate this dynamic. For example, the government's assistance to AIG, the insurer whose disastrous credit default swaps led it to near bankruptcy in 2008, started being gradually repaid in $2010 .^{299}$ After selling its last holdings in AIG shares in December 2012, the Treasury recorded a government profit of $\$ 22.7$ billion. ${ }^{300}$ Similarly, when the U.S. government exited Citigroup, the crisis-hit banking giant that had sold a controlling stake to the Treasury in return for bailout assistance in 2008 and 2009, the Treasury made a profit of $\$ 12$ billion. $^{301}$ According to the latest estimates, the government has recouped $\$ 455$ billion out of the $\$ 605$ billion TARP funds that it had dispersed. ${ }^{302}$ Most of the yet unrecovered funds relate to the bailout of Fannie Mae and Freddie Mac, the government-sponsored entities engaging in mortgage purchases. ${ }^{303}$ But even with regard to these two entities, the Treasury recently revamped their bailout

299. Gov't Accountability OfFice, Troubled Asset Relief Program: GOVERNMENT'S EXPOSURE TO AIG LESSENS AS EQUITY INVESTMENTS ARE SOLD 7-15 (2012).

300. Timothy Ahmann, Treasury Says Has Completed Final Sale of AIG Stock, REUTERS (Dec. 14, 2012, 11:57 AM), http://www reuters.com/article/2012/12/14/us-aig-treasury-sale-idUSBRE 8BD0W020121214.

301. David Lauder, U.S. Exits Citigroup Stake and Earns \$12 Billion Profit, REUTERS (Dec. 7, 2010, 12:22 PM), http://www reuters.com/article/2010/12/07/us-citigroup-treasury-offering-idUSTRE 6B55KP20101207.

302. Bailout Tracker, PROPUBLICA (Jan. 29, 2013), https://projects.propublica.org/bailout/.

303. Id. 
terms so that all the entities' future profits are used to repay taxpayers. ${ }^{304}$ Thus, the total costs to U.S. taxpayers arising from the 2008 and 2009 government interventions in the financial system appear significantly lower today than the government's initial exposure, and some bailout decisions have even returned profits to taxpayers.

The long-term profile of bailout choices is in tension with the short-term outlook of political considerations. In the heat of a financial crisis, a bailout choice presents the decision maker with the highest possible exposure to liability, reflecting the possibility that bailout funds will never be repaid. Amid market uncertainty, the government is asked to pay significant sums for financial assets that might seem at best overpriced, or at worst worthless. Making such payments requires a decision maker who disregards catastrophic market signs, goes against the wave of dismal valuations, and grasps the importance of systemic connections. Institutionally, this choice is better assigned to the decision maker whose future does not depend on the immediate impact of bailout decisions, but rather on the ultimate success of the program. As Part VI.B has shown, politicians are more likely to focus on immediate, short-term, and direct electoral payoffs. This is why timing considerations, adverse public opinion, and interest group pressures may affect politicians with particular force. And this is why independent agencies, with the long-term outlook of bureaucrats, are free to disregard these forces and remain patiently concentrated on the ultimate results.

\section{CONCLUSION}

In the long history of financial regulation, rare are the moments in which policy makers have stepped back to look at the financial system from a distance and revisit the foundational elements of modern economies' power engine. Modern financial regulation was premised on highly technical sophistication and attention to detail, best exemplified by the independent agency paradigm. For decades, regulators followed markets' lead and struggled to keep up with ever-more complicated financial instruments developing at an ever-increasing speed. After 2008, this Article argues, governments seized the initiative anew. The crisis revealed both how much financial industry giants depended on governments' liquidity support and, conversely, the strength of governments' interests to fight for the financial system's survival. Startled by the impact of the crisis, policy makers around the world quickly granted new decisionmaking powers in banking supervision not to independent experts but to political animals: elected leaders and their direct appointees.

304. Rachelle Younglai, U.S. Tightens Reins on Fannie Mae, Freddie Mac, REUTERS (Aug. 17, 2012, 5:17 PM), http://www reuters.com/article/2012/08/17/us-usa-housing-idUSBRE87G0EN 20120817. 
By pushing politicians into a new prominent role in banking supervision, postcrisis reformers sought to combine responsiveness to popular will with technical expertise. In doing so, they redefined the interaction between institutions - political leaders and independent bureaucrats - that previous paradigms kept as separate from each other as possible. Independent bureaucrats are still responsible for the bulk of supervisory activity: monitoring performance, collecting information, and establishing new rules. But in many key decisions, politicians cast the decisive votes. In the postcrisis financial regulatory framework, the ideals of expertise and policy stability must leave space for values such as greater accountability, legitimacy, and effectiveness.

This rebalancing of political force and technocratic composure occurs over one of the most critical decisions that modern statesmen must face: whether to intervene to support a financial system in distress. Worries that such an intervention burdens taxpayers and represents an unneeded subsidy to the financial industry fueled public concerns in 2008. But an unnecessary bailout represents only one side of a regulatory misfire. Much more disconcerting is the opposite side: a bailout that financial circumstances would warrant but that, unfortunately, the government fails to authorize. The ensuing collapse of the financial system would bring the economy to a halt, destroy the life savings of many, and drive unemployment and poverty to record highs. Under these circumstances, the government's decision to avoid a bailout could prove a true catastrophe.

Following postcrisis reforms, political leaders must make bailout decisions in the headwinds of electoral strategizing, ideological polarization, and interest group pressures. These considerations compound the uncertainties characteristic of any bailout choice, as it is hard to assess beforehand the likelihood that any single institution's failure will spread into a systemic collapse. When forming their choice, are politicians likely to weigh more heavily electoral factors or financial risks? Answering this question definitively requires waiting until the next crisis. Ex ante, however, the risk of a financial catastrophe might now hinge upon considerations that have little to do with the health of the financial system.

This Article offers a suggestion: voters must learn more about their elected leaders' positions on the banking industry. To truly respond to the public's calls for greater accountability, electoral campaigns should embrace the new position politicians occupy in financial regulation and reveal their thinking on systemic considerations. Bailouts can test a politician's limits: when the phone next rings at 3:00 a.m. in the White House, whether to bail out financial institutions might be the trillion-dollar question regulators ask the President. 


\section{APPENDIX I: INDIVIDUAL COUNTRY INDEX SCORES}

\section{Australia}

Main reform laws: The main codified piece of banking legislation in Australia is the Banking Act 1959 (Cth), available at http://www.comlaw. gov.au/Series/C2004A07357. It was continuously amended throughout the period studied in the Article, most notably by Financial Sector Legislation Amendment (Prudential Refinements and Other Measures) Act 2010 (Cth), available at http://www.comlaw.gov.au/Details/C2010A00082.

\begin{tabular}{lcc}
\hline \hline Questions & 2007 & 2010 \\
\hline 1. Does the FM have direct powers in prudential supervision? & 0 & 1 \\
2. Does the FM appoint the majority of prudential authority & 1 & 1 \\
$\quad$ members? & & \\
3. Can the FM fire prudential authority members? & 0 & 0 \\
4. Does the FM appoint the majority of supervisory authority & 1 & 1 \\
$\quad$ members? & & \\
5. Can the FM fire supervisory authority members? & 0 & 0 \\
6. Does the FM appoint the majority of deposit insurance & 0 & 1 \\
$\quad$ authority members? & & \\
7. Can the FM fire deposit insurance authority members? & 0 & 1 \\
8. Is FM consent required for key prudential authority & 0 & 0 \\
$\quad$ decisions? & & \\
9. Is FM consent required for key supervisory authority & 0 & 0 \\
$\quad$ decisions? & & \\
10. Can FM reverse the decisions of prudential supervisors? & 0 & 0 \\
11. Can FM issue rulemakings that affect prudential & 1 & 1 \\
$\quad$ supervisors' decisions? & & \\
12. Is FM consent required for resolution of a qualified & 0 & 0 \\
$\quad$ institution? & & \\
13. Is the resolution decision shielded from judicial review? & 0 & 0 \\
14. Is FM involved in the resolution process? & 0 & 1 \\
15. Is FM responsible for extending loans during the resolution? & 1 & 1 \\
\hline$\quad$ Total & 4 & 8 \\
\hline \hline
\end{tabular}

\section{Belgium}

Main reform laws: Loi modifiant la loi 2 août 2002 relative à la surveillance du secteur Financier et aux services financiers, Ainsi que la loi du 
féveier 1998 fixant organique le statute de la Banque Nationale de Belgique et portant dispositions diverses [Law amending the Law of 2 August 2002 on the supervision of the financial sector and financial services and the Law of 22 February 1998 establishing the Organic Statute of the National Bank of Belgium, and providing various provisions] of July 2, 2010, Moniteur Belge [M.B.] [Official Gazette of Belgium], Sept. 28, 2010, 59140 (Belg.).

\begin{tabular}{|c|c|c|c|}
\hline & Questions & 2007 & 2010 \\
\hline 1. & Does the FM have direct powers in prudential supervision? & 0 & 1 \\
\hline 2. & $\begin{array}{l}\text { Does the FM appoint the majority of prudential authority } \\
\text { members? }\end{array}$ & 1 & 1 \\
\hline 3. & Can the FM fire prudential authority members? & 0 & 0 \\
\hline 4. & $\begin{array}{l}\text { Does the FM appoint the majority of supervisory authority } \\
\text { members? }\end{array}$ & 1 & 1 \\
\hline 5. & Can the FM fire supervisory authority members? & 0.5 & 0 \\
\hline 6. & $\begin{array}{l}\text { Does the FM appoint the majority of deposit insurance } \\
\text { authority members? }\end{array}$ & 1 & 1 \\
\hline 7. & Can the FM fire deposit insurance authority members? & 1 & 1 \\
\hline & $\begin{array}{l}\text { Is FM consent required for key prudential authority } \\
\text { decisions? }\end{array}$ & 0 & 0 \\
\hline & $\begin{array}{l}\text { Is FM consent required for key supervisory authority } \\
\text { decisions? }\end{array}$ & 0 & 0 \\
\hline 10. & Can FM reverse the decisions of prudential supervisors? & 0 & 0 \\
\hline 11. & $\begin{array}{l}\text { Can FM issue rulemakings that affect prudential } \\
\text { supervisors' decisions? }\end{array}$ & 1 & 1 \\
\hline 12. & $\begin{array}{l}\text { Is FM consent required for resolution of a qualified } \\
\text { institution? }\end{array}$ & 0 & 1 \\
\hline 13. & Is the resolution decision shielded from judicial review? & 0 & 0 \\
\hline 14. & Is FM involved in the resolution process? & 0 & 1 \\
\hline & $\begin{array}{l}\text { Is FM responsible for extending loans during the } \\
\text { resolution? }\end{array}$ & 0 & 0 \\
\hline & Total & 5.5 & 8 \\
\hline
\end{tabular}

\section{Canada}

Main reform laws: No major reforms were introduced during the period studied in this Article. 
Questions

$2007 \quad 2010$

1. Does the FM have direct powers in prudential supervision? 11

2. Does the FM appoint the majority of prudential authority $\quad \begin{array}{ll}1 & 1\end{array}$ members?

3. Can the FM fire prudential authority members? $\quad 0.5 \quad 0.5$

4. Does the FM appoint the majority of supervisory authority $1 \quad 1$ members?

5. Can the FM fire supervisory authority members?

6. Does the FM appoint the majority of deposit insurance authority members?

7. Can the FM fire deposit insurance authority members? $\quad 0.5 \quad 0.5$

8. Is FM consent required for key prudential authority $\quad \begin{array}{lll}0 & 0\end{array}$ decisions?

9. Is FM consent required for key supervisory authority $\quad \begin{array}{lll}0 & 0\end{array}$ decisions?

10. Can FM reverse the decisions of prudential supervisors? $\quad 1 \quad 1$

11. Can FM issue rulemakings that affect prudential supervisors' decisions?

12. Is FM consent required for resolution of a qualified institution?

13. Is the resolution decision shielded from judicial review? $\quad \begin{array}{lll}0 & 0\end{array}$

14. Is FM involved in the resolution process? $\quad 0 \quad 0$

15. Is FM responsible for extending loans during the $\quad \begin{array}{lll}0 & 0\end{array}$ resolution?

\section{Denmark}

Main reform laws: Financial Stability Act of September 15, 2009 (commonly referred to as "Bank Package 1") available at https://www.rets information.dk/Forms/R0710.aspx?id=126347; State Capital Injections in Financial Institutions Act of February 3, 2009 (commonly referred to as "Bank Package 2") available at https://www.retsinformation.dk/Forms/R0710.aspx? id=126348; Liquidation of Distressed Financial Institutions Act of June 1, 2010 (commonly referred to as "Bank Package 3"); Financial Business Act of September 23, 2010, https://www.retsinformation.dk/Forms/R0710.aspx?id= 133371). 
Questions

$2007 \quad 2010$

1. Does the FM have direct powers in prudential supervision? $0 \quad \begin{array}{lll}0 & 1\end{array}$

2. Does the FM appoint the majority of prudential authority $\begin{array}{lll}0.5 & 0.5\end{array}$ members?

3. Can the FM fire prudential authority members? $\quad 0 \quad 0$

4. Does the FM appoint the majority of supervisory authority $1 \quad 1$ members?

5. Can the FM fire supervisory authority members?

6. Does the FM appoint the majority of deposit insurance authority members?

7. Can the FM fire deposit insurance authority members? $\quad 1 \quad 1$

8. Is FM consent required for key prudential authority decisions?

9. Is FM consent required for key supervisory authority decisions?

10. Can FM reverse the decisions of prudential supervisors? $\quad 0 \quad 0$

11. Can FM issue rulemakings that affect prudential $\quad 0 \quad 0$ supervisors' decisions?

12. Is FM consent required for resolution of a qualified $\quad \begin{array}{lll}0 & 1\end{array}$ institution?

13. Is the resolution decision shielded from judicial review? $\quad 0 \quad 0$

14. Is FM involved in the resolution process? $\quad 0 \quad 1$

15. Is FM responsible for extending loans during the $\quad \begin{array}{ll}0 & 1\end{array}$ resolution?

\section{France}

Main reform laws: Loi 2010-76 du 21 janvier 2010 [Ordinance No. 201076, Jan. 21, 2010] Journal Officiel de la République Française [J.O.] [Official Gazette of France], Jan. 22, 2010, p. 27 (Fr.), available at http://legifrance. gouv.fr/affichTexte.do?cidTexte=JORFTEXT000021719945\& fastPos $=1 \&$ fast ReqId $=281956259$ \&categorieLien $=$ cid\&oldAction=rechTexte.

\begin{tabular}{|c|c|c|c|}
\hline & Questions & 2007 & 2010 \\
\hline 1. & Does the FM have direct powers in prudential supervision? & 0 & 0 \\
\hline & $\begin{array}{l}\text { Does the FM appoint the majority of prudential authority } \\
\text { members? }\end{array}$ & 0 & 1 \\
\hline 3. & Can the FM fire prudential authority members? & 0 & 0 \\
\hline
\end{tabular}




\begin{tabular}{lcc}
\hline \hline Questions & 2007 & 2010 \\
\hline $\begin{array}{l}\text { 4. Does the FM appoint the majority of supervisory authority } \\
\text { members? }\end{array}$ & 1 & 1 \\
5. Can the FM fire supervisory authority members? & 0 & 0 \\
6. Does the FM appoint the majority of deposit insurance & 1 & 1 \\
$\quad \quad$ authority members? & 0 & 0 \\
7. Can the FM fire deposit insurance authority members? & 0 & 0 \\
8. Is FM consent required for key prudential authority & & \\
$\quad$ decisions? & 0 & 0.5 \\
9. Is FM consent required for key supervisory authority & & \\
$\quad$ decisions? & 0 & 0.5 \\
10. Can FM reverse the decisions of prudential supervisors? & 1 & 1 \\
11. Can FM issue rulemakings that affect prudential & & \\
$\quad$ supervisors' decisions? & 0 & 0 \\
12. Is FM consent required for resolution of a qualified & & \\
$\quad$ institution? & 1 & 1 \\
13. Is the resolution decision shielded from judicial review? & 0 & 0 \\
14. Is FM involved in the resolution process? & 0 & 0 \\
15. Is FM responsible for extending loans during the & & \\
$\quad$ resolution? & 4 & 6 \\
\hline \hline$\quad$ Total & &
\end{tabular}

\section{Germany}

Main reform laws: Finanzmarktstabilisierungsgesetz [FMStG] [Financial Market Stabilization Act], Oct. 17, 2008, Bundesgesetzblatt, Teil I [BGBl. I] at 481982 (Ger.); Finanzmarktstabilisierungsergänzungsgesetz [FMStErgG] [Supplementary Financial Market Stabilization Act], Apr. 7, 2009, Bundesgesetzblatt, Teil I [BGBl. I] at 18725 (Ger.); Bankenrestrukturierungsgesetz [Bank Restructuring Act], Dec. 14, 2010, Bundesgesetzblatt, Teil I [BGBl. I] at 631900 (Ger.) (which includes, among others: Art. 1: KreditinstituteReorganisationsgesetz [Credit Institutions Reorganization Act], Art. 2: Kreditwesengesetz [KWG: Amendments to Banking Act], Art. 3: Restrukturierugsfondsgesetz [Restructuring Fund Act]).

\begin{tabular}{lcc}
\hline \hline Questions & 2007 & 2010 \\
\hline $\begin{array}{l}\text { 1. Does the FM have direct powers in prudential supervision? } \\
\text { 2. Does the FM appoint the majority of prudential authority }\end{array}$ & 0 & 0 \\
$\quad$ members? & 1 & 1 \\
3. Can the FM fire prudential authority members? & 0 & 1
\end{tabular}




\begin{tabular}{lcc}
\hline \hline Questions & 2007 & 2010 \\
\hline $\begin{array}{l}\text { 4. Does the FM appoint the majority of supervisory authority } \\
\text { members? }\end{array}$ & 0 & 0 \\
5. Can the FM fire supervisory authority members? & 0 & 0 \\
6. Does the FM appoint the majority of deposit insurance & 0 & 1 \\
$\quad \quad$ authority members? & 0 & 1 \\
7. Can the FM fire deposit insurance authority members? & 0 & 0 \\
8. Is FM consent required for key prudential authority & & \\
$\quad$ decisions? & 0 & 0 \\
9. Is FM consent required for key supervisory authority & & \\
$\quad$ decisions? & 0.5 & 0.5 \\
10. Can FM reverse the decisions of prudential supervisors? & 1 & 1 \\
11. Can FM issue rulemakings that affect prudential & & \\
$\quad$ supervisors' decisions? & 0 & 0 \\
12. Is FM consent required for resolution of a qualified & & \\
$\quad$ institution? & 0 & 0 \\
13. Is the resolution decision shielded from judicial review? & 0 & 0 \\
14. Is FM involved in the resolution process? & 0 & 1 \\
15. Is FM responsible for extending loans during the & & \\
$\quad$ resolution? & 2.5 & 6.5 \\
\hline \hline
\end{tabular}

\section{Ireland}

Main reform laws: Central Bank Reform Act 2010 (Act No. 23/2010) (Ir.) (amending certain provisions of the Central Bank Act 1942 (Act. No. 22/1942)), available at http://www.irishstatutebook.ie/1942/en/act/pub/0022/ index.html; Financial Services (Deposit Guarantee Scheme) Act 2009 (Act No. 13/2009) (Ir.), available at http://www.irishstatutebook.ie/2009/en/act/pub/ 0013/index.html; Central Bank and Credit Institutions (Resolution) Act 2011 (Act No. 27/2011) (Ir.), available at http://www.irishstatutebook.ie/pdf/2011/ en.act.2011.0027.pdf.

\begin{tabular}{lcc}
\hline \hline Questions & 2007 & 2010 \\
\hline $\begin{array}{l}\text { 1. Does the FM have direct powers in prudential supervision? } \\
\text { 2. Does the FM appoint the majority of prudential authority }\end{array}$ & 1 & 1 \\
$\quad$ members? & 1 & 1 \\
$\begin{array}{l}\text { 3. Can the FM fire prudential authority members? } \\
\text { 4. Does the FM appoint the majority of supervisory authority }\end{array}$ & 1 & 1
\end{tabular}




\begin{tabular}{|c|c|c|}
\hline Questions & 2007 & 2010 \\
\hline members? & & \\
\hline 5. Can the FM fire supervisory authority members? & 1 & 1 \\
\hline $\begin{array}{l}\text { 6. Does the FM appoint the majority of deposit insurance } \\
\text { authority members? }\end{array}$ & 1 & 1 \\
\hline 7. Can the FM fire deposit insurance authority members? & 1 & 1 \\
\hline $\begin{array}{l}\text { 8. Is FM consent required for key prudential authority } \\
\text { decisions? }\end{array}$ & 1 & 1 \\
\hline $\begin{array}{l}\text { 9. Is FM consent required for key supervisory authority } \\
\text { decisions? }\end{array}$ & 0 & 0 \\
\hline 10. Can FM reverse the decisions of prudential supervisors? & 0 & 1 \\
\hline $\begin{array}{l}\text { 11. Can FM issue rulemakings that affect prudential } \\
\text { supervisors' decisions? }\end{array}$ & 1 & 1 \\
\hline $\begin{array}{l}\text { 12. Is FM consent required for resolution of a qualified } \\
\text { institution? }\end{array}$ & 0 & 1 \\
\hline 13. Is the resolution decision shielded from judicial review? & 0 & 0 \\
\hline 14. Is FM involved in the resolution process? & 0 & 1 \\
\hline $\begin{array}{l}\text { 15. Is FM responsible for extending loans during the } \\
\text { resolution? }\end{array}$ & 0 & 1 \\
\hline Total & 9 & 13 \\
\hline
\end{tabular}

\section{Italy}

Main reform laws: No major reforms were introduced during the period studied in this Article.

\begin{tabular}{|c|c|c|}
\hline Questions & 2007 & 2010 \\
\hline 1. Does the FM have direct powers in prudential supervision? & 1 & 1 \\
\hline $\begin{array}{l}\text { 2. Does the FM appoint the majority of prudential authority } \\
\text { members? }\end{array}$ & 1 & 1 \\
\hline 3. Can the FM fire prudential authority members? & 0 & 0 \\
\hline $\begin{array}{l}\text { 4. Does the FM appoint the majority of supervisory authority } \\
\text { members? }\end{array}$ & 1 & 1 \\
\hline 5. Can the FM fire supervisory authority members? & 0 & 0 \\
\hline $\begin{array}{l}\text { 6. Does the FM appoint the majority of deposit insurance } \\
\text { authority members? }\end{array}$ & 0 & 0 \\
\hline 7. Can the FM fire deposit insurance authority members? & 0 & 0 \\
\hline $\begin{array}{l}\text { 8. Is FM consent required for key prudential authority } \\
\text { decisions? }\end{array}$ & 0 & 0 \\
\hline
\end{tabular}




\begin{tabular}{lcc}
\hline \hline Questions & 2007 & 2010 \\
\hline $\begin{array}{l}\text { 9. Is FM consent required for key supervisory authority } \\
\quad \text { decisions? }\end{array}$ & 0 & 0 \\
10. Can FM reverse the decisions of prudential supervisors? & 1 & 1 \\
11. Can FM issue rulemakings that affect prudential & 1 & 1 \\
$\quad$ supervisors' decisions? & 1 & 1 \\
$\begin{array}{l}\text { 12. Is FM consent required for resolution of a qualified } \\
\quad \text { institution? }\end{array}$ & 1 & 1 \\
13. Is the resolution decision shielded from judicial review? & 1 & 0 \\
14. Is FM involved in the resolution process? & 0 & 0 \\
15. Is FM responsible for extending loans during the & & \\
$\quad$ resolution? & 7 & 7 \\
\hline Total &
\end{tabular}

\section{Japan}

Main reform laws: No major reforms were introduced during the period studied in this Article.

\begin{tabular}{lcc}
\hline \hline Questions & 2007 & 2010 \\
\hline 1. Does the FM have direct powers in prudential supervision? & 1 & 1 \\
2. Does the FM appoint the majority of prudential authority & 1 & 1 \\
$\quad$ members? & 1 & 1 \\
3. Can the FM fire prudential authority members? & 1 & 1 \\
4. Does the FM appoint the majority of supervisory authority & & \\
$\quad$ members? & 1 & 1 \\
5. Can the FM fire supervisory authority members? & 1 & 1 \\
6. Does the FM appoint the majority of deposit insurance & & \\
$\quad$ authority members? & 0 & 0 \\
7. Can the FM fire deposit insurance authority members? & 1 & 1 \\
8. Is FM consent required for key prudential authority & & \\
$\quad$ decisions? & 1 & 1 \\
9. Is FM consent required for key supervisory authority & & \\
$\quad$ decisions? & 0 & 0 \\
10. Can FM reverse the decisions of prudential supervisors? & 1 & 1 \\
11. Can FM issue rulemakings that affect prudential & & \\
$\quad$ supervisors' decisions? & 1 & 1 \\
12. Is FM consent required for resolution of a qualified & &
\end{tabular}


Questions

$2007 \quad 2010$

13. Is the resolution decision shielded from judicial review? $\quad 0 \quad 0$

14. Is FM involved in the resolution process? $\quad 0 \quad 0$

15. Is FM responsible for extending loans during the $\quad 0 \quad 0$ resolution?

Total

$10 \quad 10$

Mexico

Main reform laws: No major reforms were introduced during the period studied in this Article.

\begin{tabular}{|c|c|c|c|}
\hline & Questions & 2007 & 2010 \\
\hline 1. & Does the FM have direct powers in prudential supervision? & 1 & 1 \\
\hline 2. & $\begin{array}{l}\text { Does the FM appoint the majority of prudential authority } \\
\text { members? }\end{array}$ & 1 & 1 \\
\hline 3. & Can the FM fire prudential authority members? & 1 & 1 \\
\hline 4. & $\begin{array}{l}\text { Does the FM appoint the majority of supervisory authority } \\
\text { members? }\end{array}$ & 1 & 1 \\
\hline 5 . & Can the FM fire supervisory authority members? & 0 & 0 \\
\hline 6. & $\begin{array}{l}\text { Does the FM appoint the majority of deposit insurance } \\
\text { authority members? }\end{array}$ & 1 & 1 \\
\hline 7. & Can the FM fire deposit insurance authority members? & 0 & 0 \\
\hline & $\begin{array}{l}\text { Is FM consent required for key prudential authority } \\
\text { decisions? }\end{array}$ & 1 & 1 \\
\hline & $\begin{array}{l}\text { Is FM consent required for key supervisory authority } \\
\text { decisions? }\end{array}$ & 0 & 0 \\
\hline 10. & Can FM reverse the decisions of prudential supervisors? & 0 & 0 \\
\hline 11. & $\begin{array}{l}\text { Can FM issue rulemakings that affect prudential } \\
\text { supervisors' decisions? }\end{array}$ & 0 & 0 \\
\hline 12. & $\begin{array}{l}\text { Is FM consent required for resolution of a qualified } \\
\text { institution? }\end{array}$ & 1 & 1 \\
\hline 13. & Is the resolution decision shielded from judicial review? & 1 & 1 \\
\hline 14. & Is FM involved in the resolution process? & 0 & 0 \\
\hline & $\begin{array}{l}\text { Is FM responsible for extending loans during the } \\
\text { resolution? }\end{array}$ & 0 & 0 \\
\hline & Total & 8 & 8 \\
\hline
\end{tabular}




\section{South Korea}

Main reform laws: No major reforms were introduced during the period studied in this Article.

Questions $2007 \quad 2010$

1. Does the FM have direct powers in prudential supervision? $0 \quad 0$

2. Does the FM appoint the majority of prudential authority $\quad 1 \quad 1$ members?

3. Can the FM fire prudential authority members? $\quad 0 \quad 0$

4. Does the FM appoint the majority of supervisory authority 111 members?

5. Can the FM fire supervisory authority members?

6. Does the FM appoint the majority of deposit insurance authority members?

7. Can the FM fire deposit insurance authority members? $\quad 0 \quad 0$

8. Is FM consent required for key prudential authority $\quad 0 \quad 0$ decisions?

9. Is FM consent required for key supervisory authority $\quad \begin{array}{lll}0 & 0\end{array}$ decisions?

10. Can FM reverse the decisions of prudential supervisors? $\quad 0 \quad 0$

11. Can FM issue rulemakings that affect prudential $\quad 0 \quad 0$ supervisors' decisions?

12. Is FM consent required for resolution of a qualified $\quad \begin{array}{lll}0 & 0\end{array}$ institution?

13. Is the resolution decision shielded from judicial review? $\quad \begin{array}{lll}0 & 0\end{array}$

14. Is FM involved in the resolution process? $\quad 0 \quad 0$

15. Is FM responsible for extending loans during the $\quad 0 \quad 0$ resolution?

\section{Spain}

Main reform laws: Royal Decree-Law 9/2009 (B.O.E. 2009, 10575) (Spain); Royal Decree 1642/2008 (B.O.E. 2008, 16384) (Spain).

Questions

$2007 \quad 2010$

1. Does the FM have direct powers in prudential supervision? 11

2. Does the FM appoint the majority of prudential authority $\quad \begin{array}{ll}1 & 1\end{array}$ members? 


\begin{tabular}{lcc}
\hline \hline Questions & 2007 & 2010 \\
\hline 3. Can the FM fire prudential authority members? & 0 & 0 \\
4. Does the FM appoint the majority of supervisory authority & 1 & 1 \\
$\quad$ members? & & \\
5. Can the FM fire supervisory authority members? & 0 & 0 \\
6. Does the FM appoint the majority of deposit insurance & 1 & 1 \\
$\quad$ authority members? & 0 & 0 \\
7. Can the FM fire deposit insurance authority members? & 1 & 1 \\
8. Is FM consent required for key prudential authority & & \\
$\quad$ decisions? & 0 & 0 \\
9. Is FM consent required for key supervisory authority & & \\
$\quad$ decisions? & 1 & 1 \\
10. Can FM reverse the decisions of prudential supervisors? & 0 & 0 \\
11. Can FM issue rulemakings that affect prudential & & \\
$\quad$ supervisors' decisions? & 0 & 1 \\
12. Is FM consent required for resolution of a qualified & & \\
$\quad$ institution? & 0 & 0 \\
13. Is the resolution decision shielded from judicial review? & 1 & 1 \\
14. Is FM involved in the resolution process? & 0 & 1 \\
15. Is FM responsible for extending loans during the \\
$\quad$ resolution?
\end{tabular}

\section{Switzerland}

Main reform laws: Bundesgesetz über die Eidgenössische Finanzmarktaufsicht [FINMASA] [Federal Financial Market Supervision Act] June 22, 2007, SR 956.1 (Switz.).

\begin{tabular}{crc}
\hline \hline Questions & $2007 \quad 2010$ \\
\hline
\end{tabular}

1. Does the FM have direct powers in prudential supervision? 00

2. Does the FM appoint the majority of prudential authority $\begin{array}{lll}1 & 1\end{array}$ members?

3. Can the FM fire prudential authority members? $\quad 0 \quad 0$

4. Does the FM appoint the majority of supervisory authority $1 \quad 1$ members?

5. Can the FM fire supervisory authority members? $\quad 0 \quad 0$

6. Does the FM appoint the majority of deposit insurance $\quad \begin{array}{ll}0 & 0\end{array}$ authority members? 


\begin{tabular}{|c|c|c|c|}
\hline & Questions & 2007 & 2010 \\
\hline 7. & Can the FM fire deposit insurance authority members? & 0 & 0 \\
\hline & $\begin{array}{l}\text { Is FM consent required for key prudential authority } \\
\text { decisions? }\end{array}$ & 0 & 0 \\
\hline & $\begin{array}{l}\text { Is FM consent required for key supervisory authority } \\
\text { decisions? }\end{array}$ & 0 & 0 \\
\hline 10. & Can FM reverse the decisions of prudential supervisors? & 0 & 0 \\
\hline & $\begin{array}{l}\text { Can FM issue rulemakings that affect prudential } \\
\text { supervisors' decisions? }\end{array}$ & 1 & 1 \\
\hline & $\begin{array}{l}\text { Is FM consent required for resolution of a qualified } \\
\text { institution? }\end{array}$ & 0 & 0 \\
\hline 13. & Is the resolution decision shielded from judicial review? & 0 & 0 \\
\hline 14. & Is FM involved in the resolution process? & 0 & 0 \\
\hline & $\begin{array}{l}\text { Is FM responsible for extending loans during the } \\
\text { resolution? }\end{array}$ & 0 & 0 \\
\hline & Total & 3 & 3 \\
\hline
\end{tabular}

\section{United Kingdom}

Main reform laws: Banking Act, 2009 c.1 (Eng.).

\begin{tabular}{lcc}
\hline \hline Questions & 2007 & 2010 \\
\hline $\begin{array}{l}\text { 1. Does the FM have direct powers in prudential supervision? } \\
\text { 2. Does the FM appoint the majority of prudential authority }\end{array}$ & 1 & 1 \\
$\quad$ members? & & 1 \\
3. Can the FM fire prudential authority members? & 0.5 & 0.5 \\
4. Does the FM appoint the majority of supervisory authority & 1 & 1 \\
$\quad$ members? & 0.5 & 0.5 \\
5. Can the FM fire supervisory authority members? & 0.5 & 0.5 \\
6. Does the FM appoint the majority of deposit insurance & & \\
$\quad$ authority members? & 0.5 & 0.5 \\
7. Can the FM fire deposit insurance authority members? & 0 & 0 \\
8. Is FM consent required for key prudential authority & & \\
$\quad$ decisions? & 0 & 0 \\
9. Is FM consent required for key supervisory authority & & \\
$\quad$ decisions? & 1 & 1 \\
10. Can FM reverse the decisions of prudential supervisors? & 1 & 1 \\
11. Can FM issue rulemakings that affect prudential & &
\end{tabular}




\begin{tabular}{lcc}
\hline \hline Questions & 2007 & 2010 \\
\hline 12. Is FM consent required for resolution of a qualified & 0 & 1 \\
$\quad$ institution? & & \\
13. Is the resolution decision shielded from judicial review? & 0 & 0 \\
14. Is FM involved in the resolution process? & 0 & 1 \\
$\begin{array}{l}\text { 15. Is FM responsible for extending loans during the } \\
\text { resolution? }\end{array}$ & 0 & 1 \\
\hline$\quad$ Total & 7 & 10 \\
\hline \hline
\end{tabular}

\section{United States}

Main reform laws: Dodd-Frank Wall Street Reform and Consumer Financial Protection Act, Pub. L. No. 111-203, 124 Stat. 1376 (2010) (to be codified in various sections of the U.S. Code).

\begin{tabular}{lcc}
\hline \hline Questions & 2007 & 2010 \\
\hline 1. Does the FM have direct powers in prudential supervision? & 0 & 1 \\
2. Does the FM appoint the majority of prudential authority & 0 & 0 \\
$\quad$ members? & 0 & 0 \\
3. Can the FM fire prudential authority members? & 0 & 0 \\
4. Does the FM appoint the majority of supervisory authority & & \\
$\quad$ members? & 0 & 0 \\
5. Can the FM fire supervisory authority members? & 0 & 0 \\
6. Does the FM appoint the majority of deposit insurance & & \\
$\quad$ authority members? & 0 & 0 \\
7. Can the FM fire deposit insurance authority members? & 0 & 0 \\
8. Is FM consent required for key prudential authority & & \\
$\quad$ decisions? & 0 & 0 \\
9. Is FM consent required for key supervisory authority & & \\
$\quad$ decisions? & 0 & 0 \\
10. Can FM reverse the decisions of prudential supervisors? \\
11. Can FM issue rulemakings that affect prudential \\
$\quad$ supervisors' decisions?
\end{tabular}




\begin{tabular}{ccc}
\hline \hline Questions & 2007 & 2010 \\
\hline Total & 0 & 4 \\
\hline \hline
\end{tabular}

APPENDIX II: QUESTIONNAIRE FOR LOCAL LAWYERS

From: Stavros Gadinis

Date: October 21, 2010

\section{Re: Data Regarding Reforms in the Supervision of the Banking and Securities Industry Following the 2008 Crisis}

The questionnaire below will help guide your research regarding postcrisis reforms in the jurisdiction you are studying. The goal of the project is to examine whether these reforms changed the allocation of authority between central banks, other administrative agencies (such as securities commissions), and central government entities (such as Treasury Departments/Ministries of Finance). Thus, we need to document the regulatory framework in each jurisdiction both before and after the crisis.

Please answer the questions in Parts A, B, and C below twice: both for the regime as it stood before the crisis, and for the regime as it stands after the crisis. To distinguish between the pre- and postcrisis reforms, the cut-off date will be April 30, 2007. Any reforms after that date will be categorized as postcrisis reforms. Currently, I have not set a final date for the project, in an attempt to capture reforms that are still ongoing.

\section{A. Prudential Supervision in the Banking Industry}

Prudential supervision of banks consists in regulators' efforts to confirm that the bank is not undertaking excessive risks in its regular lending operations. Regulators seek to assess the level of risk the bank is undertaking. Moreover, they examine whether the bank maintains sufficient capital to address these risks, whether the bank has in place the compliance systems, mechanisms, and dedicated staff that allows it to monitor these risks effectively, and more generally, whether the management of the bank is competent and trustworthy.

a. Which authority is responsible for the prudential supervision of banks? Is it a different authority for the holding company of a bank that is part of a corporate group (i.e. the consolidated entity)? 
b. Is there a different authority that is responsible for the day-today supervisory tasks (e.g. examinations, inspections, granting of various licenses or renewals, approving board elections, etc.)?

c. Describe the composition of these authorities. Please highlight the following:

i. How many members do these authorities have?

ii. Who appoints these members? For what term?

iii. Can a central government official (such as the President, Prime Minister, Minister of Finance/Secretary of the Treasury) fire these members at will?

d. Describe, briefly, the powers of these authorities. Please highlight the following:

i. Who approves the establishment of a new bank?

ii. Who oversees compliance with capital adequacy standards?

iii. Who decides whether a bank is undercapitalized?

iv. Can these authorities that the bank undertakes corrective action, if they see that it is undercapitalized, or otherwise exposed to excessive risks?

v. Is there any judicial review of these decisions?

e. Is there a framework for deposit insurance in this jurisdiction?

i. Which authority is responsible for administering the deposit insurance?

ii. Who appoints its members? For what term?

iii. Can a central government official (such as the President, Prime Minister, Minister of Finance/Secretary of the Treasury) fire these members at will?

f. Describe, briefly, the powers of central government officials (President, Prime Minister, Minister of Finance/Secretary of the Treasury) in prudential supervision. Please highlight the following:

i. Do they need to approve, consent to, or be consulted with regard to any of the decisions of the prudential supervisor(s)?

ii. Can they reverse any of the decisions of the prudential supervisor(s)? 
iii. Can they issue secondary legislative mandates, principles, or other mandatory rulemakings that can change prudential supervision?

iv. Can they intervene in how the prudential supervisors inspect a particular financial institution?

\section{B. Resolution Authority in the Banking Industry}

a. How does a bank go bankrupt? Does a regulatory authority declare a bank's bankruptcy?

i. Is this authority the same as the one responsible for prudential supervision? If different, please expand on its appointment and decision-making process (including its voting rules).

ii. Does it require a consultation with, or the consent of, another regulatory authority, or a central government official?

iii. Is there any judicial review of this decision?

b. Before declaring a bank's bankruptcy, are regulatory authorities required to explore whether there are any private sector solutions for the bank (i.e., a merger or a takeover by an otherwise healthy financial institution)?

c. Aside from bankruptcy, under what other conditions can a banking institution be ordered to liquidation? Which authority is responsible for this decision?

d. Who handles the resolution/liquidation?

i. Is it the same authority as above?

ii. Does it appoint an independent liquidator under its supervision, or does it handle the liquidation itself?

iii. Can any of the authorities above extend loans to the bank under liquidation, so that it can continue to operate for a certain period, in the hope that it will turn profitable in the short run?

e. What is the role of the deposit insurance fund in the liquidation process?

\section{Supervision of the Securities Industry}

a. Does this country have in place a regulatory framework for prudential supervision of securities firms and brokerage houses (e.g., capital adequacy standards, liquidity standards)

i. Who is responsible for setting the standards: the central government or a securities commission? 
ii. If a securities commission, please expand on the appointment and decision-making process for this commission.

iii. Who is responsible for the day-to-day supervision of securities firms' compliance with these standards? Is there a separate department handling this task?

b. Is there a separate regulatory framework for declaring the bankruptcy/liquidation of a securities firm?

i. Who is responsible for this task? Describe the decision-making process (e.g. voting rules, etc.).

D. Background Information for Reforms

a. When the financial crisis arose, authorities in each jurisdiction sought to deal with its impact. Were this country's authorities perceived as successful in their handling of the crisis? What was the coverage in the local press?

b. Who initiated proposals for reform? The government, the regulatory agencies, Congress/Parliament?

c. What was the view of the opposition party?

d. What was the view of affected interest groups (e.g., national bankers' association)? 